OPEN ACCESS

Edited by:

Maurizio Pesce,

Centro Cardiologico Monzino

(IRCCS), Italy

Reviewed by:

Sharan Ramaswamy,

Florida International University,

United States

Manuel M. Mazo,

University of Navarra, Spain

*Correspondence:

Peter Zilla

peter.zilla@uct.ac.za

Specialty section: This article was submitted to

Cardiovascular Biologics and

Regenerative Medicine,

a section of the journal

Frontiers in Cardiovascular Medicine

Received: 03 June 2020

Accepted: 28 July 2020

Published: 09 September 2020

Citation:

Zilla P, Deutsch M, Bezuidenhout $D$,

Davies NH and Pennel T (2020)

Progressive Reinvention or Destination Lost? Half a Century of Cardiovascular

Tissue Engineering.

Front. Cardiovasc. Med. 7:159.

doi: $10.3389 /$ fcvm.2020.00159

\section{Progressive Reinvention or Destination Lost? Half a Century of Cardiovascular Tissue Engineering}

\author{
Peter Zilla ${ }^{1,2 *}$, Manfred Deutsch ${ }^{3}$, Deon Bezuidenhout ${ }^{2}$, Neil H. Davies ${ }^{2}$ and Tim Pennel ${ }^{1}$ \\ ${ }^{1}$ Christiaan Barnard Division for Cardiothoracic Surgery, University of Cape Town, Cape Town, South Africa, ${ }^{2}$ Cardiovascular \\ Research Unit, University of Cape Town, Cape Town, South Africa, ${ }^{3}$ Karl Landsteiner Institute for Cardiovascular Surgical \\ Research, Vienna, Austria
}

The concept of tissue engineering evolved long before the phrase was forged, driven by the thromboembolic complications associated with the early total artificial heart programs of the 1960s. Yet more than half a century of dedicated research has not fulfilled the promise of successful broad clinical implementation. A historical account outlines reasons for this scientific impasse. For one, there was a disconnect between distinct eras each characterized by different clinical needs and different advocates. Initiated by the pioneers of cardiac surgery attempting to create neointimas on total artificial hearts, tissue engineering became fashionable when vascular surgeons pursued the endothelialisation of vascular grafts in the late 1970s. A decade later, it were cardiac surgeons again who strived to improve the longevity of tissue heart valves, and lastly, cardiologists entered the fray pursuing myocardial regeneration. Each of these disciplines and eras started with immense enthusiasm but were only remotely aware of the preceding efforts. Over the decades, the growing complexity of cellular and molecular biology as well as polymer sciences have led to surgeons gradually being replaced by scientists as the champions of tissue engineering. Together with a widening chasm between clinical purpose, human pathobiology and laboratory-based solutions, clinical implementation increasingly faded away as the singular endpoint of all strategies. Moreover, a loss of insight into the healing of cardiovascular prostheses in humans resulted in the acceptance of misleading animal models compromising the translation from laboratory to clinical reality. This was most evident in vascular graft healing, where the two main impediments to the in-situ generation of functional tissue in humans remained unheeded-the trans-anastomotic outgrowth stoppage of endothelium and the build-up of an impenetrable surface thrombus. To overcome this dead-lock, research focus needs to shift from a biologically possible tissue regeneration response to one that is feasible at the intended site and in the intended host environment of patients. Equipped with an impressive toolbox of modern biomaterials and deep insight into cues for facilitated healing, reconnecting to the "user needs" of patients would bring one of the most exciting concepts of cardiovascular medicine closer to clinical reality.

Keywords: cardiovascular tissue engineering, history, clinical needs, misleading animal models, refocusing translation 
"Once articles, particularly major reviews, appear that lack historical perspective of discovery, the wheel of reinvention perpetuates itself."

Julie Campbell

\section{INTRODUCTION}

After years of pioneering work in the 1950 (1-4), the breakthrough in cardiovascular surgery came a decade later with the ability to replace heart valves (5), repair aneurysms of the aorta (6), and bypass flow-limiting coronary artery stenoses (7).

Continual clinical progress has been made on the basis of better prosthetic materials, better designs and deeper insight into physiological needs. The gradual substitution of polyethylene terephthalate-based (PET) fabrics ("Dacron ${ }^{\circledR}$ ") (8) by expanded fine-fibrillar polytetrafluoroethylene (ePTFE) for medium-diameter grafts improved the patency of arterial prostheses in peripheral bypass surgery (9). Surface structuring $(10,11)$ seemed to improve the increasingly prohibitive thromboembolic limitations of total artificial hearts (TAH) (12, 13) and glutaraldehyde instead of formalin (14) crosslinking led to a significantly improved durability of bioprosthetic heart valves $(15,16)$.

By the 1970s, however, the initial belief that cardiovascular prostheses will continually improve began to wane. Pannus formation and thrombo-embolism thwarted the hope that total artificial hearts will make transplantation obsolete $(17,18)$; synthetic small diameter grafts had distinctly higher occlusion rates than vein grafts (19) and replacement heart valves either prematurely degenerated (20) or caused serious thromboembolic complications (21). It was the realization that no materialbased solution can ever match the non-thrombogenicity of the patient's own endothelium that gave rise to what was later called "tissue engineering". The unifying concept behind this undertaking was to replace diseased parts of the circulatory system with restorative implants which contained or regained the patient's own tissue in order to function like the non-diseased structures they replaced. As this concept integrates biological components with engineering principles and synthetic materials the term "tissue engineering" was coined around a "Keystone Meeting" in Colorado in the 1980s, 20 years after its principles were pioneered for the first time (22-24). For the present review this term will therefore be used for any approach that eventually leads to the creation of living and functional structures of the heart or the vasculature whether through in-vitro, invivo or combined procedures and as such stretches from single staged cell inoculation to bioreactor based concepts and from the decellularization of cardiovascular organ structures to their induced recellularization.

While tissue engineering soon evolved into an attractive concept for a broad spectrum of indications cardiovascular surgery deserves the distinction of having spearheaded both research and clinical translation for other disciplines.

\section{CLINICAL NEEDS: THEN VS. NOW}

The pioneers of tissue engineering in the 1960s and 1970s were surgeons experiencing the clinical needs first hand. Subsequently the dominance in the field tilted toward basic scientists. Given the fast changing ways cardiovascular surgery has been practiced during the past fifty years, however, this shift away from the surgeons inevitably led to a growing divergence between perceived and actual clinical needs for such implants.

\section{Original Needs for Tissue Engineering}

At the forefront of all tissue engineering efforts stood the pneumatically driven artificial heart. Caused by the dismal results of heart transplants in the pre-ciclosporin era (25), major total artificial heart (TAH) programs emerged globally based on an idea that had been pioneered by Willem Kolff's group in Utah in 1964 (12, 26-29). Apart from Salt Lake City, Houston was a hub for TAH research both at Baylor College and the Texas Heart Institute. Disappointingly, despite attempts to address thromboembolic complications through improved designs (13), the lack of blood-compatibility hampered the success of mechanical blood pumps well into their first longterm use almost 20 years later $(30,31)$. Therefore, in the absence of a paradigm-changing new immunosuppressive drug for transplantation, creating a living, non-thrombogenic surface lining on these blood pumps became a priority in the 1970 and beyond (10, 11, 22-24, 32-36).

In the 1980s, the critical need for prostheses containing functional tissue was in bypass surgery. There, the initial optimism for synthetic vascular grafts had given way to disillusionment. Mid-diameter ePTFE grafts in below-knee reconstructions had a $12 \% 4$-year primary patency in a major prospective multicenter study as opposed to $49 \%$ for saphenous vein grafts $(37,38)$. At the same time, coronary bypass surgery was at its peak as catheter interventions were still an experimental procedure. As arterial grafting was only performed by a handful of surgeons $(39,40)$, almost all coronary grafts were vein grafts. As a consequence, many of these patients had both their saphenous veins used. Since the 10 -year patency of coronary vein grafts is only $45 \%$ the reoperation rate in the absence of catheterbased interventions was as high as $14-18 \%$ (41). Therefore, with every $6^{\text {th }}$ patients needing a re-operation and often both saphenous veins having been taken due to previous procedures, there was a true, pressing need for synthetic small diameter conduits. Given the dismal results with ePTFE grafts in aortocoronary position [3-months patency 61\% (42)] endothelialised small-diameter grafts were the natural focus of tissue engineering efforts during this era.

A decade later, replacement heart valves were at a junction. Although repairing the mitral valve was already described in the late 1950s (43-45) and the aortic valve in the early 1960s (4648) repair-techniques took a back seat for decades to the easily reproducible insertion of a prosthetic device. Disappointingly, the long-term performance of these replacement valves was suboptimal, either due to complications with anticoagulation in mechanical valves or the fast degeneration of tissue valves in young and middle-aged patients. In the latter group, the 15year freedom from structural valve degeneration was as low as $31 \%$ (49). As such there was a pressing need for better performing replacement valves. The emphasis was on leaflet durability of "soft-leaflet" valves for adult patients who should avoid anticoagulation. 
Eventually, at the beginning of the new millennium, progress in bio- and material-sciences allowed to address the longstanding clinical need for myocardial regeneration. Although improved medical therapy had almost halved the death rate from heart failure between 1980 and 2000 it was still the leading cause of death in the Western world (only gradually being overtaken by cancer thereafter). Today, with more than 300,000 annual deaths in the USA alone (50)-in their majority due to ischemic heart disease and post-infarction heart failure-myocardial regeneration is the one condition that hasn't lost urgency for clinical tissue engineering solutions.

\section{Today's Needs for Tissue Engineering}

Over the decades, the clinical needs for tissue engineering solutions have changed. Some of them disappeared while others emerged.

In artificial hearts, for instance, positive displacement TAHs with their inverting diaphragms, big inflow cuffs, and prohibitive thromboembolic complication rates have been almost completely replaced by continuous-flow VADS with their equally-dimensioned in- and outflow conduits and active suction replacing passive diastolic filling. Stroke rates in second generation pumps were already down to $11 \%$ (51) at a time when Thoratec ${ }^{\circledR}$ the most popular ventricular assist device alone had crossed the 20,000 implant mark. Modern axial devices combined with antiplatelet therapy reached stroke rates of below $5 \%$ in spite of manifold longer implantation periods (52).

Even less needed than yesterday's diaphragm-driven total artificial hearts are small diameter vascular grafts for coronary bypass surgery. In today's era at least one-but increasingly morearterial grafts are being used in each patient. Together with the prevalence of catheter based interventions sufficient autologous grafts are available even in re-operations. Not as extreme but following a similar trend are lower limb revascularizations. By now, endovascular treatments have a nearly universal procedural success rate, low morbidity, and mortality, and with newer devices also improved patency rates. This makes them the recommended therapy of choice, particularly for TASC A-C lesions (Trans-Atlantic Inter-Society Consensus defining the staging of patients with peripheral arterial disease in relation to the expected superiority of either surgical or endovascular techniques). Only in critical limb ischemia (CLI) are surgical vein grafts still superior while prosthetic surgical grafts are associated with even poorer results than contemporary endovascular therapies. Therefore, angioplasty is also recommended as the preferred procedure in patients with CLI who lack an adequate vein conduit $(53,54)$. As such, the only remaining clinical need for tissue-engineered/regenerating vascular grafts may be for the small number of patients with critical limb ischemia, poor run-off and no saphenous veins available. But here, too, the previously occurring lack of saphenous vein conduits was mostly due to their prior use for coronary bypass grafts, something very unlikely to happen today. It is therefore a dwindling group of patients who would benefit from tissue engineered vascular grafts. Given the fast evolution of endovascular therapies such grafts would need to be based on thin-walled prostheses (55) used in covered stents to avoid that they are obsolete before finding their way into clinical practice. One indication for prosthetic medium-diameter grafts, however, has dramatically grown over the past decades: that for dialysis access grafts. Hardly any other indication saw such an increase in patient numbers from near negligible in 1980 to almost 3 million patients (56) presently being on dialysis globally. Although the Cimino fistula (57) has been the preferred way of creating a relatively longer-lasting access for dialysis puncture, it either prematurely fails or is not possible in a significant proportion of patients. Unfortunately, the alternatively used prosthetic access grafts have a particularly low patency due to thrombosis and neointimal hyperplasia. The primary patency for ePTFE is between 57 and $43 \%$ at 1-year and $29 \%$ at 2 years $(58,59)$. Therefore, no other vascular indication would benefit from a superior tissue-engineered graft more than dialysis access grafts - provided they not only achieve a surface endothelium but also control intimal hyperplasia.

In heart valves, needs have also changed over the decades. Transcatheter insertion has not only become an acceptable way of replacing diseased aortic valves (TAVI) in high risk patients but is by now the gold standard for the entire spectrum of patients from low- to high-risk (60). As trans-catheter valves are being crimped to small diameters for implantation they depend on crimpable soft-leaflets. Presently, these leaflets are made of bioprosthetic tissue but polymers or other foldable materials that can withstand the mechanical forces during the cardiac cycle are on the horizon (61). As contemporary bioprosthetic leaflets degenerate fast in younger patients (49), TAVIs are currently restricted to patients older than 70 years of age. Therefore, younger patients still receive surgically implanted mechanical heart valves with all their thromboembolic complications (62), even under optimal anticoagulation monitoring. As most of the contemporary TAVIs need the calcium deposits for anchorage they are additionally largely restricted to patients with aortic stenosis. As such, the two unresolved frontlines toward universal transcatheter heart valve replacements are stent designs that enable the replacement of both stenotic and regurgitant lesions and crimpable, anti-thrombotic, long-lasting leaflet materials. If both were synergistically resolved, a major clinical need for all non-repairable symptomatic patients younger than 70 years of age would be addressed. As a second field for tissue engineered heart valves, needs have grown in congenital cardiac surgery. The population of adults with congenital heart disease (CHD) has grown steadily. Having reached an estimated 1.3 million in the United States, adults with CHD are now more numerous than children and constitute $60 \%$ of the total CHD population (63). As much as growth is always emphasized as a main motivation for "living" heart valves in children, it is in fact also the longevity of the leaflets that dominates the needs. Growth does not play a major role on the left side of the heart as it is largely the annuli which are the size-restricting structure. For the aortic valve, this problem is addressed by the Ross procedure where a patient's own pulmonary valve is used as an autograft for replacing a diseased aortic valve while using an allograft for the biomechanically less strained pulmonary valve. Indications on the right side are those currently requiring homograftsfrom Ross procedures to Tetralogy of Fallot with pulmonary atresia; from truncus arteriosus to double-outlet right ventricle. 
Here, tissue engineered solutions would meet needs both at the original operation to avoid homograft failure after years and at the time previously implanted homografts fail and present for re-intervention. The latter would again be better served by a tissue-engineered trans-catheter solution as stenotic failed homografts typically lead to enlarged right ventricles that could add morbidity and mortality to the re-entry at open heart surgery. There is additionally a pediatric need for large tissue engineered patches for diameter augmentation of the aorta or the pulmonary artery/ies.

Although annual needs for replacement valves by far exceed a million patients $(64,65)$ and $>3$ million patients are in need of dialysis access, the highest number of patients potentially benefitting form a tissue engineering approach would still be those with congestive chronic heart failure (CHF). Over the decades, the number of patients with chronic heart failure has exponentially increased due to prolonged life expectancies and the progressive nature of cardiovascular diseases $(66,67)$. Today, more than 5 million patients are affected in the USA alone $(68,69)$. Their mortality is $>25 \%$ within the first year of diagnosis $(70,71)$. Chronic heart failure is a very serious disorder in children too, and one- third of the children die or receive a heart transplant in the first year after diagnosis (72). Heart transplantation as the ultimate treatment option for this growing group of patients cannot meet the needs leaving the replenishment of lost cardiomyocytes with the goal of structural and functional heart muscle repair as the only alternative to mechanical support.

Overall, while total artificial hearts and small diameter vascular grafts were the holy grail of tissue engineering at its outset today's needs are mid-diameter vascular grafts for dialysis access shunts, heart valves, and myocardial regeneration. Given the fact that first attempts to create functional, living tissue as part of a cardiovascular prostheses occurred more than 52 years ago, developments may again outpace progress resulting in the redundancy of a solution when it eventually fulfills clinical expectations.

\section{A HISTORY OF REITERATIONS}

Nothing epitomizes the slow progress of cardiovascular tissue engineering more than its reiterations over the course of half a century.

In order to generate functional, non-thrombogenic autologous tissue on cardiovascular prostheses, autologous cell inoculation was first reported by de Bakey's group in 1968 (73), the use of cell-culture techniques by Mansfield (74) in 1968 and Bernhard et al. (75) in 1969 and the induction of fall-out healing from circulating cells by Ghidoni in 1968 (76). The principles pioneered in these early days kept recurring over half a century. The reasons for the near de-novo rediscovery of similar basic approaches in 10 to 20 year cycles were manifold. One was certainly the fact that different interest groups in cardiovascular surgery discovered the potential of tissue engineering during different eras. Originally driven by artificial heart programs to address the frustration with a seemingly insurmountable thromboembolic complication rate in the 1960s and 1970s, vascular surgeons took over the baton in the 1980s and 1990s to improve the patency of small diameter grafts followed by cardiac surgeons resuming the lead again with a focus on prosthetic heart valves from the 2000s onwards overlappingly with the efforts of cardiologists and later engineers and material scientists to induce myocardial regeneration in the 2000s and 2010s. Each of these eras started with immense enthusiasm but was at best only remotely aware of the preceding efforts. Another reason for the cyclic rediscovery of tissue engineering for different cardiovascular prostheses was the lack of break-throughs leading to a true change of clinical practice. Had the early efforts led to a stable non-thombogenic endothelial lining of artificial hearts, both small diameter vascular grafts and prosthetic heart valves would have been pursued in continuity building on the previous developments. Moreover, as Julie Campbell put it (77), once articles, particularly major reviews, appear that lack historical perspective of discovery, the wheel of reinvention perpetuates itself.

\section{SUCCESSES AND FAILURES}

Over the decades, principles have not much changed but reemerged under different names. What did, however, genuinely change was our understanding and interpretation of the biological processes involved. Circulating progenitor cells, homing mechanisms and trans-differentiation have gained traction over phenotypical determination, mass-harvest and mass-culture. The perhaps biggest impact had the recognition of trans-differentiation, a pathway that was still highly contested in the 1970s (78). The concept was an affront to the eminent paradigm of lineage-based developmental biology by which cells reach a terminally differentiated state. Its impact was felt in early vascular tissue engineering. The "purity" of cultured endothelial cells (79) for instance, was seen as key to the clinical success of vascular graft endothelialisation as "contaminating" smooth muscle cells were assumed to be the nucleus of occlusive intimal hyperplasia. It took long-term clinical explants to disprove this paradigm. The clinically implanted "pure" endothelial monolayers had in fact developed into a neo-artery structure with mature, contractile smooth muscle cells underneath the endothelium, separated by a well-developed internal elastic membrane (80). As trans-anastomotic outgrowth and transmural ingrowth could be excluded in these grafts the two likely retrospective explanations are either homing of circulating cells or trans-differentiation of the originally implanted cells. Since then, the immensely promising field of stem cell and progenitor cell (trans)-differentiation opened the door to a new era with post-lineage trans-differentiation being equally exciting. There, trans-differentiation from adipocytes into epithelial cells (81), fibroblasts into endothelial cells (82) and vice versa endothelial cells into fibroblasts $(83,84)$ has been demonstrated. Yet, macrophages hold center-stage in this field, having been shown to transition into fibroblasts $(85)$, myofiboblasts $(86,87)$, and vascular smooth muscle cells (88-91). The boundary between stem cell / progenitor cell differentiation and post lineage 
trans-differentiation is still blurred as the role of circulating monocytes as endothelial progenitor cells underscores (92). The acknowledgment of trans-differentiation went hand in hand with that of the role of biomechanics (93). Its recognition as a main regulator of intimal hyperplasia in vein grafts on the tissue level (94-98) was as important as that on a cellular level where mechano-transduction for instance proved to be key to the differentiation of stem-cells and progenitor cells (99-101). Vein graft intimal hyperplasia highlighted the potentially detrimental effect on the clinical performance of tissue engineered implants if the biomechanics-including shear forces-deviate from the needs of the destination site $(94-98,102)$. Similarly, changes in substrate stiffness had been shown to lead to stem cells differentiating toward different lineages (103) providing one of many potential explanations for e.g., tissue engineered heart valves ending up with fibrosing and shrinking leaflets instead of delicate tri-layered replicas of nature $(104,105)$ or insufficient remodeling of vascular grafts (106).

As none of the tissue engineering approaches of the past 52 years led to a change in clinical practice they reflect half a century of disappointment and only partially fulfilled promises. While each individual concept had specific issues (lack of continuity; too low a cell inoculum; too slow or too fast scaffold degradations; biomechanical incompatibilities or remnant immunogenicity) one single root-failure in the clinical translation can be identified as a common thread: the refusal to accept or recognize that the trans-anastomotic healing mode that leads to successful in-situ endothelialisation in animal models is wholly irrelevant in man.

\section{COLLECTIVE COMPLICITY}

As much as modern laboratory science allows to answer many questions in-vitro, the peculiar healing characteristics of cardiovascular implants in man make animal implants unavoidable. While animal models cannot fully emulate the human situation in general, the ones used for cardiovascular implants have been particularly unsuited to provide accurate pre-clinical feed-back. As such, they were and still are the main obstacle to the clinical translation of cardiovascular tissue engineering. In animal research, it does make a difference whether a well-considered model for clearly defined questions can still only partially provide appropriate answers or if a broadthough unwitting-consensus prevails to use established animal models out of convenience, skills- and cost reasons regardless of the fact that the gap to the clinical reality is unbridgeable.

In humans, trans-anastomotic endothelial outgrowth plays no role as it does not exceed more than a few millimeters even after years of implantation (102, 107-109) (Figures 1, 2). As such, it is evident that in patients, any in-situ tissue engineering approach would need to harness either transmural endothelialisation or fall-out healing. Yet, by choosing short graft lengths in rapidly endothelializing animal models, implants were often trans-anastomotically fully endothelialised by the time of explantation (102, 110) (Figures 1, 2). This was aggravated by the fact that in over $90 \%$ of large animal studies the average graft length was $<5.5 \mathrm{~cm}$ (102). Taken into consideration that ingrowth occurs from two anastomotic sites the de facto graft length was $2.8 \mathrm{~cm}$ in animal models where the trans-anastomotic outgrowth is a few centimeters per month! To put it into perspective: the same outgrowth distance which takes 56 weeks in humans before it comes to a complete stop is reached after 3.5 weeks in dogs and significantly earlier in other species (102). Although it is understandable that abandoning wellestablished models would have been highly disruptive from the standpoint of implantation skills and laboratory-specific data histories, this system-immanent hurdle to the clinical translation of tissue engineering is also potentially dangerous when it comes to misleading preclinical results that may prompt premature clinical trials.

\section{LIMITS OF ENGINEERED TISSUE REGENERATION IN HUMANS}

The in-vivo population of scaffolds with host tissue is a critical component of tissue engineering whether or not cells were already incorporated at the time of implantation. Naturally, cellfree implants rely entirely on the in-vivo in-growth or outgrowth of host tissue. Given the crucial role of this process it is puzzling how underappreciated the question remained whether the presumed mode of "healing" can be expected to successfully occur in humans.

After half a century of a de-facto focus on the largely irrelevant surface outgrowth of tissue across the anastomoses, experimental data will need to have answered three questions before they can be assumed to succeed in their clinical translation: (a) was an experimentally demonstrated tissue regeneration mode likely to happen at the intended clinical site; (b) is the successful population of an implant with all functional tissue components likely to happen in humans before the build-up of adverse ingrowth conditions and (c) in the case of degradable scaffoldscan functional tissue formation be completed before the scaffold starts disintegrating.

Although experimental models that excluded transanastomotic endothelialisation were proposed $>35$ years ago when Hess et al. (111) suggested a looped conduit that enables the implantation of graft lengths of up to $10 \mathrm{~cm}$ in the infrarenal aorta of the rat they remained in obscurity until recently (110, 112, 113) (Figures 2, 3).

Of all modes of cell population, facilitated fall out healing from the circulation would be the holy grail of tissue regeneration. It is therefore surprising that not more efforts had gone into clarifying the true potential of this healing mode. Again first described by DeBakey's group in Houston in $1963(109,114)$ and clinically confirmed by Berger and Sauvage at the University of Washington in the early 1970s (107) "fall out" endothelialisation had been sporadically observed thereafter both on artificial hearts (35) and on vascular grafts $(113,115-121)$. Key to being able to observe true "fall-out" healing without interference from either trans-anastomotic or trans-mural ingrowth, however, are double isolation models that clearly distinguish it from all other possible regeneration modes both from the adventitia and the anastomotic side. It mystifies that isolation models capable of 

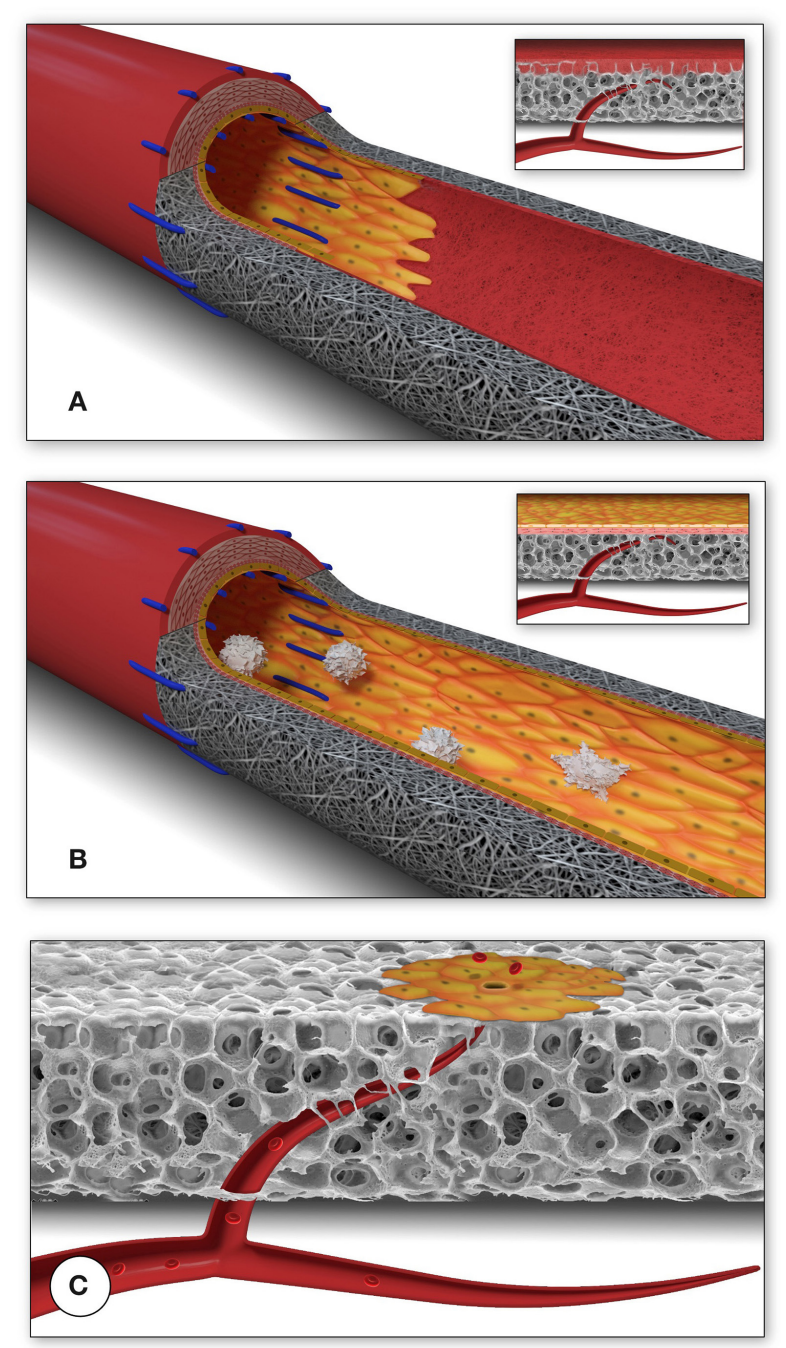

FIGURE 1 | Schematic presentation of the fundamental difference in cellularization and healing of prosthetic cardiovascular implants in humans (A) and in animal models (B). In humans, transanastomotic outgrowth hardly exceeds a few millimeters even after years of implantation. Continual fibrinogen and platelet replenishment from the blood leads to a compacted surface thrombus in the luminal interstices of the scaffold that increasingly becomes hostile toward capillary penetration similar to the wall thrombus of aneurysms. Over time, this compacted acellular material in the luminal layers of a scaffold becomes prohibitive for transmural endothelialisation (Insert A) even if scaffold structure and/or degradability would facilitate capillary penetration. The rapid trans-anastomotic outgrowth of adjacent endothelium and its subintimal cells in the vast majority of animal models (B) also mitigates transmural vascularization (Insert B) while actively recruiting cells from the circulation. As such, the entire healing pattern in most animal models from surface endothelium to intramural cell population is non-predictive for the tissue response in patients. For transmural endothelialisation to be successful (C), models need to be chosen where the presence of a surface endothelium is not pre-empted. Only this allows to study the antagonistic dynamics between ingrowth spaces, accelerated angiogenesis and the build-up of increasingly impenetrable, compacted thrombus in the luminal interstices of a scaffold.

achieving this periodically emerged over the past four decades $(87,111,113,117)$ without enthusing the countless groups that would have needed this healing mode for the validation of their

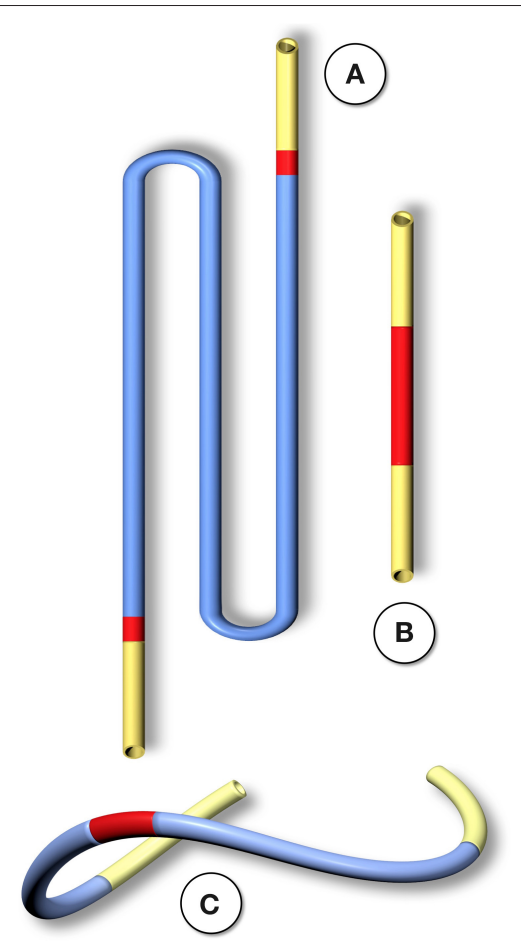

FIGURE 2 | Schematic comparison of graft lengths typically used for clinical peripheral bypass grafts (A) and experimental grafts implanted in animals (B). In $>90 \%$ of all large animal experiments grafts were shorter than $6 \mathrm{~cm}$. In most animal models, trans-anastomotic endothelial outgrowth (red) leads to complete surface endothelialisation within weeks making it impossible to study transmural or blood-born endothelialization. In clinically implanted bypass grafts, in contrast, ingrowth stoppage permanently leaves over $90 \%$ of the graft non-endothelialized (blue). Therefore, animal studies generally investigate a mode of surface endothelialization that is irrelevant in humans. To study transmural- or fall-out endothelialisation from the blood stream experimental grafts need to be welded between sufficiently long low-porosity grafts to clearly see a non-endothelialized zone between the progressing margins of transanastomotic outgrowth and endothelium originating from the investigated mid segment (C). From (102) with permission.

tissue engineering concepts. Almost 40 years ago-also in the context of artificial heart research-Feigl et al. already used such a double-isolation model to unambiguously prove in large animals that facilitated surface entrapment of circulating mononuclear cells can lead to their differentiation into a neo-vessel structure containing myofibroblasts and endothelial cells within a PET scaffold (87). Most recently, the occurrence of fall-out healing was again confirmed in a murine loop-graft isolation- and sealing-model (Figure 3) which did reemphasize how minor the contribution of this healing mode is to surface endothelialisation as opposed to transmural endothelialisation (113).

Thus, in the absence of any foreseeable breakthrough with facilitated "fall out" healing in the near future, transmural endothelialisation will remain the only likely avenue to a successful clinical in situ endothelialisation particularly of synthetic cardiovascular prosthesis. Key to this healing mode first described in 1962 (122) is the penetration of the full wall thickness of an implant by sprouting adventitial capillaries. These tubes were shown to coalesce with the graft lumen 


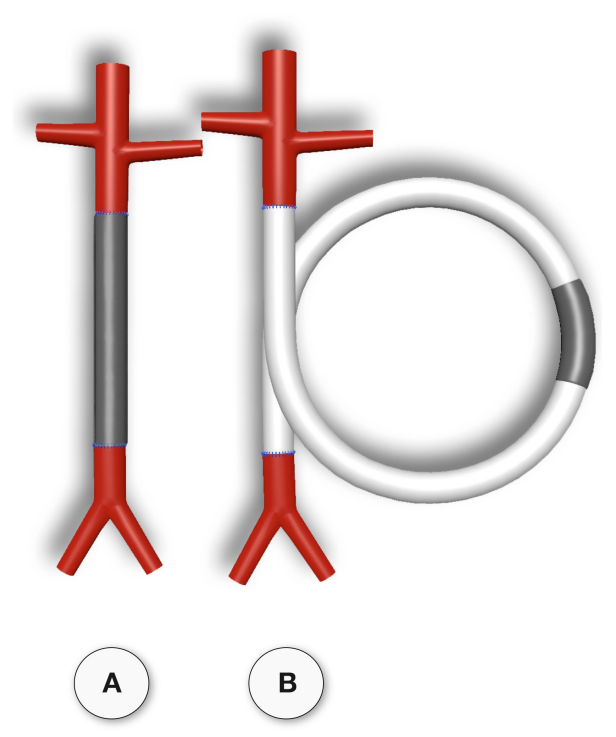

FIGURE 3 | Typical straight infra-renal interposition graft in rats usually \pm $10 \mathrm{~mm}$ in length (A) and loop graft of $\pm 100 \mathrm{~mm}$ length with an experimental segment welded into the mid-region of low-porosity ePTFE (B). While straight infrarenal interpositions usually lead to.trans-anastomotic endothelialisation before trans-mural ingrowth can occur the "isolation" segments in the loop graft enable the investigation of transmural endothelialisation without interference from transanastomotic endothelialisation. By also sealing the interposition segment against the adventitia, a model for fall-out healing is created. From (110) with permission.

on the blood surface $(113,123-125)$ where they give rise to expanding endothelial islands $(102,113)$ (Figures 4, 5). Not only do these transmural vessels largely maintain continuity with the abluminal side $(123,127)$, they are also likely to attract other cell types required for the complete tissue integration of the scaffolds. As Patricia d'Amore had already concluded in the 1990s undifferentiated mesenchymal cells may follow these endothelial tubes and be directed by them in their differentiation into SMCs (128). Although facilitating circumstances such as endothelial-rich peri-graft tissues were shown to potentially augment transmural endothelialisation (129-131) the scaffold itself must allow this process by providing continual, ingrowthpermissible spaces (102).

Under clinical circumstances, however, transmural endothelialisation is not only determined by ingrowth spaces but also by two interdependent in-situ responses distinctive to humans: the near absence of trans-anastomotic endothelialisation (Figure 2) and the resulting gradual buildup of impenetrable thrombus near the blood surface over time (Figures 5-7). While trans-anastomotic outgrowthinhibition has been a well-known phenomenon for the past 60 years (107) the detrimental effect of the resulting surface thrombus-compaction on transmural tissue ingrowth has only slowly emerged. Observed from the 1960s onwards (102, 107$109,115,116,132,133)$ this acellular dense fibrin layer building up in the interstices of synthetic vascular grafts near their non-endothelialised blood surfaces was initially thought to be

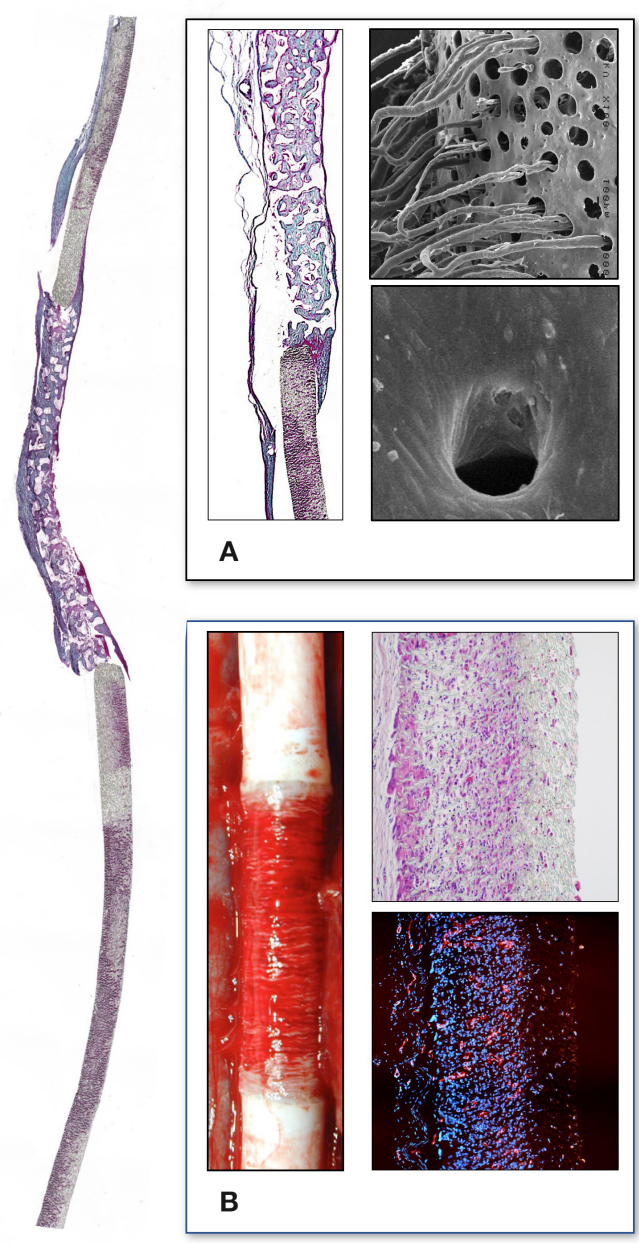

FIGURE 4 | Interposition isolation models for studying endothelialisation without the interference of trans-anastomotic endothelial out- and over-growth. (A) Rat infra-renal loop graft model. A high porosity polyurethane graft was welded into the mid-segment of an up to $100 \mathrm{~mm}$ long low-density ePTFE graft. The confluent mid-graft endothelium reached onto the otherwise endothelial-free ePTFE sections. Transmural ingrowth from the adventitial side was confirmed with corrosion casting. The origin of the surface endothelium was sometimes traceable to capillary openings on the blood surface. (B) Senescent baboon femoro-femoral isolation graft model. Experimental grafts were equally welded into the mid-section of low-porosity ePTFE. The experimental ePTFE graft shown possessed a dense middle layer which made it impenetrable for cells. After 6 weeks, cellularity was almost exclusively on the adventitial side, highlighting that trans-mural ingrowth from the adventitia overwhelmingly accounts for the cell population of the graft wall unless actively recruited by transanastomotic endothelium (see Figure 6). From (113) and (102) with permission.

PET related $(109,134,135)$. Yet, resembling the almost acellular "anion-layer" thrombi of aneurysms (136) comparative primate studies in the 1980s already suspected the platelet-rich, dense fibrin itself to be the culprit (135). Subsequent insight into the diversity of thrombus formation eventually provided some explanations in the 1990s (137). While a typical "wound healing type" fibrin with its relatively low fiber density and thick fibers strongly stimulates angiogenesis (Figure 7C) the high-density 


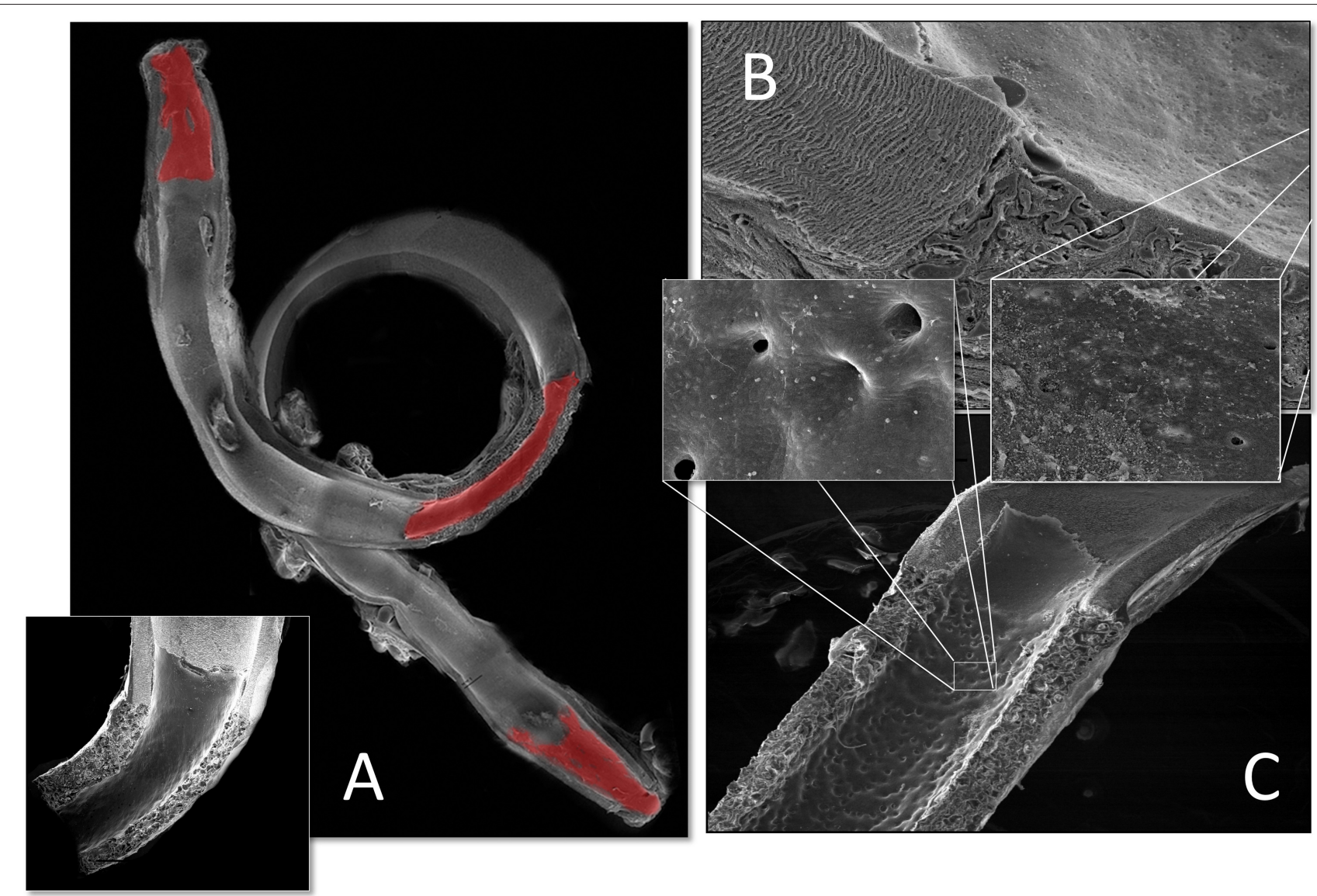

FIGURE 5 | Transmural endothelialisation of vascular grafts in the rat (A) and the senescent baboon (B,C). The loop graft in the rat (A) shows clearly discernible edges of the trans-anastomotically outgrowing endothelium (post-colored in red) from the infra-renal aorta with a long stretch of endothelium-free surface separating it from the trans-mural mid-graft endothelium (also post-colored in red). The presence of a long separating zone between the experimental graft and the transanastomotic outgrowth-edge is even more important in view of transanastomotic outgrowth also occurring in the opposite direction (Insert A) from the experimental graft in case of successful trans-mural endothelialisation. (B,C) Similar isolation graft in femoro-femoral position in the senescent Chacma baboon. After 6 weeks, transmural sprouting had either successfully led to confluent surface endothelialisation (C) with multiple capillary openings (Insert C) or in its absence led to the build-up of a dense fibrin matrix in the interstices near and on the surface (B). Sometimes sporadic small endothelial islets are detectable (Insert B).

mat of thin fibers precipitating in a fibrinogen rich environment like the one near the surface of cardiovascular implants is more thrombogenic (133) and inhibits capillary formation (138) (Figures 5B, 6C, 7A,B). As such, complete transmural healing needs to be concluded before this barrier builds up (102). As was shown in an isolation model in a non-human primate $(102,126)$ non-facilitating circumstances may allow some individuals to successfully conclude transmural endothelialisation before the build-up of hostile surface thrombus while in others sprouting capillaries already hit a barrier (Figure 6C). The focus of engineered tissue regeneration efforts must therefore be to temporarily block the build-up of impenetrable interstitial thrombus near the blood surface while facilitating accelerated transmural endothelialisation.

\section{A PROTRACTED EVOLUTION}

Comprising the experience of more than five decades, concrete tissue engineering approaches ranged from direct cell inoculation to bioreactor-based in-vitro culture; from decellularization of natural tissues to purely synthetic concepts; from degradable fabrics to injectable scaffolds and from facilitated ingrowth to inadvertent outgrowth. As these sometimes novel and at other times reiterated strategies emerged over more than half a century, a systemic classification never materialized. Yet, the clearest overarching order seems to be one that distinguishes between "vital" and "non-vital" implants.

\section{Vital Implants}

\section{Single-Stage, Direct Inoculation of Autologous Cells, or Tissue}

Naturally, the inoculation of prostheses with autologous cells at the time of surgery represented the first step toward "living" implants.

Given the insurmountable thromboembolic complications of artificial hearts and the conclusion of deBakey et al. (109) and Wesolowski et al. (108) in 1964 that prosthetic blood surfaces remain non-endothelialised in humans it was foreseeable 

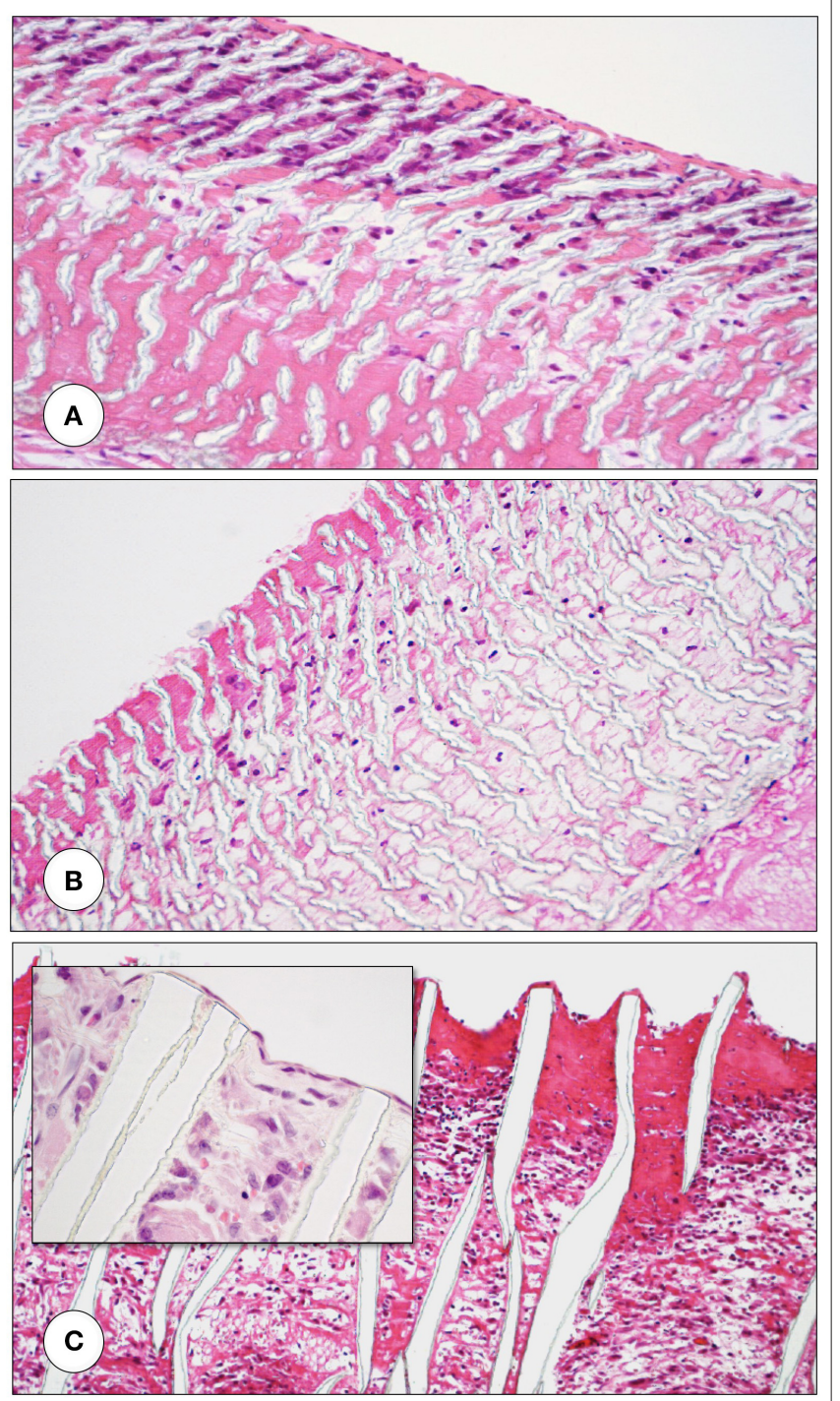

FIGURE 6 | Femoro-femoral isolation model in the Chacma Baboon (6 weeks) $(102,126)$. The wrapped, ingrowth-preventive $30 \mu \mathrm{m}$ ePTFE segements [(A) near anastomosis with trans-anastomotic endothelial outgrowth; (B) beyond trans-anastomotic endothelium with compacted surface thrombus)] had a high-porosity $150 \mu \mathrm{m}$ IND experimental ePTFE graft [(C) and Insert] welded into the mid-section. The low-porosity, wrapped isolation segments highlight the need for the presence of an endothelium for the active recruitment of largely mononuclear cells from the blood stream (A,B). The very-high porosity isolated mid-graft segment showed either dense, compacted thrombus in the internodal spaces of the luminal side (C) or well-healed grafts with fully trans-murally endothelialized blood surfaces (insert C).

that first efforts toward tissue incorporation would be made at leading centers for artificial heart research. Accordingly, it was Ghidoni of deBakey's group who inoculated fragments of autologous skeletal muscle into the velour lining of left ventricular bypass pumps leading to foci of proliferating spindleshaped cells but no endothelium after 2 weeks (139) - the longest possible implantation period before these early pumps failed. The attached tissue stripes sowed central necrosis and the concept was abandoned in favor of using cultured cells.
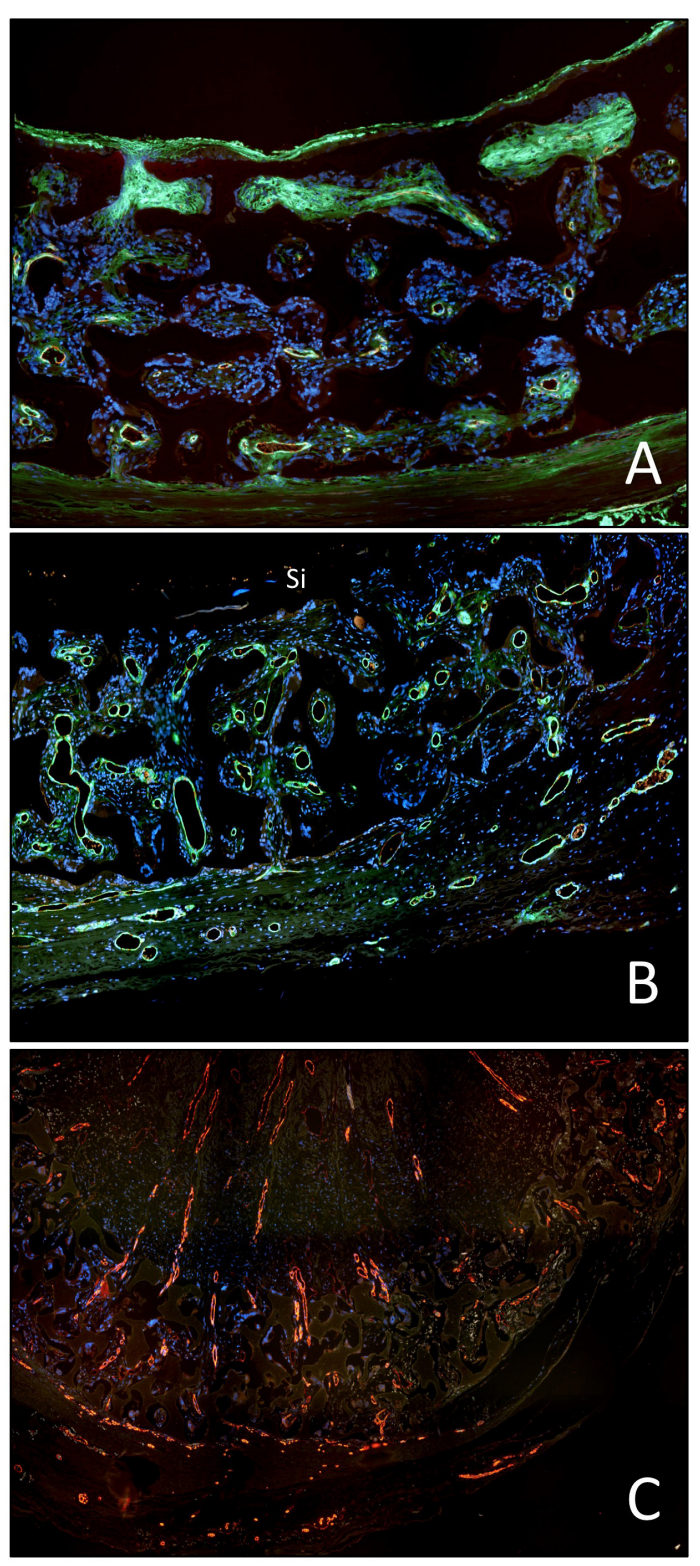

FIGURE 7 | Demonstration of the detrimental effect of the compacted, dense surface thrombus on transmural endothelialisation in the baboon femoro-femoral isolation model (identical implant periods in A to C). (A) Restriction of transmural vessel ingrowth to the outer half of the graft in the presence of a compacted surface thrombus in the interstitial spaces of the luminal third of the graft wall. (B) Identical mid-graft with a sealing, oxygen-permissible silicon membrane on the blood surface. The transmural vessel ingrowth reaches through the entire wall thickness. (C) Identical graft as in A but occluded. The long-distance outgrowth of trans-mural blood vessels through the graft wall and the entire thrombus highlights the fact that fibrin clots are pro-angiogenic unless they become compacted near the blood surface as typically seen in non-endothelialised vascular grafts in humans.

Fifteen years later, Mid-Western vascular surgeons from Indianapolis (140) and Ann Arbor (141) took up the idea of autologous single-stage cell inoculation and applied it to Dacron prostheses calling it "Endothelial Cell Seeding." In 
dogs, seeding of venous endothelial cells successfully generated a mid-graft endothelium (141). Yet, when carried over into clinical trials, venous endothelial cell-seeding failed to achieve any improvement to the patency of the up to $60 \mathrm{~cm}$ long, medium-diameter ePTFE prostheses used for femoro-popliteal bypass grafts (142). It became obvious that seeding densities were too low, aggravated by a reduced reproductive capacity of endothelial cells in smokers (143-145) and patients with hyperlipidaemia $(146,147)$ - two conditions present in the vast majority of patients. Attempts to increase harvest efficiencies by using microvascular endothelial cells from adipose tissue $(148,149)$ or bone marrow $(150,151)$ again led to the successful creation of a functional endothelium in animal experiments (151-153). Yet, microvascular seeding raised concerns regarding unrestricted subendothelial proliferation (154) and when it was eventually clinically tested it also showed no significant improvement over controls (155). Typical for tissue engineering in general, single-staged seeding was rediscovered 25 years after it was first described $(156,157)$ and by a few researchers is still carried over into the present time (158-161). The main novelty was the replacement of the bio-stable PET and PTFE scaffolds by bio-degradable materials (156). Using again bone marrow as a cell source the concept was experimentally tested in vascular grafts in dogs (151), sheep (162), pigs (163), and mice (160) followed by a clinical pilot study in children (157). When seeded tube grafts were implanted as extracardiac total cavo-pulmonary connections (TCPC) significant graft stenoses developed in more than a quarter of all patients $(159,164)$. Experimental work suggested that higher seeding densities may mitigate graft stenosis $(160,161)$. Alternatively, pharmacological interventions were tested emulating the previously tried ACE inhibitor therapy (165) with modern angiotensin II receptor blockade (166). Eventually, single stage seeding of degradable scaffolds was carried over to heart valves and tested in acute (167) and semi-acute (168) sheep implants. Like 37 years before (140), cells were embedded in a fibrin matrix deep within the polymeric meshwork at the time of implantation. When bone marrow cells were seeded on supramolecular polymers, long term results were discouraging with valves failing due to tissue overgrowth and leaflet fusion (158). When the same scaffolds were used as unseeded valves, results were significantly better (158).

Eventually, the ultimate exploit of single-staged cell inoculation was in myocardial regeneration where it endured the longest. This was partly because the clinical drivers were not surgeons and as such least likely to have been exposed to the disappointing previous efforts. At the same time, the enthusiasm for single-staged myocardial cell inoculation was certainly also carried by its concurrence with the early days of stem cell research and the accompanying fascination with the potential of these cells. Early experimental reports describing startling myocardial regeneration in mice after MI (169) triggered a global stampede toward myocardial regeneration work resulting in clinical trials being reported within a year $(170,171)$ just to be thoroughly disproven 2 years later (172). Fifteen years after the first gung-ho period, meta-analyses of clinical trials with adult stem cells still showed conflicting results ranging from minimal to no therapeutic benefits $(173,174)$. The greatest shortcoming of the initial approach was the naïve misconception of myocardium as a gel-like structure rather than the dense sponge which particularly the venous side of the vasculature constitutes. As such, rather than engrafted, the injectates were largely washed out and the few remaining cells did not find a matrix environment to survive (175). Recent approaches toward defeating this Achilles heel have been the alternative use of compact $100 \mu \mathrm{m}$ thick myocardial muscle bundles grown from human induced pluripotent stem cells (hiPSC) (176) or human embryonic stem cells (hESC) (177) or the injection of large cell agglomerates in form of "micro tissue" spheres $(178,179)$ (Figure 8) and the use of injectable biomaterial scaffolds to entrap and nurture the cells after delivery which has started to achieve incremental improvements $(181,182)$. Apart from embedding transplanted cells in a matrix that contains engraftment and pro-angiogenic cues, the second benefit of injecting such gels into myocardial infarcts is as a space-holder arresting an otherwise deleterious downward spiral of remodeling $(183,184)$ (Figure 9). Moreover, the initial hope to facilitate the trans-differentiation of progenitor cells to cardiomyocytes has given way to a more modest expectation allowing for anti-fibrotic and anti-inflammatory outcomes on the basis of a paracrine effect regardless of the cell types inoculated (188). In a translation context, exploiting the components of a paracrine mechanism, particularly exosomes is attractive due to reduced regulatory requirements and their off-the-shelf nature (189). Notwithstanding, the efficacy of this approach will again rest on efficient delivery perhaps most likely through controlled release from injectable scaffolds or sophisticated targeting approaches (190).

In hindsight, the trajectory of myocardial regeneration, however, hasn't been different from other areas of cardiovascular tissue engineering. Although much basic knowledge had been gained in the three preceding decades, this latest embodiment of the earliest approach to tissue engineering repeated many of the mistakes and equally fell for the temptations of its predecessors: hype at the beginning rather than thorough basic research; premature translations into clinical procedures; the unbridled belief in stem cells alone ignoring the embedding environment, the need for neo-angiogenesis and the importance of biomechanics and the resulting push-back by public opinion. The latter was highlighted by the inability of the first sufficiently powered phase III clinical trial to achieve clarity with respect to bone marrow derived cells (BAMI) to recruit more than $12.5 \%$ of required patients (189). Like with other fields of cardiovascular tissue engineering, the short-cut temptation single staged cellinoculation held may also have slowed down the clinical realization of "true" engineering approaches in myocardial regeneration. Promising developments from myocardial muscle bundles to micro-tissue spheres would have otherwise seen a much more proactive clinical translation. Given the clinical need for a successful solution, the current "death-valley" will need to be crossed with determination and in the absence of glory. While acceptance of the complexity of the pathobiology involved has been a first step toward a more scientific approach, the issue of misleading animal models also hampers success in this area of cardiovascular tissue engineering. As convenient 


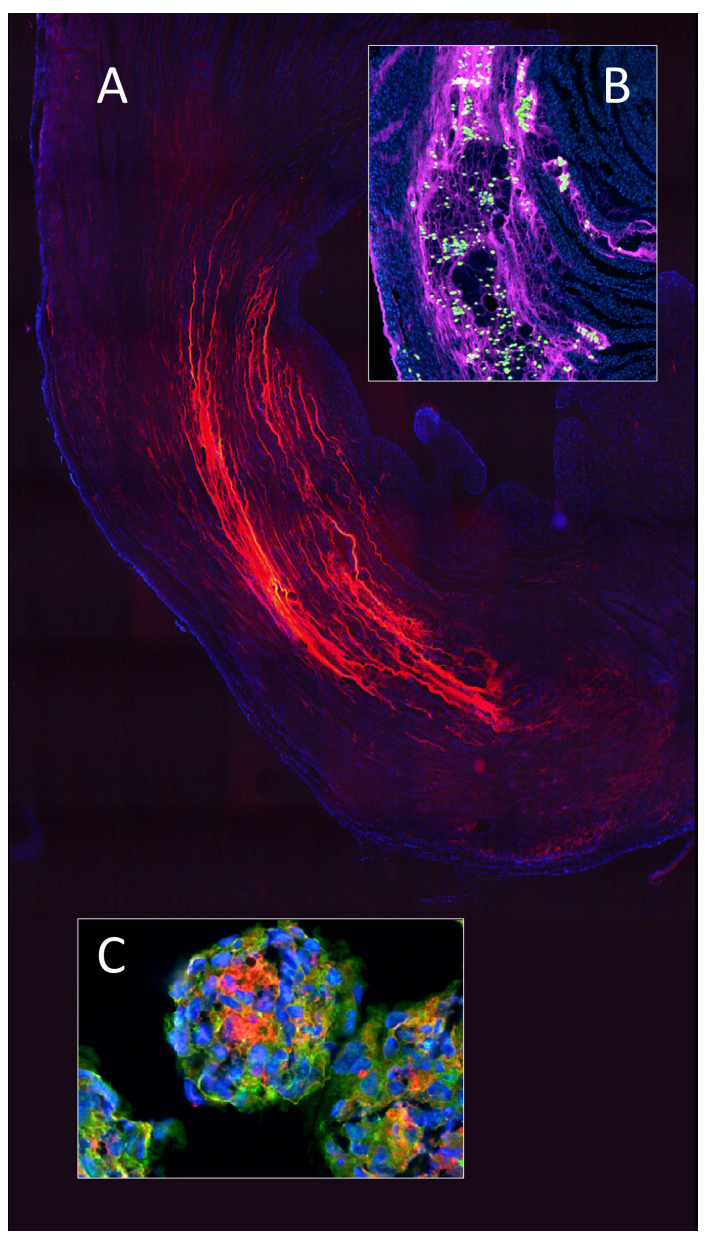

FIGURE 8 | In myocardial regeneration, the potential of a hydrogel (polyethylene glycol) to preserve space and entrap cells is demonstrated with fluorescent labeled PEG (Alexa $665 \mathrm{~nm}$ ) seen polymerised between the cardiomyocyte bundles in an infarcted rat heart (A). The advantageous effect on stress reduction through wall remodeling was much more pronounced if the gel injection was delayed. Inset (B) shows a similarly labeled PEG hydrogel entrapping adipose derived mesenchymal stem cells (green) within the infarcted wall of a rat heart. To improve cellular retention in myocardial regeneration therapy, cellular self-assembly into 3D microtissues (3D-MTs) using the "hanging drop" method $(178,179)$ prior to intra-myocardial injection (C) and compact $100 \mu \mathrm{m}$ thick myocardial muscle bundles grown from human induces pluripotent stem cells (hiPSC) (176) or human embryonic stem cells (hESC) (177) have emerged as an encouraging alternative to single cell injection "therapy" with its high cell loss due to a lack of entrapment. 3D-microtissues have been shown to significantly enhance the angiogenic activity and neovascularization potential of stem cells. From (180) and (179) with permission.

as a murine fresh infarction model may be, the majority of patients in need of myocardial regeneration are not suffering from acute but chronic ischaemia. The "replacement fibrosis" of acute infarction (191) is distinctly different from the extracellular matrix environment building up (192) in chronic ischaemia (193) where a highly cellular interstitial environment, enriched in matricellular proteins and capable of transducing growth factor responses may be required for structural and functional recovery
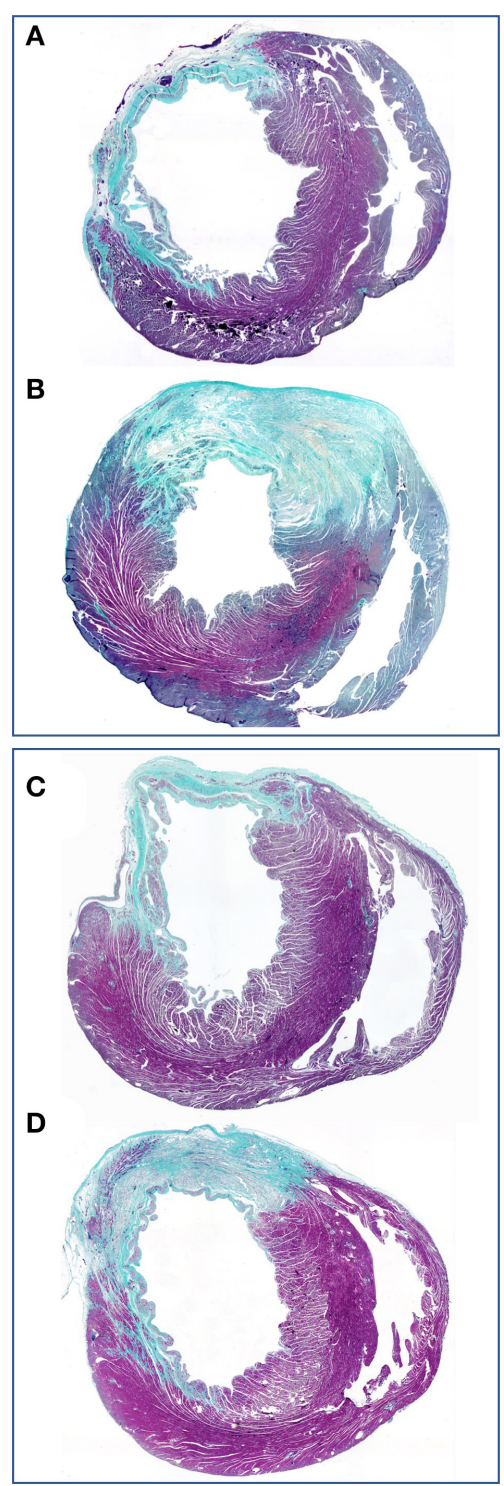

FIGURE 9 | Concomitant stress reduction through gel injection in post infarction myocardial regeneration. The preservation of wall thickness in infarcted rat hearts after injection of polyethylene glycol hydrogels is clearly visible at 4 weeks $\mathbf{( B )}$ and 13 weeks $(\mathbf{D})$ relative to untreated controls $(\mathbf{A}, \mathbf{C})$. Finite element models $(185,186)$ have shown that this mitigation of detrimental post-infarction remodeling dramatically reduces the ventricular mechanical stress (187) that drives the infarcted heart toward failure. Green (scarring) and purple (viable myocardium). From (183) with permission.

(193). Similar to other areas of cardiovascular tissue engineering, focused and carefully considered models like Wolfgang Schaper's chronic ischemic heart model of the 1970 (194) gave way to the more expedient acute ligation models with their exclusive focus on acute ischaemia $(195,196)$.

\section{Two-Stage Co-culture of Scaffolds and Cells}

The idea of sufficiently multiplying autologous cells in vitro before creating confluent functional cell layers on the blood surface of an implant again goes back to the artificial heart 
research of the 1960s. Adapting a method of culturing human endothelial cells that was first described in 1963 (197) it was once more Baylor College that successfully pioneered the invitro culture of autologous cells on the silastic membranes of circulatory assist devices (23) followed by the in-vivo proof of the antithrombogenicity of such a lining (32). At the height of pneumatically driven artificial hearts shear stress resistant confluent endothelial monolayers were created on the displacement membranes of a variety of TAHs (198-201). However, this very first tissue engineering approach utilizing cell culture never materialized as a game changer in clinical practice and quietly faded away as modern assist-devices made it obsolete.

A decade later, the group in Vienna-intimately involved in the initial clinical trials with single stage venous endothelial cell seeding of vascular prostheses $(202,203)$ - introduced mass-culture of autologous endothelial cells (79) to create shear-stress resistant confluent monolayers (204-206) prior to implantation. Preclinical trials confirmed the persistence and non-thrombogenicity of such tissue engineered grafts in a nonhuman primate model (207). An attempt to replicate this concept using cryopreserved multidonor allogenic endothelial cells in order to create "off the shelf" grafts was unsuccessful in the same senescent non-human primate model (208) (Figure 10). A clinical feasibility study was successfully done in 1989 (210) and a randomized clinical trial showed autologous in-vitro endothelialisation to dramatically improve the 3-year patency of femoro-popliteal and femoro-distal bypass grafts (211). Based on this evidence the group adopted this cell culture-based method as a routine procedure for all patients who had no saphenous vein available with excellent clinical outcome (212). Although a significant proportion of patients had distal reconstructionsa patient group with particularly poor prognosis-the 8 (213), 9 (214), and 12 year (215) patency rate of these grafts was continuously superior even to vein grafts. These excellent results were confirmed in more than 300 patients with a follow-up period of up to 17 years (80) (Figure 11). By then, some early limitations of this two-staged method had also been resolved. The initially experienced failure of some patients' own endothelial cells to proliferate into mass cultures had been overcome once risk factors like serum levels of lipoprotein a and triglycerides had been identified (146) and addressed (147). While delays between cell harvest and availability of the tissue-engineered grafts remained the biggest obstacle for acute clinical indications, improved mass culture techniques based on in-situ procedures and very-low density plating that cut out cell passaging had distinctly shortened this lag phase (79). Similarly, clinically used attachment matrices had been optimized $(205,206)$ culminating in an RGD-enriched, engineered lattice providing significantly enhanced shear stress resistance for the endothelium (216). The final proof of success came with the demonstration of a confluent endothelium on mid-segments of clinically explanted in-vitro endothelialised grafts from as early as 30 days (217) to almost 4 years after implantation (218) (Figure 11) and the histological proof of genuine arteriosclerotic changes more than 10 years after implantation (80) (Figure 12).
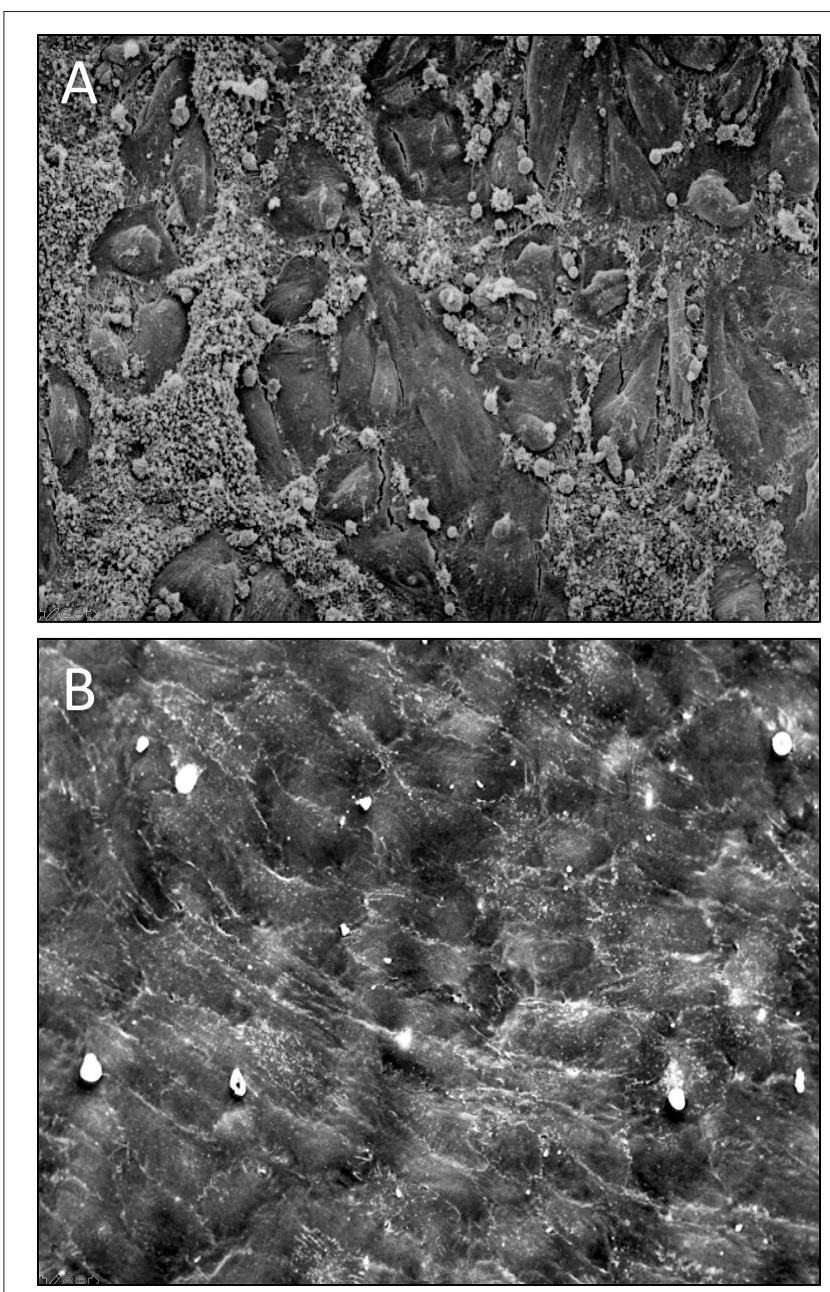

FIGURE 10 | (A) Scanning electron micrograph of the midsegment of a $4 \mathrm{~mm}$ ePTFE graft, in-vitro enothelilised with mass-cultured, allogenic, multidonor endothelial cells after 16 days of implantation as femoral graft in a senescent Chacma Baboon. Only residual cell islands are left of an originally confluent endothelium at the time of implantation interspersed with denuded areas with densely adherent leukocytes and platelets. (B) Confluent monolayer of autologous endothelial cells 4 weeks after implantation of an in vitro endothelialised 4-mm ePTFE femoro-femoral graft into a senescent baboon. One can still recognize the underlying structure of the PTFE graft. No endothelial cell detachment was found in spite of the shear stress exposure. The antithrombogenic potential of the cultured endothelial cells was reflected by a higher patency rate and the lack of platelet or fibrin depositions. With permission from (208) and (209)

At the height of in-vitro endothelialisation of vascular grafts, the concept was also applied to bioprosthetic heart valves. Glutaraldehyde detoxification made it possible to grow endothelial cells to confluence on bioprosthetic leaflets (219223). Such in-vitro lined tissue valves maintained endothelial integrity in the heterotopic primate model $(224,225)$ and even showed some degree of mitigation of tissue calcification (225, 226). However, when the extent of residual immunogenicity of conventional bioprostheses and its role in tissue calcification became apparent (227-229)better immune masking either 

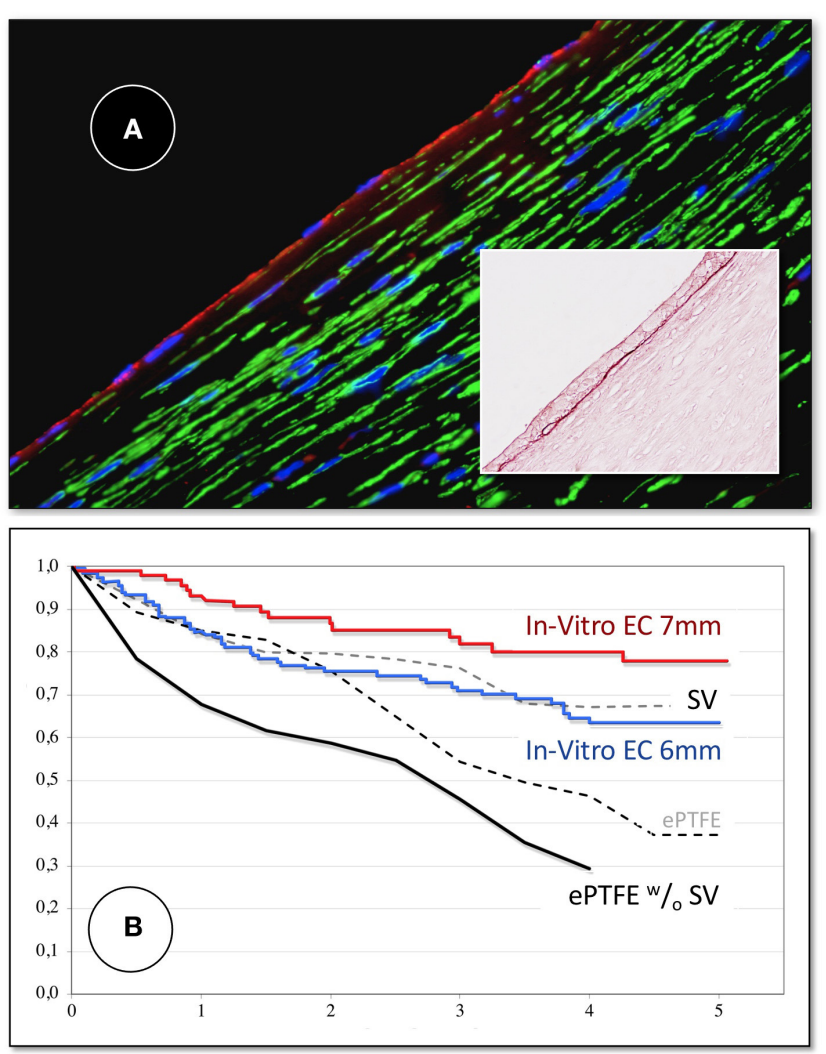

FIGURE 11 | (A) Midgraft segment of an autologous, in-vitro endothelialized graft 41 months after implantation showing a confluent endothelium (CD 31) resting on layers of well-aligned actin-positive cells. A delicate intima was demarcated from the $\alpha$-SMC actin positive cells by a well-defined internal elastic membrane (Insert: Orcein). (B) Primary patency (y-axis) over time (x-axis in years) highlighting the clinical benefit of autologous in-vitro endothelialisation in 6 and $7 \mathrm{~mm}$ femoropopliteal bypass grafts of 341 consecutive patients opposite a comparable patient group randomized to receive saphenous vein ("SV") and ePTFE grafts ("ePTFE") [with permission (37)]. The entire cohort of patients receiving an in-vitro endothelialised grafts had no saphenous vein available and as such, an ePTFE graft was an obligatory choice for each of them. Therefore, the patency of endothelialised grafts needs to be compared with that of the subgroup in the randomized Veith et al. study where an ePTFE prostheses was equally obligatory ("ePTFE w/o SV"). From (80) with permission.

through decellularization (230-233) and/or higher crosslink efficiency $(234,235)$ became the primary goal rather than a living endothelium. Also still in the 1980s Libby and Birinyi (236) and Pober et al. (237) had shown that under such circumstances an endothelium would augment rather than suppress an inflammatory process $(236,237)$ as the exposure of ECs to inflammatory cytokines, such as IL- 1 or TNF- $\alpha$, would cause the ECs to bind manifold more leukocytes (238) due to the induction of endothelial leukocyte adhesion molecules (ELAMs) (239). As such, an endothelium on conventional bioprosthetic leaflets even after detoxification would continually be proinflammatory (236). Attempts to reduce immunogenicity by decellularizing allografts (240-246) and xenografts (242, 247-251) before lining them with cultured endothelial cells were followed by clinical trials with in-vitro endothelialised, decellularized allografts (250, 252-254).
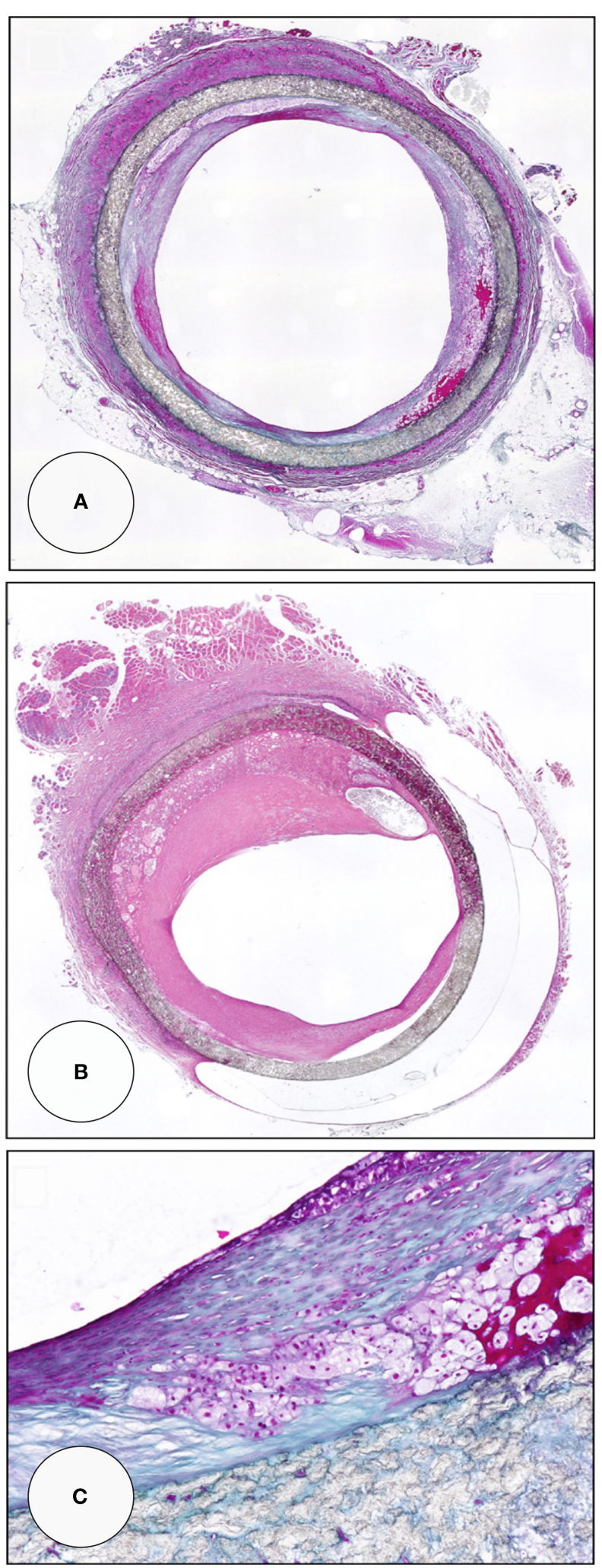

FIGURE 12 | Midgraft segments of two in-vitro endothelialised

femoro-popliteal grafts explanted at the time of re-operation for graft failure 41 months $(\mathbf{A}, \mathbf{C})$ and 63 months $\mathbf{( B )}$ after implantation. Both specimens contained

(Continued) 
FIGURE 12 | other areas of more significant stenoses but the displayed pre-stenotic regions were packed with large islands of foam cells. Typically, the foam cells were wedged underneath pannus-like, cell-poor tissue that occasionally showed stretches of complete acellularity (B). From (80) with permission.

When the in-vivo performance of equally decellularized matrices compared in-vitro endothelialisation with decellularization only, there was no difference (255) leading over to the later approach of non-vital decellularized native valve implants (256).

While the first two decades of tissue engineering were firmly tied to permanent scaffolds, this began to change in the 1980s. Long before anyone else, cardiovascular surgeons in Groningen had the idea of making the scaffolds gradually disappear while allowing functional tissue to develop (257-261). Pioneering this concept as early as in 1983 (261) they preempted key elements of the subsequent era like biodegradable polymer grafts inoculated with cultured smooth muscle cells (262). Yet, the catchy term "tissue engineering" — not coined but popularized-several years later by Joseph Vacanti, a surgeonscientist at Boston's Children's Hospital and Robert Langer, a chemical engineer at the MIT (263) contributed to the lasting association of Boston with this approach. When they began their efforts, their underlying concept had a holistic rather than a cardiovascular claim. Indicative of the broader scope of their approach, the initial clinical problem they strove to resolve was curing diabetes through pancreatic islet transplantation (264) followed by attempts to re-grow cartilage (265). Toward, the mid 1990s, the "Boston group" had expanded this concept to heart valves (104) and shortly later also included vascular grafts (266) co-culturing embedded autologous arterial and venous cells within degradable scaffolds made of polyglactin/PGA fabric. Replacing a single valve leaflet in a sheep (104) confirmed the concept but also the previously shown superiority of autologous tissue engineered implants over their allogenic counterparts (208). However, at explantation leaflets were thicker and stiffer than native leaflets and did not have the delicate, differentiated microanatomy required for stressreduction during opening and closing (104, 267, 268). The phenomenon of fibrosis and tissue shrinkage associated with a macrophage driven resorption process was seen in all animal models including senescent primates (269). This healing mode was well-known from the tissue reaction to resorbable surgical sutures made of the same polyglycolic- (PGA) and polylacticacids (PLA) or polycaprolactone (PCL) materials which had been clinically used for decades (270). Attempts to minimize this cicatrition in favor of more mature valvular tissue included addressing biomechanics (271-273) as well as inadequate cell growth in the depth of the scaffolds through pulsatile bioreactors (274). Polymers were also iterated using natural polyesters like Polyhydroxyalkanoate (PHA) $(271,272)$ and Poly4-Hydroxybutyrate (P4HB) (275). At the same time, the issue of the cell source also remained a challenge for two-stage culturebased approaches. Attempts to optimize the ease of harvest and the yield followed again in the footsteps of the previous era by either trying allogenic cells (276) or different autologous cell sources like bone marrow cells (275), mesenchymal stem cells (277), umbilical cord blood derived EC progenitor cells (278), prenatally harvested progenitor cells (279), human induced pluripotent stem cells (hiPSCs) (280) endothelial progenitor cells (EPC) (92) including reprogrammed and reconditioned cells (281). Different from previous eras, however, significantly more resources and internationally attracted manpower had characterized the "Boston era." Eventually, fellows of John Mayer's group carried the program to other institutions in the early 2000s: Simon Hoerstrup to Zurich (282) [later on also collaborating with Frank Baaijens' group in Eindhoven (283)], Toshiharu Shin'oka to Tokyo $(156,157)$ and Christopher Breuer to Yale (later Ohio State) $(160,284)$. While other researchers like Laura Niklason at Duke (later Yale) $(285,286)$ also started their programs initially on the basis of bioreactor-based vital implants using degradable scaffolds (163), the group in Montreal went a step further. In an attempt to avoid all synthetic scaffolds and the associated problems of shrinkage and fibrosis, L'Heureux and Auger created polymer-free neo-vessels consisting of adventitial fibroblatsts, medial smooth muscle cells and an endothelium (287-291) Their extreme modern pendent are 3D printed pure stem-cell grafts (292). In clinical pilot trials with L'Heureux's $\mathrm{AV}$-shunts graft dilatation was observed (288). In line with the general desire to cut out an autologous culture step and offer a product off the shelf their next generation of tissue-cultured vascular grafts was still autologous but devitalized to be storable (293) followed by a further step toward a commercial product by using devitalised allogenic cells (294). This step away from vital implants stood at the beginning of a general return to the concept of in vivo tissue regeneration of non-vital scaffolds originally pursued from 1968 onwards for artificial hearts (10, 11, 24, 3436).

In retrospect, of all the vital tissue engineering concepts pursued, in-vitro endothelialisation was the first and for decades the last embodiment that was successfully translated into clinical practice (Figures 10-12). The successful pilot program ceased when new regulations prohibitively tightened the circumstances under which a patient's tissue may be processed as part of an implantable device outside the operating room. Although this hurdle would be surmountable by establishing integrated facilities and ISO-compatible cleanroom productions the combination of the inconvenience of not having an "off the shelf" product readily available with a protracted process that excludes acute interventions makes a revival of "vital" two-stage tissue engineering unlikely-regardless of whether the scaffold is permanent or temporary.

\section{Non-vital Implants}

The principle behind this approach is the trust that acellular implants stimulate and direct the healing response of the body to not only become in-situ populated with cells but that these cells organize themselves in a way that the resulting tissue fulfills the key functions of the original structure (295). As appealing as this concept of "in-situ" "regeneration" or "guided tissue regeneration" is with regards to "off the shelf" products, it relies on one assumed ability: to recruit cells which can differentiate into the desired functional tissue. As practically all cardiovascular 
tissue engineering attempts of the past decade have coalesced toward non-vital implants, it is paramount to get clarity on their repopulation potential soon. For that, tissue sampling from the crucially important parts of the implants like the distal ventricular side of leaflets or mid-sections of long bypass grafts will be as mandatory as an independent identification and localization of ingrowing cells in order to validate this promising approach.

\section{Native and in-vitro Grown Natural Matrices}

Ironically, two diametrically opposed tissue engineering concepts of the past decades-decellularized allo and xenograft valves and pericardia on the one hand $(242,296,297)$ and vital implants of cultured cells on degradable scaffolds on the other (104)-ended in congruence when the latter added a decellularization step. Now, both concepts bet on the in-situ re-population of allogenic or even xenogenic antigen-reduced, cell-derived matrices. A main challenge of this approach is the fine line between remnant immunogenicity (298-300) and avoidance of crosslinking to allow repopulation with host cells. The fact that a cell-free matrix can still be immunogenic has been shown (301) not least in the catastrophic failure of Synergrafts in children (302). Furthermore, interstitial cells seem to be needed to maintain the microarchitecture of the extracellular matrix (303). While the microarchitecture of the extracellular matrix of allografts is well-preserved in transplant recipients in whom the donor cells survived, the typical acellularity found in allografts from non-immune suppressed recipients is associated with a loss of microarchitecture and hyalinisation of the matrix (303).

Although the verdict is still outstanding whether such constructs will eventually get sufficiently repopulated in humans, one may in the meantime draw parallels from the experience with auto- and allograft heart valves. There, three basic facts emerged: (a) cells can remain vital in the depth of a transplanted native valve provided they are autologous and were already there at the time of implantation (304-306); (b) the survival of allogenic cells in the depth of transplanted native valves is only possible in the immune-suppressed context of heart transplantation but otherwise allograft heart valves become rapidly acellular (307); and (c) in spite of presumably representing the optimal extracellular matrix structure of a native valve, allografts remain acellular after years of implantation $(303,307)$. These observations indicate that in humans, even the destination matrix of a native decellularized aortic valve may remain acellular unless it already contains autologous cells at the time of implantation as is the case in autografts. Theoretically, this absence of cell ingrowth into conventional allografts could either be secondary due to post implantation matrix disturbances resulting from the death of co-transplanted cells or primarily reflect the mitigated trans-anastomotic tissue outgrowth in humans. However, even in larger animal models, the distal leaflet sections remained mostly acellular (308). Therefore, the question as to the source of cellular re-population cannot be evaded. Since all decellularized matrices present at least a temporary barrier for transmural endothelialisation, and significant fall-out healing from the circulation has remained an unfulfilled pipedream for decades $(107,108,113,116,309)$, the partially successful "in-situ tissue regeneration" observed in animals may have its most likely explanation in the vigorous trans-anastomotic outgrowth potential of adjacent intimal tissue in sheep that does not exist in man. Hence, no convincing evidence going beyond facile case reports (308) has been presented yet that unambiguously demonstrated a successful autologous in situ re-population of decellularized native heart valves in patients. Early reports rather highlighted the unresolved issue of remnant immunogenicity of the decellularized matrix in the absence of crosslinking. CryoLife had reported partial recellularization of the distal conduit but an absence of cellularity in the leaflet after up to 11 years in vivo (310). This was followed by the clinical debacle with their decellularized xenografts in children (302). "Leaflet repopulation" was also reported during clinical use of the Matrix PTM line of valves, another decellularized xenograft, but the repopulating cells generally appeared to be inflammatory rather than phenotypically appropriate valve cells (302). Whether non-cardiac-derived decellularized matrices like the "CorMatrix" made from porcine small intestinal mucosa would allow to revisit the non-crosslinked xenograft concept has been decisively answered in a recent study where more than half of the valves failed (311). Together with reoperation rates in humans when used as patches (312) clinicians have been calling for a moratorium on such non-crosslinked decellularized xenografts $(313,314)$. Notwithstanding the conclusion that non-crosslinked decellularized xenografts are showing dangerous inflammation and failure, the excellent clinical performance of decellularized allografts over their conventional counterparts (315-317) makes it likely that the concept will prevail even if it loses the attribute of "guided tissue regeneration" upon more vigorous pathohistological analyses under strictly defined criteria.

While clinical studies with decellularized natural heart valves (318-320), pericardium (296) and vascular grafts (321) have been reported for more than two decades decellularized invitro grown matrices have been tested for equally long-both as heart valves and as vascular grafts-but so far clinical trials have only been performed with vascular grafts. The concept was pioneered by Niklason's group in 2003 (322) decellularizing allogenic PGA/smooth muscle cell (SMC) constructs that were cultured in a bioreactor for 2 months. With the initial focus on dilatation resistance and patency (323) and animal implants mostly reflecting trans-anastomotic outgrowth (324) the key question as to the repopulation of the decellularized matrix in man had to wait for clinical studies. Starting in 2012 (325) sixty "Humacyte ${ }^{\circledR ”}$ access grafts $(325,326)$ were implanted as part of a phase 2 trial and 16 tissue samples ranging from 16 to 200 weeks were histologically analyzed showing sometimes a dense repopulation of the media with $\alpha$-actin positive cells (326). While showing that the decellularized matrix can be populated with mesenchymal cells, the countless wall punctures of access grafts make it difficult to ascertain whether the healing mode was transmural per se or required the puncture holes. A subsequent clinical femoro-popliteal bypass study eventually provided sufficiently long $(28 \mathrm{~cm})$ unpunctured grafts (327) to potentially clarify this issue. Of three obtained specimens, one was at the anastomosis and as such disqualified; one was at a perforation site leaving one specimen where the 

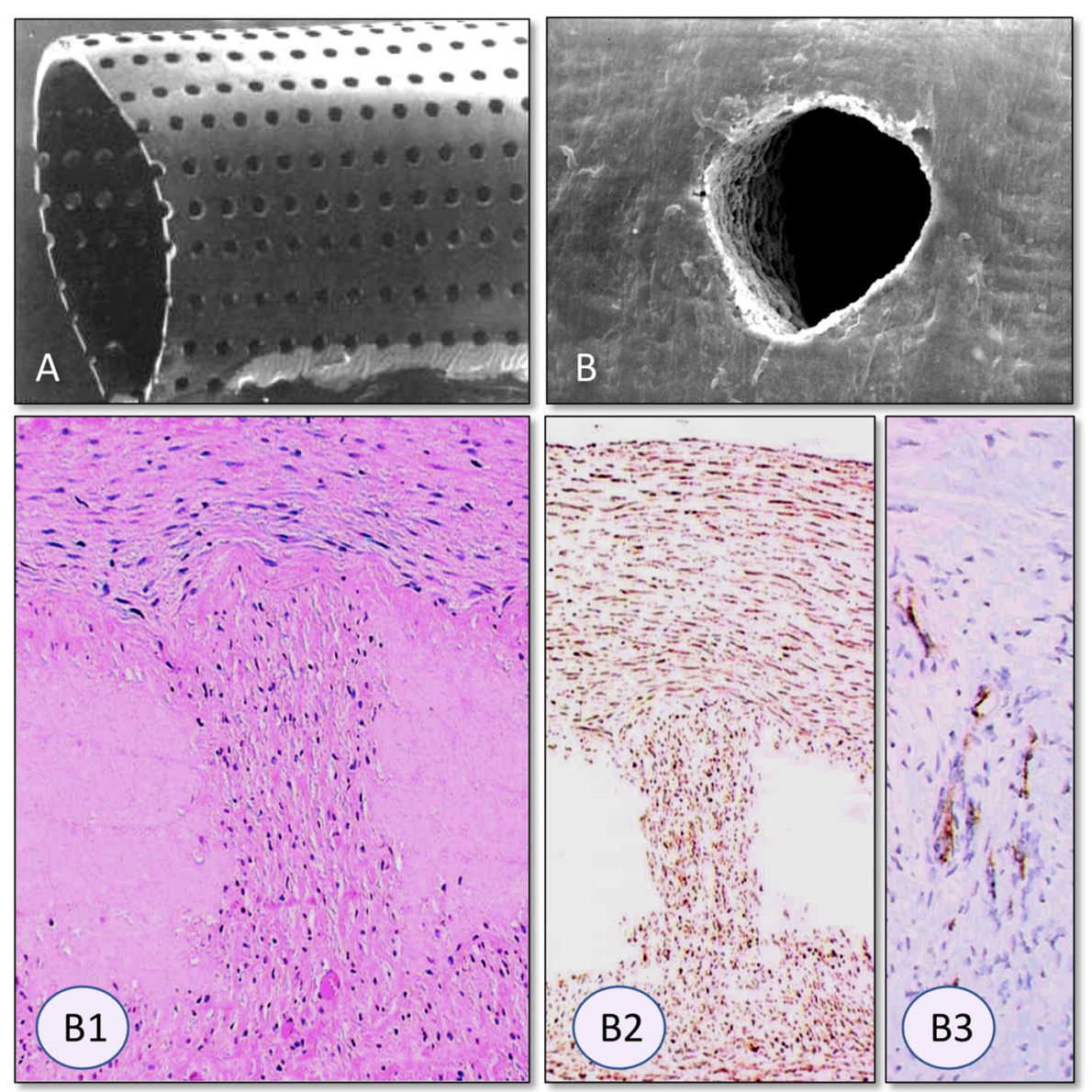

FIGURE 13 | Radial Laser holes creating ingrowth permissible spaces in vascular grafts. (A) Laser holes in polyurethane grafts and (B) a decellularized arterial allograft. The clear-cut edges without tissue trauma are typical for very short-waved lasers (330). Trans-mural tissue ingrowth from the adventitia after 3 months of carotid interposition grafting in sheep. In spite of dense fully transmural tissue ingrowth through the laser perforation the decellularized allograft tissue surrounding the laser hole remained acellular (B1). Vimentin positive fibroblasts were restricted to the laser channel (B2). Within the laser hole, neovascularization was restricted to the outer half as capillary sprouting did not reach the graft lumen (von Willebrand staining) (B3). From (331, 332) and (329) with permission.

low-density cell infiltrates could have been evidence for a transmural repopulation. Likewise, the luminal irregularities after 24 months, reflected in angiographic diameter variations between 2.9 and $5.8 \mathrm{~mm}$ could alternatively be interpreted as signs of tissue formation or thrombotic appositions. Similarly, the described lack of an endothelium may have been due to the preceding attempts of balloon thrombectomies (327) or to the a'priori absence of an endothelium due to a lack of significant trans-anastomotic outgrowth in man and the absence of transmural endothelialisation. As such, what still remains to be proven is whether a healing mode proposed by Grabenwöger's group in Vienna as early as in 1998 $(328,329)$ whereby radial micro-holes greatly augmented the repopulation of decellularized matrices will eventually be required to also see surface endothelialisation on such in-vitro grown, decellularized matrices. It would, however, not simply be a punching-out of holes but a fine-titration between too broad ingrowth spaces that may lead to premature connective tissue maturation preventing further capillary sprouting (Figure 13)
(329) and insufficient ingrowth spaces. As an alternative concept to decellularization, L'Heureux's group clinically pursued devitalisation through airdrying. Initially, the devitalised grafts were still partially re-vitalised by in vitro lining with the patient's own endothelial cells (293). This hybrid approach was followed by completely devitalised non-endothelialised allogenic grafts (“Lifeline Grafts ${ }^{\circledR}$ ”) (294) eventually leading to woven textile structures using yarns of devitalised in vitro grown tissues (333). No repopulation, however, was ever reported in any of these grafts. Leaning on L'Heureux's earlier work (290), Syedain's group in Minneapolis using fibrin gels to create scaffold-free cell-produced decellularized vascular grafts (334) provided the most convincing repopulation evidence yet. They implanted $15 \mathrm{~cm}$ long $\mathrm{AV}$ shunts in middle-aged non-human primates (Papio Anubis) that remained unpunctured throughout. Within large animal models, Papio Anubis seems to come closest to the senescent Papio Ursinus model that was previously shown to reflect the trans-anastomotic outgrowth-stoppage (102) seen in humans (107). The study convincingly demonstrated the 
repopulation of the mid-graft media with mesenchymal cells that likely originated from the adventitial side (334). Yet, as it did not show traces of transmural angiogenesis and a largely absent endothelium in the mid-graft region it also highlighted once more the dependence of endothelialisation on trans-anastomotic outgrowth on these matrices-something one cannot expect in humans to occur.

Corresponding with a proven wall-repopulation but an unresolved endothelialisation mode were the suboptimal clinical results with these decellularized, bioreactor-grown vascular grafts. "Lifeline" grafts were disappointing though they were few. "Humacyte," in contrast, had 60 access grafts implanted at 6 centers $(325,326)$ and 20 femoro-popliteal grafts at 3 centers (327). Primary patencies were low both in the access grafts and in the femoro-popliteal grafts. In access grafts where the 1year primary patency is known to be between 43 and $57 \%$ for ePTFE grafts $(58,59)$, it was $28 \%$ for the "Humacyte" grafts (325). In above-knee femoropopliteal bypass grafts with good run-off the 2 year primary patency was $58 \%$ (327) compared to $73 \%$ in ePTFE grafts for a similar patient group in Frank Veith's multicentre study (37) and 80\% for in vitro endothelialised $6 \mathrm{~mm}$ ID grafts in comparable patients (80). In vitro endothelialised $7 \mathrm{~mm}$ grafts even had a 2 year primary patency of $88 \%$ in spite of also including patients with distal reconstructions with poorer run-off (80).

During the past decade the concept of decellularized cellproduced matrices was also carried over into heart valves. The group in Zurich decellularized their well-established tissue engineered constructs of cultured human fibroblasts on a degradable scaffold (335). Using the senescent baboon model (335) and the sheep model-first for transcatheter pulmonary valve replacements (336-338) and later for orthotopic TAVIs (339) - in depth repopulation of such a matrix with mesenchymal cells was demonstrated. The patchy endothelial cover of the leaflets $(158,339)$, however, again hinted at the likely dependence of surface repopulation on the transanastomotic outgrowth seen in sheep. Furthermore, leaflet shrinkage as a consequence of repopulation emerged as an inevitable consequence of early tissue maturation $(335,336$, 338) but could be addressed by shape compensation during production (340). Syedain's group in Minneapolis also tested their scaffold-free, fibrin gel-based cell-derived decellularized matrix in surgically implanted aortic valve replacements in sheep (341). Similar to others (158), repopulation with $\alpha$-SMA and Vimentin positive cells was primarily seen at the leaflet base while distal leaflets remained poorly cellularized and only sporadically endothelialised.

As such, decellularized in-vitro grown matrices have successfully shown their ability to get repopulated by mesenchymal host cells primarily in areas of tissue contact with the host. The sub-optimal clinical performance of vascular grafts as well as the decreasing endothelial coverage with increasing distance from the nearest anastomosis, however, suggest again a dependence of the neointima formation on the trans-anastomotic outgrowth occurring in animals.

\section{Synthetic (Functionalised) Scaffolds}

The idea that synthetic implants contain morphogenic cues to stimulate the in situ regeneration of key cardiovascular structures again goes back to the early days of tissue engineering. There, the goal was to induce the in-vivo formation of a non-thrombogenic "neointima" on artificial hearts $(10,11,24,32,34-36)$ and vascular grafts (342) merely on the basis of iterations of porosity and surface structures. Clinical success never materialized for the same reasons it hasn't materialized half a century later when biomechanics and molecular biology provided the tools to recapitulate refined biophysical and biochemical properties of the target tissues. (343-345). The reason for the continual absence of a clinical translation of this concept lies in decades of experimental cross-purpose design between a biologically possible tissue regeneration response and one that is actually feasible at the intended site and in the intended host environment. Although we have already highlighted that this has been the overarching dilemma of all tissue engineering approaches of the past decades, it is particularly pertinent for non-vital synthetic implants as their clinical performance depends much more on the in-situ formation of functional tissue (346) than any other concept. As such, an eventual break through of "in vivo" generation of functional tissue in synthetic scaffolds will not depend on whether the cues provided replicated nature best but whether they were based on appropriate assumptions regarding the host response.

After it had been shown that the cellular source of "fall out" healing was predominantly from endothelial precursor cells in the bone marrow $(347,348)$ and that these endothelial progenitor cells (EPCs) express amongst other ligands the vascular endothelial growth factor receptor VEGFR-2, as well as the CD133 and CD34 antigens (349-351) several attempts were made to augment the homing of these cells onto "nonvital" synthetic grafts by immobilizing anti-ligand antibodies on the surface $(352,353)$ including antibodies against chemotaxis stimulating receptors on stem cells (354). Yet, even with sporadic studies showing an enhanced recruitment of circulating cells $(349,355)$, without a broad consensus to focus on endothelialisation and cell population from the circulation, this approach will continue to remain an unrealised promise. As such, transmural ingrowth and endothelialisation remain the most realistic modes of tissue regeneration for synthetic scaffolds.

For permanent scaffolds to achieve successful transmural healing, ingrowth permissive spaces were shown to be a sine qua non. The minimal dimensions of such spaces were well defined at $80-400 \mu \mathrm{m}^{2}(102,356)$ optimally even being as large as 5,000$6,000 \mu \mathrm{m}^{2}$ (357). Therefore, if transmural endothelialisation and healing is the goal, this requirement would exclude the use of ePTFE of $<60 \mu \mathrm{m}$ internodal distance, woven Dacron and most of the electrospun polyurethane grafts unless their scaffold structures were manipulated to increase the interfibrillar spaces (357-360). Yet, making transmural endothelialisation of synthetic scaffolds a reliable occurrence also requires the suppression of the surface compaction with interstitial thrombus (107) (Figure 14). Therefore, functionalising the scaffolds with pro-angiogenic signals (361-368) must not only be seen as 
quantitative augmentation of angiogenesis but as the attempt to outpace the build-up of an inhibitory barrier. Encouragingly, however, thin walled ePTFE of 60-90 $\mu \mathrm{m}$ IND $(102,123,135)$ whose porosity was known to provide the necessary vascular ingrowth spaces (102) was shown in non-human primates to successfully achieve transmural endothelialisation without the need for any ingrowth augmentation (102, 123, 125, 369). Regrettably, the clinical confirmation of this observation was thwarted by regulatory concerns leading to a last minute addition of a very low-porosity wrap on the outside (370) of PTFE grafts turning high-porosity into low-porosity prostheses. One of the many puzzles in tissue engineering is why the "real" clinical study never happened since, as it would have certainly provided the entire field with much needed "translational" energy.

If the complexity of a clinical in-vivo environment makes it already difficult to accomplish transmural endothelialisation (371) in non-degradable scaffolds one needs to reckon with additional challenges in degradable scaffolds. There, it is less an issue of whether sufficient ingrowth spaces are pre-existent or progressively "open up" during degradation but whether the inflammatory process accompanying the break-down of the scaffold introduces additional obstacles. While "harnessing the natural inflammatory process" has been the underlying principle behind the degradation and replacement of a temporary scaffold with newly formed tissue (371-375) its effect on transmural endothelialisation has not been tested yet. Some data on electrospun heart valves confirm the presence of intramural vessels and mesenchymal cells corresponding with tissue contact (Figure 15) but a clear distinction from a trans-anastomotic origin cannot be made (158). If the latter was the case, even the intramural cell population of the scaffold would likely be different in humans. The proximity of a trans-anastomotic endothelium to a pro-inflammatory environment would trigger the active recruitment of inflammatory cells from the circulation (236, 237). The known trans-differentiation potential of such actively recruited mononuclear blood cells (85-91) and their ability to participate in the intramural cellularisation process and neotissue formation of a synthetic scaffold (87) makes it likely that the entire healing pattern would thus be distinctly different in humans. Ironically, a successful and rapid replacement of a biodegradable scaffold by mature mesenchymal tissue may even prematurely terminate endothelial migration (376) thereby thwarting transmural surface endothelialisation all together. While the iteration of scaffold chemistry $(371,377)$ and microstructure $(371,378)$ would allow the titration of the degradation process $(371,379)$ the actual clinical requirements against which to titrate remain again poorly defined in the absence of better suited animal models. Whether inserted as infra-renal interposition grafts in rats $(260,377,380)$ or comparably short interposition grafts in rabbits $(381,382)$, dogs (383, 384), mice (385), sheep $(386,387)$ or pigs (388-390): trans-anastomotic outgrowth has again most likely overpowered any other form of healing in these studies on degradable scaffolds. Even if tubular structures contained valves, transanastomotic neointimal outgrowth provided the most probable cell source for the leaflet population observed (158, 379). In the expected absence of a neo-intima reaching the distal leaflets in humans, this may lead to situations where leaflet degradation precedes tissue formation. Clinical pilots added to this concern. Based on the equilibrium between degradation of modern supramolecular polymers originally developed in Eindhoven $(379,391)$ and tissue formation observed in the sheep (386) an early clinical feasibility/first in man study was commenced with pulmonary valves implanted into children. The developing post-implantation coaptation deficiency of leaflets in 11 out of 12 valves (392) hinted at a healing behavior not seen in the sheep. Without histological proof to the contrary, a lack of tissue formation in the distal leaflets will always seem the most likely explanation given the known healing deficiencies in humans. The subsequent corrective modifications of the polymer degradability (392) may have retrospectively led to well-functioning polymeric heart valves but may still defy the claim of eliciting "endogenous tissue restoration." In a parallel clinical trial using the same material for extracardiac TCPCs (393) the close contact of the tubes with their surrounding tissue may eventually lead to successful transmural healing. However, the likelihood of obtaining sufficient representative samples within a meaningful time frame is very low in both trials: RVOT revisions increasingly happen endovascularly and TCPCs only yield samples in the rare occasion of a transplantation or death many years later. Long term animal implants published since have confirmed in similar supramolecular polymer valves that even in an animal model with excessive trans-anastomotic outgrowth like the sheep cellularisation was mainly restricted to the leaflet base while the distal leaflets remained poorly cellularised with only patchy endothelium (158).

As such, any tissue engineering approach that justifies the word "engineering" will require animal models which allow a rational and mechanistic exploration of key components of the "endogenous tissue restoration" expected at the clinical destination site. A myriad of fascinating modern scaffold materials for instance has been investigated under in-vivo conditions which did not emulate key cornerstones of the human situation ranging from thermoplastic polymers such as degradable polyurethanes (394); poly-e-caprolactone (PCL)alone or in combination with poliglecaprone (395), with polydioxanone (396) or with Gelatine (397)- "supramolecular": ureic-pyrimidone-modified polycaprolactone $(158,398)$ also in combination with ureic pyrimidone PEG (398) to thermoset polymers such as polyglycerol-sebacate (PGS) (399) or nanofiber scaffolds of naturally occurring polymers such as polysaccharides (cellulose) (400-402); hyaluronic acid (343); silk (385, 403), collagen (404), Elastin-like blends (405, 406), fibrin (407), or collagen-elastin (408). For none of these materials do we have an answer to two of the critical questions asked at the beginning: (1) as scaffolds, do they allow transmural endothelialisation or alternatively facilitate true fall-out endothelialisation and (2) given the absence of trans-anastomotic neointimal outgrowth in man: is scaffold degradation (eg., by blood borne inflammatory cells) balanced against neo-tissue formation to prevent a premature structure-loss in patients? The same questions need to be asked with regards to the effect of incorporated/grafted bioactive molecules such as VEGF $(361,366,367,409)$, NO 


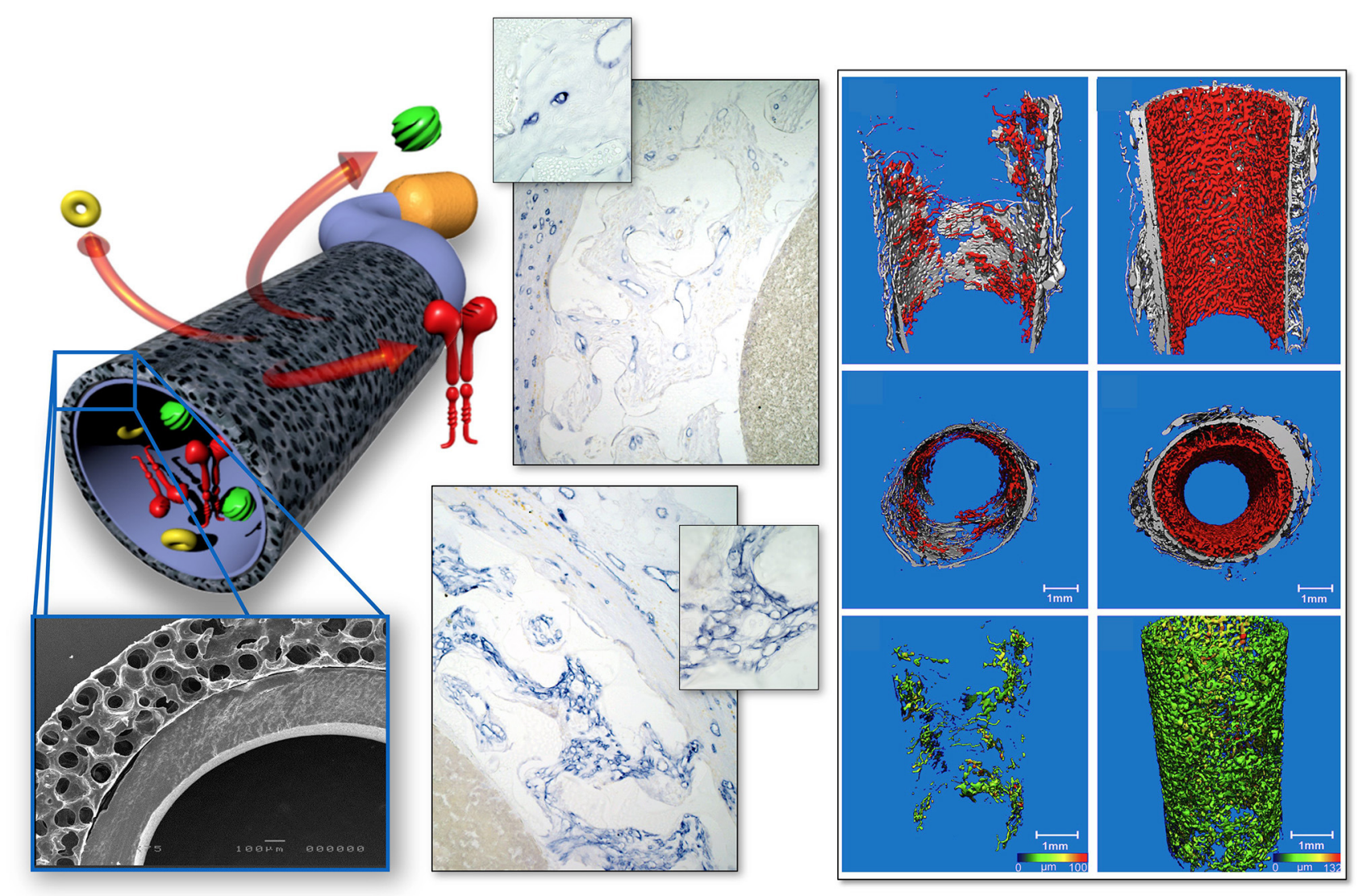

FIGURE 14 | Transmural endothelialisation model in the absence of interference by trans-anastomotic endothelialisation or surface thrombus compaction. Rat subcutaneous implantation of low-porosity ePTFE-lined ingrowth permissible constructs connected to an implantable osmotic mini pump allowing well-defined administration of pro-angiogenic cues. Transmural neovascularisation is image-analytically assessed on histology and by high resolution micro-CT. From (361) with permission.

(364), TGF-b (410), SFD-1 (411), and many others (368, 412) not to mention the various ingrowth gels whether they are from natural proteins $(388,407,413,414)$ or fully synthetic (415); functionalised, (416-422) and/or potentially cell selective (423). For gels, however, an important second purpose may emerge as "space-holders" further facilitating transmural endothelialisation. In this role, their presence in the interstices of the scaffolds may also prevent the build-up of impenetrable thrombus near the blood surface until the gels get replaced by ingrowing tissue.

\section{CONCLUSION}

Over more than five decades, cardiovascular tissue engineering has gone through many distinctive eras from synthetic nonvital polymer implants to vital implants and back to synthetic, non-vital implants. It certainly contributed to the perception of recurring re-inventions that the distinct eras often re-established capabilities rather than integrated previously gained expertise. While scientific depth and sophistication increased over time, insight into both clinical needs and the fate of protheses in patients got lost. Amongst other developments, this growing detachment from clinical needs arose out of the transition from surgeons being the driving force to scientists. Reflecting the unprecedented progress of science in the last half-century, this transition was a natural consequence of the evolving sophistication of cardiovascular biology and material sciences. As a result, it provided an array of building blocks with a hitherto unprecedented potential of creating truly functional replacement parts for the heart and for blood vessels. Yet, empowered by this impressive armament-why are patients still not benefiting from "tissue engineered implants" unchanged from almost 60 years ago? Perhaps the sine qua non of product developmentthe user needs without which no modern device would ever pass the regulatory hurdle-had faded away. These "user needs" were originally backed by clinicians and pathologists being intimately involved with the developments. At the root of this waning association between clinical purpose, human pathobiology, and laboratory based solutions stands the diminishing feedback regarding the fate of implants in patients. During the pioneering days of cardiovascular surgery and typical for the overall spirit and often crude ethical standards of the 1960s, there 


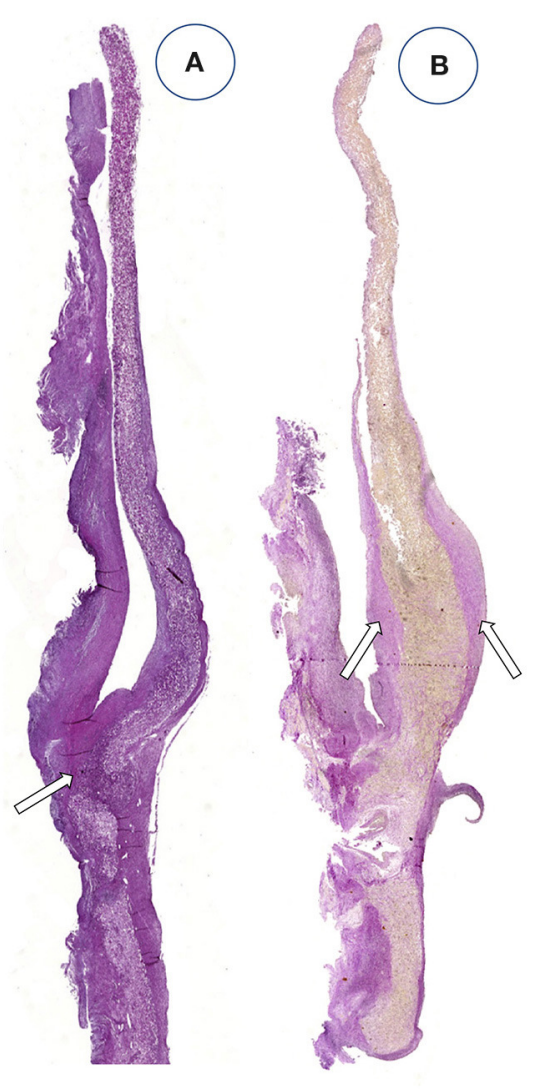

FIGURE 15 | Leaflets of two different electrospun heart valves made of the biodegradable supra-molecular polymer bisurea-modified poly-carbonate (PC-BU) after 24 weeks of trans-catheter pulmonary valve replacement in the sheep. The leaflet cellularity generally decreased with distance to the leaflet base with minimal tissue deposition observed toward the free edges. Leaflet remodeling depended on stent integration in the surrounding tissue with transmural population of the leaflet base with polymer absorption and ECM deposition in the well-integrated valve (A) and poor cell population, surface overgrowth of tissue and a lack of collagen deposition in valve (B), which was in line with its poor stent integration and migration over time indicating the dependence of the cell population of the leaflet scaffold on transmural ingrowth. From (158) with permission.

was a low threshold for the clinical use of new prostheses on top of shorter life expectancies of patients. Together, they provided ample pathological evidence most prominently on the issues of trans-anastomotic outgrowth inhibition and transmural ingrowth inhibition. At that time, histological and macromorphological explant analyses of extensive clinical series often outweighed animal data. As failed grafts were surgically re-operated, clinicians had a first line opportunity to confirm the pathology. As such, no surgeon of this generation would have expected any tissue regeneration approach to rely on transanastomotic endothelialisation as no one would have expected a neointima that takes 10 years to cover $<10 \mathrm{~mm}$ of a prosthesis to ever be able to endothelialise the remaining $50 \mathrm{~cm}$ of a distal bypass graft. Similarly, every pathologist of this era would have been able to describe the build-up of a hostile ingrowth barrier at the blood surface even in the presence of a most favorable graft porosity for trans-mural endothelialisation.

With the dawn of endovascular interventions, though, the first to lose the background knowledge of vascular pathology were the surgeons themselves. Particularly in large animal trials it were surgeons who uncritically implanted far too short interpositions to test prostheses that had clinical translation as an end goal. While the fading awareness of human pathology increasingly misled expectations regarding the tissue response at the host site something similar happened regarding the clinical needs. The detachment of scientists from a fast changing clinical practice often led to out-of-date motivations for their tissue engineering efforts. It is puzzling how exciting approaches using the most recently developed materials, cell programming or matrix engineering continue to state needs behind their research which have long outlived clinical practice.

What needs to be done? For one, adding more tools to an already overflowing, rich tool-box of modern material science, matrix- or cell biology will be unlikely to lead to a breakthrough in clinical translation. In order to achieve a break through, the key obstacle of aborted healing-be it trans-anastomotic outgrowth inhibition, the build-up of impenetrable interstitial surface thrombus, insufficient ingrowth spaces or the physical distance to cell sources-will need to be dealt with in a concerted effort. If today's clinical implants make it more difficult to identify the principles of prosthetic healing in the human cardiovascular system, sufficient historical studies are available to extract them. The principles won't have changed! Understanding the healing modes possible in patients will be a prerequisite for trying to facilitate them. Defining animal models without compromise which exclusively focus on what is possible in man will be a prerequisite for a successful iteration of the myriad of previously discovered modules and tools toward the generation of functional, mature replacement parts of the circulation. To what extent isolation models may be sufficient or more sophisticated methods may be required needs to be seen.

Overall, the re-introduction of a few forgotten principles could remove the glass ceiling that stood in the way of decades of scientific progress to move to the next level of clinical translation:

In the era of scientists and engineers having taken over the lead of most programs, modern young clinicians need to be reintegrated from the beginning to address the contemporary needs for cardiovascular tissue engineering rather than reiterate those of past decades.

Acknowledging the collective blind spot for healing modes will unfortunately be a sine qua non for succeeding.

At a time when multiple endovascular repeat interventions rather than open surgical revisions caused a paucity of experience and understanding of the patho-biology of prosthetic healing in humans a wealth of historical pathologist reports awaits to be re-discovered. The predominant materials influencing healing have hardly changed. The most sophisticated degradable leaflet materials used for tissue engineered transcatheter heart valves still largely rely on PET or PTFE for their skirts-the most likely entry path for regenerating tissue in man.

Once it is recognized what is possible and what is impossible with regards to clinical tissue regeneration it is likely that 
impasses will be overcome as the feasibility of the most likely healing modes in patients will guide every aspect of a program.

Once such steps have allowed to compare the numerous existing modules regarding their ability to lead to functional, fully endothelialised replacement tissue under the prevailing host conditions, the circle to the goal originally envisaged more than fifty years ago will be closed. This will still only conclude the feasibility phase of one of the great but most protracted developments in modern medicine. Yet, it will provide the impetus and focus to eventually carry this most exciting project of modern surgery to broad clinical fruition. It will be a late triumph for the

\section{REFERENCES}

1. Cooley DA, Mahaffey DE, De Bakey ME. Total excision of the aortic arch for aneurysm. Surg Gynecol Obstet. (1955) 101:667-72.

2. Kirklin JW, Dushane JW, Patrick RT, Donald DE, Hetzel PS, Harshbarger HG. Intracardiac surgery with the aid of a mechanical pump-oxygenator system (gibbon type): report of eight cases. Proc Staff Meet Mayo Clin. (1955) 30:201-6.

3. Melrose DG. A heart-lung machine for use in man. J Physiol. (1955) 127:513.

4. Melrose DG. The principles of heart-lung machines. Lect Sci Basis Med. (1956) 6:85-99.

5. Kirby CK, Johnson J. Aortic valve replacement for acquired aortic stenosis and insufficiency. Trans Am Soc Artif Intern Organs. (1961) 7:306-17.

6. Dillard DH, Vetto RR, Bruce RA, Merendino KA. Correction of aneurysm of the ascending aorta and of aortic insufficiency in Marfan's syndrome. Am J Surg. (1962) 104:337-46. doi: 10.1016/0002-9610(62)90336-7

7. Kolessov VI. Mammary artery-coronary artery anastomosis as method of treatment for angina pectoris. J Thorac Cardiovasc Surg. (1967) 54:535-44. doi: 10.1016/S0022-5223(19)43061-4

8. Szilagyi D, Smith R, Elliott J, Allen H. Long-term behavior of a dacron arterial substitute: clinical, roentgenologic and histologic correlations. Ann Surg. (1965) 162:453-77. doi: 10.1097/00000658-19650900000015

9. Suy R, Nevelteen A, Deleersnijder D, Dewaele G, Seghers K, Hendrickx J, et al. The expanded polytetrafluorethylene (PTFE) graft as a vascular substitute. J Cardiovasc Surg. (1980) 21:321-8.

10. Szycher M, Poirier V, Bernhard W, Franzblau C, Haudenschild C, Toselli P. Integrally textured polymeric surfaces for permanently implantable cardiac assist devices. Trans Am Soc Artif Intern Organs. (1980) 26:493-7.

11. Dasse KA, Chipman SD, Sherman CN, Levine AH, Frazier OH. Clinical experience with textured blood contacting surfaces in ventricular assist devices. ASAIO Trans. (1987) 33:418-25.

12. Akutsu T, Panayotopoulous EK, Topaz SR, Kolff WJ. A pneumatically driven intrathoracic artificial heart. Ann N Y Acad Sci. (1964) 120:766-72. doi: 10.1111/j.1749-6632.1964.tb34767.x

13. Nose Y, Phillips P, Kolff WJ. Problems with materials used in the intrathoracic artificial heart. Ann N Y Acad Sci. (1968) 146:271-88. doi: 10.1111/j.1749-6632.1968.tb20288.x

14. Rose A. Pathology of the formalin-treated heterograft porcine aortic valve in the mitral position. Thorax. (1972) 27:401-9. doi: 10.1136/thx.27.4.401

15. Albert HM, Bryant LR, Schechter FG. Seven year experience with mounted porcine valves. Ann Surg. (1977) 185:717-23. doi: 10.1097/00000658-197706000-00015

16. Carpentier A. From valvular xenograft to valvular bioprosthesis 1965-1977. Med Instrum. (1977) 11:98-101.

17. Jarvik R, Kessler T, McGill L, Olsen D, DeVries W, Deneris J, et al. Determinants of pannus formation in long-surviving artificial heart calves, and its prevention. Trans Am Soc Artif Intern Organs. (1981) 27:90-6. generations of surgeons and scientists involved-even if in the end, the majority of these implants will be deployed by interventional means rather than conventional cardiovascular surgery.

\section{AUTHOR CONTRIBUTIONS}

PZ wrote the paper. MD compiled the artificial heart chapter. ND compiled the myocardial regeneration chapter. DB compiled the synthetic scaffold chapter. TP oversaw the genesis of the manuscript. All authors contributed to the article and approved the submitted version.

18. Jarvik RK, Lawson JH, Olsen DB, Fukumasu H, Kolff WJ. The beat goes on: status of the artificial heart, 1977. Int J Artif Organs. (1978) 1:21-7.

19. Mosley J, Marston A. A 5 year follow-up of Dacron femoropopliteal bypass grafts. Br J Surg. (1986) 73:24-7. doi: 10.1002/bjs.1800730110

20. Ishihara T, Ferrans VJ, Jones M, Cabin HS, Roberts WC. Calcific deposits developing in a bovine pericardial bioprosthetic valve 3 days after implantation. Circulation. (1981) 63:718-23. doi: 10.1161/01.CIR.63.3.718

21. Bowen TE, Zajtchuk R, Brott WH, deCastro CM. Isolated mitral valve replacement with the Kay-Shiley prosthesis. Long-term followup and recommendations. J Thorac Cardiovasc Surg. (1980) 80:45-9. doi: 10.1016/S0022-5223(19)37826-2

22. Nuwayser E, Mansfield P, Wechezak A, Kahn R, Burkel W, Boatman J. Cultured linings for vascular assist devices. Trans Am Soc Artif Intern Organs. (1973) 19:168-74. doi: 10.1097/00002480-197301900-00031

23. Adachi M, Suzuki M, Kennedy J. Neointimas cultured in vitro for circulatory assist devices. I. Comparison of cultured cells derived from autologous tissues of various organs. J Surg Res. (1971) 11:483-91. doi: 10.1016/0022-4804(71)90065-5

24. Harasaki H, Kiraly R, Nose Y. Endothelialization in blood pumps. Trans Am Soc Artif Intern Organs. (1978) 24:415-25.

25. Dong E Jr, Griepp RB, Stinson EB, Shumway NE. Clinical transplantation of the heart. Ann Surg. (1972) 176:503-8. doi: 10.1097/00000658-197217640-00008

26. Nose Y, Tretbar LL, SenGupta A, Topaz SR, Kolff WJ. An artificial heart inside the chest. J Thorac Cardiovasc Surg. (1965) 50:792-9. doi: 10.1016/S0022-5223(19)33131-9

27. Kusserow BK. Artificial heart research-survey and prospectus. Trans N Y Acad Sci. (1965) 27:309-23. doi: 10.1111/j.2164-0947.1965.tb02200.x

28. Kolff WJ. An artificial heart inside the body. Sci Am. (1965) 213:39-46. doi: 10.1038/scientificamerican1165-38

29. Kolff WJ. Artificial Heart inside the Chest. Listing Res Cardiovasc Field. (1964) 10:652-5.

30. Galletti PM. Replacement of the heart with a mechanical device: the case of Dr. Barney Clark. N Engl J Med. (1984) 310:312-4. doi: 10.1056/NEJM198402023100509

31. Joyce LD, DeVries WC, Hastings WL, Olsen DB, Jarvik RK, Kolff WJ. Response of the human body to the first permanent implant of the Jarvik-7 total artificial heart. Trans Am Soc Artif Intern Organs. (1983) 29:81-7.

32. Adachi M, Suzuki M, Ross JJ, Wieting D, Kennedy J, De BM. Neointimas cultured in vitro for circulatory assistors. 3. Evaluation of antithrombogenic properties. J Thorac Cardiovasc Surg. (1973) 65:778-85. doi: 10.1016/S0022-5223(19)40714-9

33. Scott BT, Frazier O. Cellular linings of ventricular assist devices. Ann Thorac Surg. (1995) 60:1561-2. doi: 10.1016/0003-4975(95)00834-9

34. Bernhard WF, LaFarge CG, Robinson T, Yun I, Shirahige K, Kitrilakis S. An improved blood-pump interface for left-ventricular bypass. Ann Surg. (1968) 168:750-64. doi: 10.1097/00000658-196810000-00019

35. Rafii S, Oz M, Seldomridge J, Ferris B, Asch A, Nachman R, et al. Characterization of hematopoietic cells arising on the textured surface 
of left ventricular assist devices. Ann Thorac Surg. (1995) 60:1627-32. doi: 10.1016/0003-4975(95)00807-1

36. Spanier TB, Chen JM, Oz MC, Stern DM, Rose EA, Schmidt AM. Time-dependent cellular population of textured-surface left ventricular assist devices contributes to the development of a biphasic systemic procoagulant response. J Thorac Cardiovasc Surg. (1999) 118:404-13. doi: 10.1016/S0022-5223(99)70176-5

37. Veith FJ, Gupta SK, Ascer E, White-Flores S, Samson RH, Scher LA, et al. Six-year prospective multicenter randomized comparison of autologous saphenous vein and expanded polytetrafluoroethylene grafts in infrainguinal arterial reconstructions. J Vasc Surg. (1986) 3:104-14. doi: 10.1016/0741-5214(86)90073-X

38. Quinones-Baldrich WJ, Busuttil RW, Baker JD, Vescera CL, Ahn SS, Machleder $\mathrm{HI}$, et al. Is the preferential use of polytetrafluoroethylene grafts for femoropopliteal bypass justified? J Vasc Surg. (1988) 8:219-28. doi: 10.1016/0741-5214(88)90271-6

39. Jones JW, Ochsner JL, Mills NL, Hughes L. The internal mammary bypass graft: a superior second coronary artery. J Thorac Cardiovasc Surg. (1978) 75:625-31. doi: 10.1016/S0022-5223(19)41252-X

40. Tyras DH, Barner HB, Kaiser GC, Codd JE, Pennington DG, Willman VL. Bypass grafts to the left anterior descending coronary artery: saphenous vein versus internal mammary artery. J Thorac Cardiovasc Surg. (1980) 80:327-33. doi: 10.1016/S0022-5223(19)37757-8

41. Weyand M, Kerber S, Schmid C, Rolf N, Scheld HH. Coronary artery bypass grafting with an expanded polytetrafluoroethylene graft. Ann Thorac Surg. (1999) 67:1240-4. doi: 10.1016/S0003-4975(99)00168-X

42. Sapsford RN, Oakley GD, Talbot S. Early and late patency of expanded polytetrafluoroethylene vascular grafts in aorta-coronary bypass. $J$ Thorac Cardiovasc Surg. (1981) 81:860-4. doi: 10.1016/S0022-5223(19)3 9420-6

43. Merendino KA, Thomas GI, Jesseph JE, Herron PW, Winterscheid LC, Vetto RR. The open correction of rheumatic mitral regurgitation and/or stenosis; with special reference to regurgitation treated by posteromedial annuloplasty utilizing a pump-oxygenator. Ann Surg. (1959) 150:5-22. doi: 10.1097/00000658-19590700000001

44. Lillehei CW, Gott VL, Dewall RA, Varco RL. Surgical correction of pure mitral insufficiency by annuloplasty under direct vision. J Lancet. (1957) 77:446-9.

45. Lyons WS, Tompkins RG, Kirklin JW, Wood EH. Early and late hemodynamic effects of mitral commissurotomy. J Lab Clin Med. (1959) 53:499-516.

46. Mulder DG, Kattus AA, Longmire WP Jr. The treatment of acquired aortic stenosis by valvuloplasty. J Thorac Cardiovasc Surg. (1960) 40:731-43. doi: 10.1016/S0022-5223(19)32571-1

47. Garamella JJ, Cruz AB Jr, Heupel WH, Dahl JC, Jensen NK, Berman R. Ventricular septal defect with aortic insufficiencyl Successful surgical correction of both defects by the transaortic approach. Am J Cardiol. (1960) 5:266-72. doi: 10.1016/0002-9149(60)90208-3

48. Cabrol C, Cabrol A, Guiraudon G, Bertrand M. [Treatment of aortic insufficiency by means of aortic annuloplasty]. Arch Mal Coeur Vaiss. (1966) 59:1305-12.

49. Magilligan DJ Jr, Lewis JW Jr, Stein P, Alam M. The porcine bioprosthetic heart valve: experience at 15 years. Ann Thorac Surg. (1989) 48:324-9. doi: $10.1016 / 50003-4975(10) 62850-0$

50. Hanyu $\mathrm{Ni}, \mathrm{Xu} \mathrm{J}$. Recent trands in heart failure-related mortality: United States, 2000-2014. NCHS Data Brief. (2015) 231:1-8. Available online at: https://www.cdc.gov/nchs/data/databriefs/db231.pdf

51. Slaughter MS, Rogers JG, Milano CA, Russell SD, Conte JV, Feldman D, et al. Advanced heart failure treated with continuous-flow left ventricular assist device. N Engl J Med. (2009) 361:2241-51. doi: 10.1056/NEJMoa0909938

52. Baumann Kreuziger LM, Kim B, Wieselthaler GM. Antithrombotic therapy for left ventricular assist devices in adults: a systematic review. J Thromb Haemost. (2015) 13:946-55. doi: 10.1111/jth.12948

53. Rooke TW, Hirsch AT, Misra S, Sidawy AN, Beckman JA, Findeiss LK, et al. $2011 \mathrm{ACCF} / \mathrm{AHA}$ focused update of the guideline for the management of patients with peripheral artery disease (updating the 2005 guideline): a report of the American college of cardiology foundation/American heart association task force on practice guidelines: developed in collaboration with the society for cardiovascular angiography and interventions, society of interventional radiology, society for vascular medicine, and society for vascular surgery. J Vasc Surg. (2011) 54:e32-58. doi: 10.1016/j.jvs.2011.09.001

54. Jones WS, Dolor RJ, Hasselblad V, Vemulapalli S, Subherwal S, Schmit $\mathrm{K}$, et al. Comparative effectiveness of endovascular and surgical revascularization for patients with peripheral artery disease and critical limb ischemia: systematic review of revascularization in critical limb ischemia. Am Heart J. (2014) 167:489-98. doi: 10.1016/j.ahj.2013.12.012

55. Shayan M, Yang S, Ryu W, Chun Y. A novel low-profile thin-film nitinol/silk endograft for treating small vascular diseases. J Biomed Mater Res B Appl Biomater. (2017) 105:575-84. doi: 10.1002/jbm.b.33548

56. Liyanage T, Ninomiya T, Jha V, Neal B, Patrice HM, Okpechi I, et al. Worldwide access to treatment for end-stage kidney disease: a systematic review. Lancet. (2015) 385:1975-82. doi: 10.1016/S0140-6736(14)61601-9

57. Brescia MJ, Cimino JE, Appel K, Hurwich BJ. Chronic hemodialysis using venipuncture and a surgically created arteriovenous fistula. $N$ Engl J Med. (1966) 275:1089-92. doi: 10.1056/NEJM196611172752002

58. Kiyama H, Imazeki T, Kurihara S, Yoneshima H. Long-term follow-up of polyurethane vascular grafts for hemoaccess bridge fistulas. Ann Vasc Surg. (2003) 17:516-21. doi: 10.1007/s10016-003-0061-7

59. Arhuidese I, Reifsnyder T, Islam T, Karim O, Nejim B, Obeid T, et al. Bovine carotid artery biologic graft outperforms expanded polytetrafluoroethylene for hemodialysis access. J Vasc Surg. (2017) 65:775-82. doi: $10.1016 /$ j.jvs.2016.10.080

60. Mack MJ, Leon MB, Thourani VH, Makkar R, Kodali SK, Russo $\mathrm{M}$, et al. Transcatheter aortic-valve replacement with a balloonexpandable valve in low-risk patients. N Engl J Med. (2019) 380:1695-705. doi: 10.1056/NEJMoa1814052

61. Scherman J, Ofoegbu C, Myburgh A, Swanevelder J, van Breda B, Appa $\mathrm{H}$, et al. Preclinical evaluation of a transcatheter aortic valve replacement system for patients with rheumatic heart disease. EuroIntervention. (2019) 15:975-82. doi: 10.4244/EIJ-D-18-01052

62. Berndt N, Khan I, Gallo R. A complication in anticoagulation using lowmolecular weight heparin in a patient with a mechanical valve prosthesis. A case report. J Heart Valve Dis. (2000) 9:844-6.

63. Marelli AJ, Ionescu-Ittu R, Mackie AS, Guo L, Dendukuri N, Kaouache M. Lifetime prevalence of congenital heart disease in the general population from 2000 to 2010. Circulation. (2014) 130:749-56. doi: 10.1161/CIRCULATIONAHA.113.008396

64. Zilla P, Sliwa K, Morton Bolman R, Boateng P. Cardiac Surgery in low- to middle-income countries: (LMICs): a glimpse of hope. Cardiac Diagn Ther. (2019) 10:336-49. doi: 10.21037/cdt.2019.11.03

65. Zilla P, Yacoub M, Zühlke L, Beyersdorf F, Sliwa K, Khubulava G, et al. Global unmet needs in cardiac surgery. Global Heart. (2018) 13:293-303. doi: 10.1016/j.gheart.2018.08.002

66. Stone GW, Maehara A, Lansky AJ, de Bruyne B, Cristea E, Mintz GS, et al. A prospective natural-history study of coronary atherosclerosis. $\mathrm{N} \mathrm{Engl} \mathrm{J} \mathrm{Med.}$ (2011) 364:226-35. doi: 10.1056/NEJMoa1002358

67. Milasinovic D, Mohl W. Contemporary perspective on endogenous myocardial regeneration. World J Stem Cells. (2015) 7:793-805. doi: 10.4252 /wjsc.v7.i5.793

68. Gheorghiade M, Bonow RO. Chronic heart failure in the United States: a manifestation of coronary artery disease. Circulation. (1998) 97:282-9. doi: 10.1161/01.CIR.97.3.282

69. Ho KK, Anderson KM, Kannel WB, Grossman W, Levy D. Survival after the onset of congestive heart failure in framingham heart study subjects. Circulation. (1993) 88:107-15. doi: 10.1161/01.CIR.88.1.107

70. Lee DS, Schull MJ, Alter DA, Austin PC, Laupacis A, Chong A, et al. Early deaths in patients with heart failure discharged from the emergency department: a population-based analysis. Circ Heart Fail. (2010) 3:228-35. doi: 10.1161/CIRCHEARTFAILURE.109.885285

71. Alter DA, Ko DT, Tu JV, Stukel TA, Lee DS, Laupacis A, et al. The average lifespan of patients discharged from hospital with heart failure. J Gen Intern Med. (2012) 27:1171-9. doi: 10.1007/s11606-012-2072-y

72. Towbin JA, Lowe AM, Colan SD, Sleeper LA, Orav EJ, Clunie S, et al. Incidence, causes, and outcomes of dilated cardiomyopathy in children. JAMA. (2006) 296:1867-76. doi: 10.1001/jama.296.15.1867 
73. Ghidoni JJ, Liotta D, Adams JG, O'Neal RM, Hall CW. Implantation of autologous tissue fragments in velour fabric used to line cardoivascular prosheses: an in vivo culture system to produce cellular blood-prosthesis interfaces. J Biomed Mater Res. (1968) 2:201-8. doi: 10.1002/jbm.8200 20203

74. Mansfield P WA. Tissue-cultured cells as an endothelial lining of prosthetic material. In: Norman JC, editor. Organ Perfusion and Preservation. New York, NY: Appleton Century Crofts (1968). p. 189.

75. Bernhard WF, Husain M, George JB, Curtis GW. Fetal fibroblasts as a substratum for pseudoendothelial development on prosthetic surfaces. Surgery. (1969) 66:284-90.

76. Ghidoni JJ, Liotta D, Hall CW, Adams JG, Lechter A, Barrionueva M, et al. Healing of pseudointimas in velour-lined, impermeable arterial prostheses. Am J Pathol. (1968) 53:375-89.

77. Campbell JH, Campbell GR. Smooth muscle phenotypic modulationa personal experience. Arterioscler Thromb Vasc Biol. (2012) 32:1784-9. doi: 10.1161/ATVBAHA.111.243212

78. Ross R, Everett NB, Tyler R. Wound healing and collagen formation. VI. The origin of the wound fibroblast studied in parabiosis. J Cell Biol. (1970) 44:645-54. doi: 10.1083/jcb.44.3.645

79. Zilla P, Fasol R, Dudeck U, Siedler S, Preiss P, Fischlein T, et al. In situ cannulation, microgrid follow-up and low-density plating provide first passage endothelial cell masscultures for in vitro lining. J Vasc Surg. (1990) 12:180-9. doi: 10.1067/mva.1990.20844

80. Deutsch M, Meinhart J, Zilla P, Howanietz N, Gorlitzer M, Froeschl A, et al. Long-term experience in autologous in vitro endothelialization of infrainguinal ePTFE grafts. J Vasc Surg. (2009) 49:352-62. doi: 10.1016/j.jvs.2008.08.101

81. Cinti S. Transdifferentiation properties of adipocytes in the adipose organ. Am J Physiol Endocrinol Metab. (2009) 297:E977-86. doi: 10.1152/ajpendo.00183.2009

82. Kon K, Fujiwara T. Transformation of fibroblasts into endothelial cells during angiogenesis. Cell Tissue Res. (1994) 278:625-8. doi: $10.1007 / \mathrm{BF} 00331383$

83. DeRuiter M, Poelmann R, VanMunsteren J, Mironov V, Markwald R, Gittenberger DGA. Embryonic endothelial cells transdifferentiate into mesenchymal cells expressing smooth muscle actins in vivo and in vitro. Circ Res. (1997) 80:444-51. doi: 10.1161/01.RES.80.4.444

84. Arciniegas E, Neves CY, Carrillo LM, Zambrano EA, Ramirez R. Endothelial-mesenchymal transition occurs during embryonic pulmonary artery development. Endothelium. (2005) 12:193-200. doi: 10.1080/10623320500227283

85. Godoy M, Geuskens M, Van Marck EA, Borojevic R, Van Gansen P. Schistosomiasis and in vitro transdifferentiation of murine peritoneal macrophages into fibroblastic cells. Parasitol Res. (1989) 76:150-61. doi: 10.1007/BF00930838

86. Meng XM, Wang S, Huang XR, Yang C, Xiao J, Zhang Y, et al. Inflammatory macrophages can transdifferentiate into myofibroblasts during renal fibrosis. Cell Death Dis. (2016) 7:e2495. doi: 10.1038/cddis.2016.402

87. Feigl W, Susani M, Ulrich W, Matejka M, Losert U, Sinzinger H. Organisation of experimental thrombosis by blood cells. Evidence of the transformation of mononuclear cells into myofibroblasts and endothelial cells. Virchows Arch A Pathol Anat Histopathol. (1985) 406:133-48. doi: 10.1007/BF00737081

88. Chue WL, Campbell GR, Caplice N, Muhammed A, Berry CL, Thomas AC, et al. Dog peritoneal and pleural cavities as bioreactors to grow autologous vascular grafts. J Vasc Surg. (2004) 39:859-67. doi: 10.1016/j.jvs.2003.03.003

89. Campbell GR, Ryan GB. Origin of myofibroblasts in the avascular capsule around free-floating intraperitoneal blood clots. Pathology. (1983) 15:25364. doi: 10.3109/00313028309083503

90. Hoenig MR, Campbell GR, Rolfe BE, Campbell JH. Tissue-engineered blood vessels: alternative to autologous grafts? Arterioscler Thromb Vasc Biol. (2005) 25:1128-34. doi: 10.1161/01.ATV.0000158996.03867.72

91. Campbell JH, Efendy JL, Campbell GR. Novel vascular graft grown within recipient's own peritoneal cavity. Circ Res. (1999) 85:1173-8. doi: 10.1161/01.RES.85.12.1173

92. Lopes-Coelho F, Silva F, Gouveia-Fernandes S, Martins C, Lopes N, Domingues $\mathrm{G}$, et al. Monocytes as endothelial progenitor cells (EPCs), another brick in the wall to disentangle tumor angiogenesis. Cells. (2020) 9:107. doi: 10.3390/cells9010107

93. Guilak F, Butler DL, Goldstein SA, Baaijens FP. Biomechanics and mechanobiology in functional tissue engineering. J Biomech. (2014) 47:193340. doi: 10.1016/j.jbiomech.2014.04.019

94. Zilla P, Wolf M, Rafiee N, Moodley L, Bezuidenhout D, Black M, et al. Utilization of shape memory in external vein-graft meshes allows extreme diameter constriction for suppressing intimal hyperplasia: a non-human primate study. J Vasc Surg. (2009) 49:1532-42. doi: 10.1016/j.jvs.2009.01.068

95. Zilla P, Moodley L, Wolf MF, Bezuidenhout D, Sirry MS, Rafiee N, et al. Knitted nitinol represents a new generation of constrictive external vein graft meshes. J Vasc Surg. (2011) 54:1439-50. doi: 10.1016/j.jvs.2011.05.023

96. Zilla P, Moodley L, Scherman J, Krynauw H, Kortsmit J, Human $\mathrm{P}$, et al. Remodeling leads to distinctly more intimal hyperplasia in coronary than in infrainguinal vein grafts. J Vasc Surg. (2012) 55:1734-41. doi: 10.1016/j.jvs.2011.11.057

97. Zilla P, Human P, Wolf M, Lichtenberg W, Rafiee N, Bezuidenhout D, et al. Constrictive external nitinol meshes inhibit vein graft intimal hyperplasia in nonhuman primates. J Thorac Cardiovasc Surg. (2008) 136:717-25. doi: 10.1016/j.jtcvs.2008.02.068

98. Moodley L, Franz T, Human P, Wolf MF, Bezuidenhout D, Scherman J, et al. Protective constriction of coronary vein grafts with knitted nitinol. Eur J Cardiothorac Surg. (2013) 44:64-71. doi: 10.1093/ejcts/ezs670

99. Kutikhin AG, Sinitsky MY, Yuzhalin AE, Velikanova EA. Shear stress: an essential driver of endothelial progenitor cells. J Mol Cell Cardiol. (2018) 118:46-69. doi: 10.1016/j.yjmcc.2018.03.007

100. Song MJ, Dean D, Knothe Tate ML. Mechanical modulation of nascent stem cell lineage commitment in tissue engineering scaffolds. Biomaterials. (2013) 34:5766-75. doi: 10.1016/j.biomaterials.2013.04.023

101. Potter CM, Lao KH, Zeng L, Xu Q. Role of biomechanical forces in stem cell vascular lineage differentiation. Arterioscler Thromb Vasc Biol. (2014) 34:2184-90. doi: 10.1161/ATVBAHA.114.303423

102. Zilla P, Bezuidenhout D, Human P. Prosthetic vascular grafts: wrong models, wrong questions and no healing. Biomaterials. (2007) 28:5009-27. doi: 10.1016/j.biomaterials.2007.07.017

103. Engler AJ, Sen S, Sweeney HL, Discher DE. Matrix elasticity directs stem cell lineage specification. Cell. (2006) 126:677-89. doi: 10.1016/j.cell.2006. 06.044

104. Shinoka T, Breuer CK, Tanel RE, Zund G, Miura T, Ma PX, et al. Tissue engineering heart valves: valve leaflet replacement study in a lamb model. Ann Thorac Surg. (1995) 60 (6 Suppl):S513-6. doi: 10.1016/0003-4975(95)00733-4

105. Shinoka T, Ma PX, Shum-Tim D, Breuer CK, Cusick RA, Zund G, et al. Tissue-engineered heart valves. Autologous valve leaflet replacement study in a lamb model. Circulation. (1996) 94 (9 Suppl):II164-8.

106. Szafron JM, Khosravi R, Reinhardt J, Best CA, Bersi MR, Yi T, et al. Immuno-driven and mechano-mediated neotissue formation in tissue engineered vascular grafts. Ann Biomed Eng. (2018) 46:1938-50. doi: 10.1007/s10439-018-2086-7

107. Berger K, Sauvage LR, Rao AM, Wood SJ. Healing of arterial prostheses in man: its incompleteness. Ann Surg. (1972) 175:118-27. doi: 10.1097/00000658-197201000-00018

108. Wesolowski SA, Fries CC, Hennigar G, Fox LM, Sawyer PN, Sauvage LR. Factors contributing to long-term failures in human vascular prosthetic grafts. J Cardiovasc Surg. (1964) 5:544-67.

109. Debakey ME, Jordan GL Jr, Abbott JP, Halpert B, O’Neal RM. The fate of dacron vascular grafts. Arch Surg. (1964) 89:757-82. doi: 10.1001/archsurg.1964.01320050001001

110. Pennel T, Zilla P, Bezuidenhout D. Differentiating transmural from transanastomotic prosthetic graft endothelialization through an isolation loop-graft model. J Vasc Surg. (2013) 58:1053-61. doi: 10.1016/j.jvs.2012.11.093

111. Hess F, Steeghs S, Jerusalem C. Neointima formation in expanded polytetrafluoroethylene vascular grafts with different fibril lengths following implantation in the rat aorta. Microsurgery. (1989) 10:47-52. doi: $10.1002 /$ micr.1920100109

112. Bezuidenhout D DN, Wolf M, Zilla P. High porosity vascular grafts: Polyurethane versus ePTFE in the senescent primate model. In: $9^{\text {th }}$ Biennial 
Meeting of the International Society of Applied Cardiovascular Biology (ISACB) (Savannah, GA) (2004). 41p.

113. Pennel T, Bezuidenhout D, Koehne J, Davies NH, Zilla P. Transmural capillary ingrowth is essential for confluent vascular graft healing. Acta Biomater. (2018) 65: 237-47. doi: 10.1016/j.actbio.2017.10.038

114. Stump M, Jordan G, DeBakey M. Endothelium growth from circulating blood on isolated intravascular dacron hub. Amer J Path. (1963) 43:361-68.

115. Hertzer N. Regeneration of endothelium in knitted and velour dacron vascular grafts in dogs. J Cardiovasc Surg. (1981) 22:223-30.

116. Shi Q, Wu MH, Onuki Y, Ghali R, Hunter GC, Johansen KH, et al. Endothelium on the flow surface of human aortic dacron vascular grafts. J Vasc Surg. (1997) 25:736-42. doi: 10.1016/S0741-5214(97)70303-3

117. Shi Q, Wu M, Hayashida N, Wechezak A, Clowes A, Sauvage L. Proof of fallout endothelialization of impervious dacron grafts in the aorta and inferior vena cava of the dog. J Vasc Surg. (1994) 20:546-56. doi: 10.1016/0741-5214(94)90279-8

118. Onuki Y, Kouchi Y, Yoshida H, Wu MH, Shi Q, Sauvage LR. Early presence of endothelial-like cells on the flow surface of porous arterial prostheses implanted in the descending thoracic aorta of the dog. Ann Vasc Surg. (1997) 11:604-11. doi: 10.1007/s100169900098

119. Zhang Z, Briana S, Douville Y, Zhao H, Gilbert N. Transmural communication at a sub cellular level may play a critical role in the fallout based endothelialization of Dacron vascular prostheses in canine. J Biomed Mat Res. (2007) 81A:877-87. doi: 10.1002/jbm.a.31124

120. Wu M, Shi Q, Wechezak A, Clowes A, Gordon I, Sauvage L. Definitive proof of endothelialization of a dacron arterial prosthesis in a human being. J Vasc Surg. (1995) 21:862-7. doi: 10.1016/S0741-5214(05)80019-9

121. Shi Q, Bhattacharya V, Hong-De Wu M, Sauvage LR. Utilizing granulocyte colony-stimulating factor to enhance vascular graft endothelialization from circulating blood cells. Ann Vasc Surg. (2002) 16:314-20. doi: 10.1007/s10016-001-0238-x

122. Florey HW, Greer SJ, Kiser J, Poole JC, Telander R, Werthessen NT. The development of the pseudointima lining fabric grafts of the aorta. Br J Exp Pathol. (1962) 43:655-60.

123. Clowes A, Kirkman T, Reidy M. Mechanisms of arterial graft healing. Rapid transmural capillary ingrowth provides a source of intimal endothelium and smooth muscle in porous PTFE prostheses. Am J Pathol. (1986) 123:220-30.

124. Zacharias R, Kirkman T, Clowes A. Mechanisms of healing in synthetic grafts. J Vasc Surg. (1987) 6:429-36. doi: 10.1067/mva.1987.avs0060429

125. Golden M, Hanson S, Kirkman T, Schneider P, Clowes A. Healing of polytetrafluoroethylene arterial grafts is influenced by graft porosity. J Vasc Surg. (1990) 11:838-44. doi: 10.1067/mva.1990. 18047

126. Bezuidenhout DVM, Davies N, Schilling L, Fittkau M, Zilla P. Small diameter vascular grafts: a Meaningful model at last. In: Towards Biofunctional Cardiovascular Implants Scientific Program Book - 9th Biennial Meeting. (Savannah, GA: International Society for Applied Cardiovascular Biology (ISACB)) (2004) 58p.

127. Wu MH, Shi Q, Onuki Y, Kouchi Y, Sauvage LR. Histologic observation of continuity of transmural microvessels between the perigraft vessels and flow surface microostia in a porous vascular prosthesis. Ann Vasc Surg. (1996) 10:11-5. doi: 10.1007/BF02002335

128. Hirschi KK, Rohovsky SA, D’Amore PA. Cell-cell interactions in vessel assembly: a model for the fundamentals of vascular remodelling. Transpl Immunol. (1997) 5:177-8. doi: 10.1016/S0966-3274(97)80034-2

129. Sedlarik KM, van Wachem PB, Bartels H, Schakenraad JM. Rapid endothelialization of microporous vascular prostheses covered with meshed vascular tissue: a preliminary report. Biomaterials. (1990) 11:4-8. doi: 10.1016/0142-9612(90)90043-P

130. Bull DA, Hunter GC, Holubec H, Aguirre ML, Rappaport WD, Putnam CW. Cellular origin and rate of endothelial cell coverage of PTFE grafts. J Surg Res. (1995) 58:58-68. doi: 10.1006/jsre.1995.1010

131. Sterpetti A, Hunter W, Schultz R, Farina C. Healing of high-porosity polytetrafluoroethylene arterial grafts is influenced by the nature of the surrounding tissue. Surgery. (1992) 111:677-82.

132. DeBakey M, Jordan GJ, Beall A, O'Neal R, Abbott J, Halpert B. Basic biologic reactions to vascular grafts and prostheses. Surg Clin North Am. (1965) 45:477-97. doi: 10.1016/S0039-6109(16)37544-2
133. Collet JP, Park D, Lesty C, Soria J, Soria G, Montalescot G, Weisel JW. Influence of fibrin network conformation and fibrin fibre diameter on fibrinolysis speed. Arteriocler Thromb Bill. (2000) 20:1354-61. doi: 10.1161/01.atv.20.5.1354

134. Wesolowski S, Fries C, Karlson K, Debakey M, Sawyer P. Porosity: primary determinant of ultimate fate of synthetic vascular grafts. Surgery. (1961) 50:91-6.

135. Clowes A, Zacharias R, Kirkman T. Early endothelial coverage of synthetic arterial grafts: porosity revisited. Am J Surg. (1987) 153:501-4. doi: 10.1016/0002-9610(87)90802-6

136. Crane C. Arteriosclerotic aneurysm of the abdominal aorta; some pathological and clinical correlations. N Engl J Med. (1955) 253:954-8. doi: 10.1056/NEJM195512012532202

137. Nehls V, Herrmann R. The configuration of fibrin clots determines capillary morphogenesis and endothelial cell migration. Microvasc Res. (1996) 51:34764. doi: 10.1006/mvre. 1996.0032

138. Herbert C, Nagaswami C, Bittner G, Hubbell J, Weisel J. Effects of fibrin micromorphology on neurite growth from dorsal root ganglia cultured in three-dimensional fibrin gels. J Biomed Mater Res. (1998) 40:551-9. doi: 10. 1002/(SICI)1097-4636(19980615)40:4<551::AID-JBM6>3.0.CO;2-E

139. Ghidoni J, Liotta D, Hall C, O'Neal R, De BM. Production of cellular linings in impermeable velour-lined cardiovascular prostheses: growth from implanted tissue fragments. Surgery. (1969) 65:70-7.

140. Herring M, Gardner A, Glover J. A single-staged technique for seeding vascular grafts with autogenous endothelium. Surgery. (1978) 84:498-504.

141. Graham L, Vinter D, Ford J, Kahn R, Burkel W, Stanley J. Endothelial cell seeding of prosthetic vascular grafts: early experimental studies with cultured autologous canine endothelium. Arch Surg. (1980) 115:929-33. doi: 10.1001/archsurg.1980.01380080025005

142. Herring M, Smith J, Dalsing M, Glover J, Compton R, Etchberger K, et al. Endothelial seeding of polytetrafluoroethylene femoral popliteal bypasses: the failure of low-density seeding to improve patency. J Vasc Surg. (1994) 20:650-5. doi: 10.1016/0741-5214(94)90291-7

143. Gu YD, Zhang GM, Zhang LY, Li FG, Jiang JF. Clinical and experimental studies of cigarette smoking in microvascular tissue transfers. Microsurgery. (1993) 14:391-7. doi: 10.1002/micr.1920140608

144. Zilla P, Siedler S, Fasol R, Sharefkin J. Reduced reproductive capacity of freshly harvested endothelial cells in smokers: a possible shortcoming in the success of seeding? J Vasc Surg. (1989) 10:143-8. doi: 10.1016/0741-5214(89) 90347-9

145. Herring M, Gardner A, Glover J. Seeding human arterial prostheses with mechanically derived endothelium. The detrimental effect of smoking. $J$ Vasc Surg. (1984) 1:279-89. doi: 10.1016/0741-5214(84)90059-4

146. Meinhart J, Deutsch M, Zilla P. Risk factors for autologous endothelial cell cultures. In: Zilla P, Greisler H, editors, Tissue Engineering of Prosthetic Vascular Grafts. Austin: RG Landes (1999). p. 167-71.

147. Meinhart J, Halbmeyer W, Deutsch M, Zilla P. Hyperlipidemia coincides with reversible growth impairment of cultured human autologous endothelial cells. Endothelium. (2002) 9:239-46. doi: $10.1080 / 10623320214740$

148. Williams SK, Rose DG, Jarrell BE. Microvascular endothelial cell sodding of ePTFE vascular grafts: improved patency and stability of the cellular lining. $J$ Biomed Mater Res. (1994) 28:203-12. doi: 10.1002/jbm.820280210

149. Rupnick MA, Hubbard FA, Pratt K, Jarrell BE, Williams SK. Endothelialization of vascular prosthetic surfaces after seeding or sodding with human microvascular endothelial cells. J Vasc Surg. (1989) 9:788-95. doi: 10.1016/0741-5214(89)90086-4

150. Noishiki Y, Tomizawa Y, Yamane Y, Matsumoto A. Autocrine angiogenic vascular prosthesis with bone marrow transplantation. Nat Med. (1996) 2:90-3. doi: 10.1038/nm0196-90

151. Hibino N, Shin'oka T, Matsumura G, Ikada Y, Kurosawa H. The tissueengineered vascular graft using bone marrow without culture. $J$ Thorac Cardiovasc Surg. (2005) 129:1064-70. doi: 10.1016/j.jtcvs.2004.10.030

152. Williams SK, Schneider T, Kapelan B, Jarrell BE. Formation of a functional endothelium on vascular grafts. J Electron Microsc Tech. (1991) 19:439-51. doi: 10.1002/jemt.1060190406

153. Pasic M, Muller-Glauser W, von Segesser L, Odermatt B, Lachat M, Turina M. Endothelial cell seeding improves patency of synthetic vascular grafts: 
manual versus automatized method. Eur J Cardiothorac Surg. (1996) 10:3729. doi: 10.1016/S1010-7940(96)80097-2

154. Baitella EG, Groscurth P, Zilla P, Lachat M, Muller GW, Schneider J, et al. Long-term results of tissue development and cell differentiation on dacron prostheses seeded with microvascular cells in dogs. J Vasc Surg. (1993) 18:1019-28. doi: 10.1016/0741-5214(93)90557-3

155. Williams SK, Morris ME, Kosnik PE, Lye KD, Gentzkow GD, Ross CB, et al. Point-of-care adipose-derived stromal vascular fraction cell isolation and expanded polytetrafluoroethylene graft sodding. Tissue Eng Part C Methods. (2017) 23:497-504. doi: 10.1089/ten.tec.2017.0105

156. Watanabe M, Shin'oka T, Tohyama S, Hibino N, Konuma T, Matsumura G, et al. Tissue-engineered vascular autograft: inferior vena cava replacement in a dog model. Tissue Eng. (2001) 7:429-39. doi: 10.1089/10763270152436481

157. Matsumura G, Hibino N, Ikada Y, Kurosawa H, Shin'oka T. Successful application of tissue engineered vascular autografts: clinical experience. Biomaterials. (2003) 24:2303-8. doi: 10.1016/S0142-9612(03)00043-7

158. Fioretta ES, Lintas V, Mallone A, Motta SE, von Boehmer L, Dijkman PE, et al. Differential leaflet remodeling of bone marrow cell pre-seeded versus nonseeded bioresorbable transcatheter pulmonary valve replacements. JACC Basic Transl Sci. (2020) 5:15-31. doi: 10.1016/j.jacbts.2019.09.008

159. Sugiura T, Matsumura G, Miyamoto S, Miyachi H, Breuer CK, Shinoka T. Tissue-engineered vascular grafts in children with congenital heart disease: intermediate term follow-up. Semin Thorac Cardiovasc Surg. (2018) 30:1759. doi: 10.1053/j.semtcvs.2018.02.002

160. Best C, Tara S, Wiet M, Reinhardt J, Pepper V, Ball M, et al. Deconstructing the Tissue engineered vascular graft: evaluating scaffold pre-wetting, conditioned media incubation, and determining the optimal mononuclear cell source. ACS Biomater Sci Eng. (2017) 3:1972-9. doi: 10.1021/acsbiomaterials.6b00123

161. Lee YU, Mahler N, Best CA, Tara S, Sugiura T, Lee AY, et al. Rational design of an improved tissue-engineered vascular graft: determining the optimal cell dose and incubation time. Regen Med. (2016) 11:159-67. doi: 10.2217/rme.15.85

162. Stacy MR, Best CA, Maxfield MW, Qiu M, Naito Y, Kurobe H, et al. Magnetic resonance imaging of shear stress and wall thickness in tissueengineered vascular grafts. Tissue Eng Part C Methods. (2018) 24:465-73. doi: $10.1089 /$ ten.tec.2018.0144

163. Niklason LE, Gao J, Abbott WM, Hirschi KK, Houser S, Marini R, et al. Functional arteries grown in vitro. Science. (1999) 284:489-93. doi: $10.1126 /$ science.284.5413.489

164. Shin'oka T, Matsumura G, Hibino N, Naito Y, Watanabe M, Konuma T, et al. Midterm clinical result of tissue-engineered vascular autografts seeded with autologous bone marrow cells. J Thorac Cardiovasc Surg. (2005) 129:1330-8. doi: 10.1016/j.jtcvs.2004.12.047

165. O'Donohoe MK, Schwartz LB, Radic ZS, Mikat EM, McCann RL, Hagen PO. Chronic ACE inhibition reduces intimal hyperplasia in experimental vein grafts. Ann Surg. (1991) 214:727-32. doi: 10.1097/00000658-199112000-00014

166. Ruiz-Rosado JD, Lee YU, Mahler N, Yi T, Robledo-Avila F, MartinezSaucedo D, et al. Angiotensin II receptor I blockade prevents stenosis of tissue engineered vascular grafts. FASEB J. (2018) 32:6822-32. doi: 10.1096/fj.201800458

167. Emmert MY, Weber B, Behr L, Sammut S, Frauenfelder T, Wolint P, et al. Transcatheter aortic valve implantation using anatomically oriented, marrow stromal cell-based, stented, tissue-engineered heart valves: technical considerations and implications for translational cell-based heart valve concepts. Eur J Cardiothorac Surg. (2014) 45:61-8. doi: 10.1093/ejcts/ezt243

168. Emmert MY, Weber B, Wolint P, Behr L, Sammut S, Frauenfelder $\mathrm{T}$, et al. Stem cell-based transcatheter aortic valve implantation: first experiences in a pre-clinical model. JACC Cardiovasc Interv. (2012) 5:874-83. doi: 10.1016/j.jcin.2012.04.010

169. Orlic D, Kajstura J, Chimenti S, Jakoniuk I, Anderson SM, Li B, et al. Bone marrow cells regenerate infarcted myocardium. Nature. (2001) 410:701-5. doi: $10.1038 / 35070587$

170. Assmus B, Schachinger V, Teupe C, Britten M, Lehmann R, Dobert N, et al. Transplantation of progenitor cells and regeneration enhancement in acute myocardial infarction (TOPCARE-AMI). Circulation. (2002) 106:3009-17. doi: 10.1161/01.CIR.0000043246.74879.CD
171. Strauer BE, Brehm M, Zeus T, Kostering M, Hernandez A, Sorg RV, et al. Repair of infarcted myocardium by autologous intracoronary mononuclear bone marrow cell transplantation in humans. Circulation. (2002) 106:1913-8. doi: 10.1161/01.CIR.0000034046.87607.1C

172. Murry CE, Soonpaa MH, Reinecke H, Nakajima H, Nakajima HO, Rubart $\mathrm{M}$, et al. Haematopoietic stem cells do not transdifferentiate into cardiac myocytes in myocardial infarcts. Nature. (2004) 428:664-8. doi: 10.1038 /nature 02446

173. Fisher SA, Doree C, Mathur A, Martin-Rendon E. Meta-analysis of cell therapy trials for patients with heart failure. Circ Res. (2015) 116:1361-77. doi: 10.1161/CIRCRESAHA.116.304386

174. Gyongyosi M, Wojakowski W, Lemarchand P, Lunde K, Tendera M, Bartunek J, et al. Meta-Analysis of cell-based CaRdiac stUdiEs (ACCRUE) in patients with acute myocardial infarction based on individual patient data. Circ Res. (2015) 116:1346-60. doi: 10.1161/CIRCRESAHA.116.304346

175. Davies NGK, Ngoepe M, Franz T, Lecour S. Delivery modes for cardiac stem cell therapy. In: Madonna R, editor. Stem Cells and Cardiac Regeneration. New York, NY: Springer International Publishing (2016). p. 165-90.

176. Weinberger F, Mannhardt I, Eschenhagen T. Engineering cardiac muscle tissue: a maturating field of research. Circ Res. (2017) 120:1487-500. doi: 10.1161/CIRCRESAHA.117.310738

177. Fujita B, Zimmermann WH. Myocardial tissue engineering strategies for heart repair: current state of the art. Interact Cardiovasc Thorac Surg. (2018) 27:916-20. doi: 10.1093/icvts/ivy208

178. Wolint P, Bopp A, Woloszyk A, Tian Y, Evrova O, Hilbe M, et al. Cellular self-assembly into $3 \mathrm{D}$ microtissues enhances the angiogenic activity and functional neovascularization capacity of human cardiopoietic stem cells. Angiogenesis. (2019) 22:37-52. doi: 10.1007/s10456-018-9635-4

179. Emmert MY, Wolint P, Winklhofer S, Stolzmann P, Cesarovic N, Fleischmann $\mathrm{T}$, et al. Transcatheter based electromechanical mapping guided intramyocardial transplantation and in vivo tracking of human stem cell based three dimensional microtissues in the porcine heart. Biomaterials. (2013) 34:2428-41. doi: 10.1016/j.biomaterials.2012. 12.021

180. Kadner K, Dobner S, Franz T, Bezuidenhout D, Sirry MS, Zilla P, et al. The beneficial effects of deferred delivery on the efficiency of hydrogel therapy post myocardial infarction. Biomaterials. (2012) 33:2060-6. doi: 10.1016/j.biomaterials.2011.11.031

181. Ciuffreda MC, Malpasso G, Chokoza C, Bezuidenhout D, Goetsch KP, Mura $\mathrm{M}$, et al. Synthetic extracellular matrix mimic hydrogel improves efficacy of mesenchymal stromal cell therapy for ischemic cardiomyopathy. Acta Biomater. (2018) 70:71-83. doi: 10.1016/j.actbio.2018.01.005

182. Diaz M. Christman KL. Injectable hydrogels to treat myocardial infarction. In: Serpooshan VS, Wu M, editors. Cardiovascular Regenerative Medicine: Tissue Engineering and Clinical Applications. New York, NY: Springer International Publishing (2019). p. 185-206.

183. Dobner S, Bezuidenhout D, Govender P, Zilla P, Davies N. A synthetic non-degradable polyethylene glycol hydrogel retards adverse postinfarct left ventricular remodeling. J Card Fail. (2009) 15:629-36. doi: 10.1016/j.cardfail.2009.03.003

184. David W, Wold LE, Dow JS, Kloner RA. Thickening of the infarcted wall by collagen injection improves left ventricular function in rats. J Am Coll Cardiol. (2005) 46:714-19. doi: 10.1016/j.jacc.2005. 04.056

185. Wall ST, Walker JC, Healy KE, Ratcliffe MB, Guccione JM. Theoretical impact of the injection of material into the myocardium: a finite element model simulation. Circulation. (2006) 114:2627-35. doi: 10.1161/CIRCULATIONAHA.106.6 57270

186. Miller R, Davies NH, Kortsmit J, Zilla P, Franz T. Outcomes of myocardial infarction hydrogel injection therapy in the human left ventricle dependent on injectate distribution. Int J Numer Method Biomed Eng. (2013) 29:870-84. doi: $10.1002 / \mathrm{cnm} .2551$

187. Opie LH, Commerford PJ, Gersh BJ, Pfeffer MA. Controversies in ventricular remodelling. Lancet. (2006) 367:356-67. doi: 10.1016/S0140-6736(06)68074-4

188. Marban E. A mechanistic roadmap for the clinical application of cardiac cell therapies. Nat Biomed Eng. (2018) 2:353-61. doi: 10.1038/s41551-018-0216-Z 
189. Menasche P. Cardiac cell therapy: current status, challenges and perspectives. Arch Cardiovasc Dis. (2020) 113:285-92. doi: 10.1016/j.acvd.2020.01.002

190. Antes TJ, Middleton RC, Luther KM, Ijichi T, Peck KA, Liu WJ, et al. Targeting extracellular vesicles to injured tissue using membrane cloaking and surface display. J Nanobiotechnology. (2018) 16:61. doi: 10.1186/s12951-018-0388-4

191. Frangogiannis NG. The extracellular matrix in myocardial injury, repair, and remodeling. J Clin Invest. (2017) 127:1600-12. doi: 10.1172/JCI87491

192. Lu L, Gunja-Smith Z, Woessner JF, Ursell PC, Nissen T, Galardy RE, et al. Matrix metalloproteinases and collagen ultrastructure in moderate myocardial ischemia and reperfusion in vivo. Am J Physiol Heart Circ Physiol. (2000) 279:H601-9. doi: 10.1152/ajpheart.2000.279.2.H601

193. Frangogiannis NG. The extracellular matrix in ischemic and nonischemic heart failure. Circ Res. (2019) 125:117-46. doi: 10.1161/CIRCRESAHA.119.311148

194. Schaper W, Flameng W, Winkler B, Wusten B, Turschmann W, Neugebauer G, et al. Quantification of collateral resistance in acute and chronic experimental coronary occlusion in the dog. Circ Res. (1976) 39:371-7. doi: 10.1161/01.RES.39.3.371

195. Prifti E, Di Lascio G, Harmelin G, Bani D, Briganti V, Veshti A, et al. Cellular cardiomyoplasty into infracted swine's hearts by retrograde infusion through the venous coronary sinus: an experimental study. Cardiovasc Revasc Med. (2016) 17:262-71. doi: 10.1016/j.carrev.2016.02.008

196. Zhang Y, Zhu D, Wei Y, Wu Y, Cui W, Liuqin L, et al. A collagen hydrogel loaded with HDAC7-derived peptide promotes the regeneration of infarcted myocardium with functional improvement in a rodent model. Acta Biomater. (2019) 86:223-34. doi: 10.1016/j.actbio.2019.01.022

197. Maruyama Y. The human endothelial cell in tissue culture. $Z$ Zellforsch Mikrosk Anat. (1963) 60:69-79. doi: 10.1007/BF003 29383

198. Wechezak AR, Viggers RF, Sauvage LR, Mansfield PB. Endothelial cell rounding associated with long-term implantations of left ventricular assist devices. Scan Electron Microsc. (1984) (Pt. 3):1353-60.

199. Fasol R, Zilla P, Groscurth P, Wolner E, Moser R. Experimental in vitro cultivation of human endothelial cells on artificial surfaces. Trans Am Soc Artif Intern Organs. (1985) 31:276-83.

200. Zilla P, Fasol R, Grimm M, Fischlein T, Eberl T, Preiss P, et al. Growth properties of cultured human endothelial cells on differently coated artificial heart materials. J Thorac Cardiovasc Surg. (1991) 101:671-80. doi: 10.1016/S0022-5223(19)36698-X

201. Fasol R, Zilla P, Deutsch M, Fischlein T, Kadletz M, Griesmacher A, et al. Endothelialization of artificial surfaces: does surface tension determine in vitro growth of human saphenous vein endothelial cells? Tex Heart Inst J. (1987) 14:119-26.

202. Zilla P, Fasol R, Deutsch M, Fischlein T, Minar E, Hammerle A, et al. Endothelial cell seeding of polytetrafluoroethylene vascular grafts in humans: a preliminary report. J Vasc Surg. (1987) 6:535-41. doi: 10.1067/mva.1987.avs0060535

203. Fasol R, Zilla P, Deutsch M, Grimm M, Fischlein T, Laufer G. Human endothelial cell seeding: evaluation of its effectiveness by platelet parameters after one year. J Vasc Surg. (1989) 9:432-6. doi: 10.1016/S0741-5214(89)70006-9

204. Kaehler J, Zilla P, Fasol R, Deutsch M, Kadletz M. Precoating substrate and surface configuration determine adherence and spreading of seeded endothelial cells on polytetrafluoroethylene grafts. J Vasc Surg. (1989) 9:53541. doi: 10.1016/0741-5214(89)90469-2

205. Kadletz M, Moser R, Preiss P, Deutsch M, Zilla P, Fasol R. In vitro lining of fibronectin coated PTFE grafts with cryopreserved saphenous vein endothelial cells. Thorac Cardiovasc Surg. (1987) 35:143-7. doi: 10.1055/s-2007-1020277

206. Zilla P, Fasol R, Preiss P, Kadletz M, Deutsch M, Schima H, et al. Use of fibrin glue as a substrate for in vitro endothelialization of PTFE vascular grafts. Surgery. (1989) 105:515-22.

207. Zilla P, Preiss P, Groscurth P, Rosemeier F, Deutsch M, Odell J, et al. In vitro-lined endothelium: initial integrity and ultrastructural events. Surgery. (1994) 116:524-34.

208. Fasol RZP, Preiss P, von Oppell U, Odell J, Reichart B. Allogenic, multidonor in vitro endothelialization of small diameter PTFE grafts in baboons. Vasc Surg. (1991) 25:64-71. doi: 10.1177/1538574491025 00111

209. Zilla P, von Oppell U, Deutsch M. The endothelium: a key to the future. J Card Surg. (1993) 8:32-60. doi: 10.1111/j.1540-8191.1993.tb 00574.x

210. Deutsch M, Eberl T, Fischlein T, Meinhart J, Minar E, Puschmann R, et al. [In vitro endothelialization of ePTFE vascular prostheses in clinical use: preliminary results]. Vasa Suppl. (1990) 30:219-20.

211. Zilla P, Deutsch M, Meinhart J, Puschmann R, Eberl T, Minar E, et al. Clinical in vitro endothelialization of femoropopliteal bypass grafts: an actuarial follow-up over three years. J Vasc Surg. (1994) 19:540-8. doi: 10.1016/S0741-5214(94)70083-4

212. Deutsch M, Meinhart J, Fischlein T, Hofmann G, Zilla P. Long term effects of clinical in-vitro endothelializatio on grafts. J Vasc Surg. (1997) 25:1110-2.

213. Meinhart J, Deutsch M, Zilla P. Eight years of clinical endothelial cell transplantation. Closing the gap between prosthetic grafts and vein grafts. ASAIO J. (1997) 43:515-21. doi: 10.1097/00002480-199709000-00034

214. Deutsch M, Meinhart J, Fischlein T, Preiss P, Zilla P. Clinical autologous in vitro endothelialization of infrainguinal ePTFE grafts in 100 patients: a 9-year experience. Surgery. (1999) 126:847-55. doi: 10.1016/S0039-6060(99)70025-5

215. Meinhart J, Deutsch M, Fischlein T, Howanietz N, Froschl A, Zilla P. Clinical autologous in vitro endothelialization of 153 infrainguinal ePTFE gafts. Ann Thorac Surg. (2001) 71:S327-S31. doi: 10.1016/S0003-4975(01)02555-3

216. Meinhart JG, Schense JC, Schima H, Gorlitzer M, Hubbell JA, Deutsch M, et al. Enhanced endothelial cell retention on shear-stressed synthetic vascular grafts precoated with RGD-cross-linked fibrin. Tissue Eng. (2005) 11:887-95. doi: $10.1089 /$ ten.2005.11.887

217. Fischlein T, Zilla P, Meinhart J, Puschmann R, Vesely M, Eberl T, et al. In vitro endothelialization of a mesosystemic shunt: a clinical case report. J Vasc Surg. (1994) 19:549-54. doi: 10.1016/S0741-5214(94)70084-2

218. Deutsch M, Meinhart J, Vesely M, Fischlein T, Groscurth P, von OU, et al. In vitro endothelialization of expanded polytetrafluoroethylene grafts: a clinical case report after 41 months of implantation. J Vasc Surg. (1997) 25:757-63. doi: 10.1016/S0741-5214(97)70307-0

219. Zilla P, Fullard L, Trescony P, Meinhart J, Bezuidenhout D, Gorlitzer M, et al. Glutaraldehyde detoxification of aortic wall tissue: a promising perspective for emerging bioprosthetic valve concepts. J Heart Valve Dis. (1997) 6:51020.

220. Grimm M, Eybl E, Grabenwoger M, Griesmacher A, Losert U, Bock P, et al. Biocompatibility of aldehyde-fixed bovine pericardium. An in vitro and in vivo approach toward improvement of bioprosthetic heart valves. $J$ Thorac Cardiovasc Surg. (1991) 102:195-201. doi: 10.1016/S0022-5223(19)36551-1

221. Grabenwoger M, Grimm M, Eybl E, Moritz A, Muller MM, Bock P, et al. Endothelial cell lining of bioprosthetic heart valve material. J Card Surg. (1992) 7:79-84. doi: 10.1111/j.1540-8191.1992.tb00778.x

222. Fischlein T, Lehner G, Lante W, Fittkau M, Murphy JG, Weinhold C, et al. Endothelialization of cardiac valve bioprostheses. Int J Artif Organs. (1994) 17:345-52. doi: 10.1177/039139889401700606

223. Eberl T, Siedler S, Schumacher B, Zilla P, Schlaudraff K, Fasol R. Experimental in vitro endothelialization of cardiac valve leaflets. Ann Thorac Surg. (1992) 53:487-92. doi: 10.1016/0003-4975(92)90275-9

224. Lehner G, Fischlein T, Baretton G, Murphy JG, Reichart B. Endothelialized biological heart valve prostheses in the non-human primate model. Eur J Cardiothorac Surg. (1997) 11:498-504. doi: 10.1016/S1010-7940(96)01096-2

225. Trantina-Yates AE, Human P, Bracher M, Zilla P. Mitigation of bioprosthetic heart valve degeneration through biocompatibility: in vitro versus spontaneous endothelialization. Biomaterials. (2001) 22:1837-46. doi: $10.1016 / \mathrm{S} 0142-9612(00) 00365-3$

226. Fischlein T, Fasol R. In vitro endothelialization of bioprosthetic heart valves. J Heart Valve Dis. (1996) 5:58-65.

227. Human P, Zilla P. The possible role of immune responses in bioprosthetic heart valve failure. J Heart Valve Dis. (2001) 10:460-6.

228. Human P, Zilla P. Characterization of the immune response to valve bioprostheses and its role in primary tissue failure. Ann Thorac Surg. (2001) 71 (5 Suppl):S385-8. doi: 10.1016/S0003-4975(01)02492-4

229. Human P, Zilla P. Inflammatory and immune processes: the neglected villain of bioprosthetic degeneration? J Long Term Eff Med Implants. 
(2001) 11:199-220. doi: 10.1615/JLongTermEffMedImplants.v11. i34.80

230. Katsimpoulas M, Morticelli L, Gontika I, Kouvaka A, Mallis P, Dipresa D, et al. Biocompatibility and immunogenicity of decellularized allogeneic aorta in the orthotopic rat model. Tissue Eng Part A. (2019) 25:399-415. doi: 10.1089/ten.tea.2018.0037

231. O'Brien MF, Goldstein S, Walsh S, Black KS, Elkins R, Clarke D. The SynerGraft valve: a new acellular (nonglutaraldehyde-fixed) tissue heart valve for autologous recellularization first experimental studies before clinical implantation. Semin Thorac Cardiovasc Surg. (1999) 11 (4 Suppl. 1):194-200.

232. Hawkins JA, Hillman ND, Lambert LM, Jones J, Di Russo GB, Profaizer T, et al. Immunogenicity of decellularized cryopreserved allografts in pediatric cardiac surgery: comparison with standard cryopreserved allografts. $J$ Thorac Cardiovasc Surg. (2003) 126:247-52. doi: 10.1016/S0022-5223(03) 00116-8

233. Elkins RC, Dawson PE, Goldstein S, Walsh SP, Black KS. Decellularized human valve allografts. Ann Thorac Surg. (2001) 71 (5 Suppl):S428-32. doi: 10.1016/S0003-4975(01)02503-6

234. Zilla P, Brink J, Human P, Bezuidenhout D. Prosthetic heart valves: catering for the few. Biomaterials. (2008) 29:385-406. doi: 10.1016/j.biomaterials.2007.09.033

235. Bezuidenhout D, Oosthuysen A, Human P, Weissenstein C, Zilla P. The effects of cross-link density and chemistry on the calcification potential of diamine-extended glutaraldehydefixed bioprosthetic heart-valve materials. Biotechnol Appl Biochem. (2009) 54:133-40. doi: 10.1042/BA20090101

236. Libby P, Birinyi LK. The dynamic nature of vascular endothelial function. In: Zilla PP, Fasol R, Deutsch M, editors. Endothelialization of Vascular Grafts. Basel: Karger (1987). p. 80-99.

237. Pober JS, Collins T, Gimbrone MA Jr, Libby P, Reiss CS. Inducible expression of class II major histocompatibility complex antigens and the immunogenicity of vascular endothelium. Transplantation. (1986) 41:141-6. doi: 10.1097/00007890-198602000-00001

238. Bevilacqua MP, Pober JS, Wheeler ME, Cotran RS, Gimbrone MA Jr. Interleukin 1 acts on cultured human vascular endothelium to increase the adhesion of polymorphonuclear leukocytes, monocytes, and related leukocyte cell lines. J Clin Invest. (1985) 76:2003-11. doi: 10.1172/JCI1 12200

239. Pober JS, Cotran RS. Cytokines and endothelial cell biology. Physiol Rev. (1990) 70:427-51. doi: 10.1152/physrev.1990.70.2.427

240. Teebken OE, Bader A, Steinhoff G, Haverich A. Tissue engineering of vascular grafts: human cell seeding of decellularised porcine matrix. Eur $J$ Vasc Endovasc Surg. (2000) 19:381-6. doi: 10.1053/ejvs.1999.1004

241. Stock UA, Schenke-Layland K. Performance of decellularized xenogeneic tissue in heart valve replacement. Biomaterials. (2006) 27:1-2. doi: 10.1016/j.biomaterials.2005.05.100

242. Bader A, Schilling T, Teebken O, Brandes G, Herden T, Steinhoff G, et al. Tissue engineering of heart valves-human endothelial cell seeding of detergent acellularized porcine valves. Eur J Cardiothorac Surg. (1998) 14:279-84. doi: 10.1016/S1010-7940(98)00171-7

243. Tudorache I, Calistru A, Baraki H, Meyer T, Hoffler K, Sarikouch S, et al. Orthotopic replacement of aortic heart valves with tissue-engineered grafts. Tissue Eng Part A. (2013) 19:1686-94. doi: 10.1089/ten.tea.2012.0074

244. Steinhoff G, Stock U, Karim N, Mertsching H, Timke A, Meliss RR, et al. Tissue engineering of pulmonary heart valves on allogenic acellular matrix conduits: in vivo restoration of valve tissue. Circulation. (2000) 102 (19 Suppl. 3):III50-5. doi: 10.1161/01.CIR.102.suppl_3.III-50

245. Lichtenberg A, Tudorache I, Cebotari S, Ringes-Lichtenberg S, Sturz G, Hoeffler K, et al. In vitro re-endothelialization of detergent decellularized heart valves under simulated physiological dynamic conditions. Biomaterials. (2006) 27:4221-9. doi: 10.1016/j.biomaterials.2006.03.047

246. Honge JL, Funder J, Hansen E, Dohmen PM, Konertz W, Hasenkam JM. Recellularization of aortic valves in pigs. Eur J Cardiothorac Surg. (2011) 39:829-34. doi: 10.1016/j.ejcts.2010.08.054

247. Leyh R, Wilhelmi M, Rebe P, Fischer S, Kofidis T, Haverich A, et al. In vivo repopulation of xenogeneic and allogeneic acellular valve matrix conduits in the pulmonary circulation. Ann Thorac Surg. (2003) 75:1457-63. doi: 10.1016/S0003-4975(02)04845-2
248. Dohmen PM, Ozaki S, Verbeken E, Yperman J, Flameng W, Konertz WF. Tissue engineering of an auto-xenograft pulmonary heart valve. Asian Cardiovasc Thorac Ann. (2002) 10:25-30. doi: 10.1177/021849230201000107

249. Dohmen PM, Ozaki S, Nitsch R, Yperman J, Flameng W, Konertz W. A tissue engineered heart valve implanted in a juvenile sheep model. Med Sci Monit. (2003) 9:97-104

250. Dohmen PM, Lembcke A, Holinski S, Pruss A, Konertz W. Ten years of clinical results with a tissue-engineered pulmonary valve. Ann Thorac Surg. (2011) 92:1308-14. doi: 10.1016/j.athoracsur.2011.06.009

251. Cebotari S, Tudorache I, Jaekel T, Hilfiker A, Dorfman S, Ternes W, et al. Detergent decellularization of heart valves for tissue engineering: toxicological effects of residual detergents on human endothelial cells. Artif Organs. (2010) 34:206-10. doi: 10.1111/j.1525-1594.2009.00796.x

252. Dohmen PM, Lembcke A, Hotz H, Kivelitz D, Konertz WF. Ross operation with a tissue-engineered heart valve. Ann Thorac Surg. (2002) 74:1438-42. doi: 10.1016/S0003-4975(02)03881-X

253. Cebotari S, Lichtenberg A, Tudorache I, Hilfiker A, Mertsching H, Leyh $\mathrm{R}$, et al. Clinical application of tissue engineered human heart valves using autologous progenitor cells. Circulation. (2006) 114 (1 Suppl):I132-7. doi: 10.1161/CIRCULATIONAHA.105.001065

254. Dohmen PM, Lembcke A, Holinski S, Kivelitz D, Braun JP, Pruss A, et al. Mid-term clinical results using a tissue-engineered pulmonary valve to reconstruct the right ventricular outflow tract during the ross procedure. Ann Thorac Surg. (2007) 84:729-36. doi: 10.1016/j.athoracsur.2007. 04.072

255. Theodoridis K, Tudorache I, Calistru A, Cebotari S, Meyer T, Sarikouch $S$, et al. Successful matrix guided tissue regeneration of decellularized pulmonary heart valve allografts in elderly sheep. Biomaterials. (2015) 52:221-8. doi: 10.1016/j.biomaterials.2015.02.023

256. Bobylev D, Breymann T, Boethig D, Haverich A, Ono M. Semilunar valve replacement with decellularized homograft after damus-kaye-stansel anastomosis and fontan procedure. Ann Thorac Surg. (2014) 97:1792-5. doi: 10.1016/j.athoracsur.2013.07.116

257. Gogolewski S, Pennings AJ, Lommen E, Wildevuur CR. Small-caliber biodegradable vascular grafts from Groningen. Life Support Syst. (1983) 1 (Suppl. 1):382-5

258. van der Lei B, Wildevuur CR, Nieuwenhuis P, Blaauw EH, Dijk F, Hulstaert $\mathrm{CE}$, et al. Regeneration of the arterial wall in microporous, compliant, biodegradable vascular grafts after implantation into the rat abdominal aorta. Ultrastructural observations. Cell Tissue Res. (1985) 242:569-78. doi: 10.1007/BF00225423

259. van der Lei B, Darius H, Schror K, Nieuwenhuis P, Molenaar I, Wildevuur CR. Arterial wall regeneration in small-caliber vascular grafts in rats. Neoendothelial healing and prostacyclin production. J Thorac Cardiovasc Surg. (1985) 90:378-86. doi: 10.1016/S0022-5223(19)38593-9

260. van der Lei B, Bartels HL, Nieuwenhuis P, Wildevuur CR. Microporous, complaint, biodegradable vascular grafts for the regeneration of the arterial wall in rat abdominal aorta. Surgery. (1985) 98:955-63.

261. Lommen E, Gogolewski S, Pennings AJ, Wildevuur CR, Nieuwenhuis P. Development of a neo-artery induced by a biodegradable polymeric vascular prosthesis. Trans Am Soc Artif Intern Organs. (1983) 29:255-9.

262. van Oene GH, Yue X, van der Lei B, Schakenraad JM, Kuit JH, Feijen J, et al. Smooth muscle cell seeding enhances neo-endothelialization. In: Zilla P, Fasol R, Deutsch M, editors. Endothelialization of Vascular Grafts. Basel: Karger (1987). p. 160-6.

263. Langer R, Vacanti JP. Tissue engineering. Science. (1993) 260:920-6. doi: 10.1126/science.8493529

264. Vacanti JP, Morse MA, Saltzman WM, Domb AJ, Perez-Atayde A, Langer R. Selective cell transplantation using bioabsorbable artificial polymers as matrices. J Pediatr Surg. (1988) 23:3-9. doi: 10.1016/S0022-3468(88) 80529-3

265. Vacanti CA, Langer R, Schloo B, Vacanti JP. Synthetic polymers seeded with chondrocytes provide a template for new cartilage formation. Plast Reconstr Surg. (1991) 88:753-9. doi: 10.1097/00006534-199111000-00001

266. Shinoka T, Shum-Tim D, Ma PX, Tanel RE, Isogai N, Langer R, et al. Creation of viable pulmonary artery autografts through tissue engineering. $J$ Thorac Cardiovasc Surg. (1998) 115:536-45. doi: 10.1016/S0022-5223(98)70315-0 
267. Shinoka T, Shum-Tim D, Ma PX, Tanel RE, Langer R, Vacanti JP, et al. Tissueengineered heart valve leaflets: does cell origin affect outcome? Circulation. (1997) 96 (9 Suppl):II102-7.

268. Kelm JM, Lorber V, Snedeker JG, Schmidt D, Broggini-Tenzer A, Weisstanner $\mathrm{M}$, et al. A novel concept for scaffold-free vessel tissue engineering: self-assembly of microtissue building blocks. J Biotechnol. (2010) 148:46-55. doi: 10.1016/j.jbiotec.2010.03.002

269. Weber B, Scherman J, Emmert MY, Gruenenfelder J, Verbeek R, Bracher $\mathrm{M}$, et al. Injectable living marrow stromal cell-based autologous tissue engineered heart valves: first experiences with a one-step intervention in primates. Eur Heart J. (2011) 32:2830-40. doi: 10.1093/eurheartj/ehr059

270. Lira OB. [Use of PGA(polyglycolic acid) sutures in general surgery]. Hospital. (1969) 75:1719-26.

271. Sodian R, Hoerstrup SP, Sperling JS, Daebritz SH, Martin DP, Schoen FJ, et al. Tissue engineering of heart valves: in vitro experiences. Ann Thorac Surg. (2000) 70:140-4. doi: 10.1016/S0003-4975(00)01255-8

272. Hoerstrup SP, Sodian R, Sperling JS, Vacanti JP, Mayer JE Jr. New pulsatile bioreactor for in vitro formation of tissue engineered heart valves. Tissue Eng. (2000) 6:75-9. doi: 10.1089/107632700320919

273. Hoerstrup SP, Sodian R, Daebritz S, Wang J, Bacha EA, Martin DP, et al. Functional living trileaflet heart valves grown in vitro. Circulation. (2000) 102 (19 Suppl. 3):III44-9. doi: 10.1161/01.CIR.102.suppl_3.III-44

274. Hoerstrup SP, Cummings Mrcs I, Lachat M, Schoen FJ, Jenni R, Leschka S, et al. Functional growth in tissue-engineered living, vascular grafts: follow-up at 100 weeks in a large animal model. Circulation. (2006) 114 (1 Suppl):I15966. doi: 10.1161/CIRCULATIONAHA.105.001172

275. Perry TE, Kaushal S, Sutherland FW, Guleserian KJ, Bischoff J, Sacks M, et al. Thoracic surgery directors association award. bone marrow as a cell source for tissue engineering heart valves. Ann Thorac Surg. (2003) 75:761-7. doi: 10.1016/S0003-4975(02)03776-1

276. Zund G, Breuer CK, Shinoka T, Ma PX, Langer R, Mayer JE, et al. The in vitro construction of a tissue engineered bioprosthetic heart valve. Eur J Cardiothorac Surg. (1997) 11:493-7. doi: 10.1016/S1010-7940(96)01005-6

277. Sutherland FW, Perry TE, Yu Y, Sherwood MC, Rabkin E, Masuda Y, et al. From stem cells to viable autologous semilunar heart valve. Circulation. (2005) 111:2783-91. doi: 10.1161/CIRCULATIONAHA.104.498378

278. Schmidt D, Breymann C, Weber A, Guenter CI, Neuenschwander S, Zund G, et al. Umbilical cord blood derived endothelial progenitor cells for tissue engineering of vascular grafts. Ann Thorac Surg. (2004) 78:2094-8. doi: 10.1016/j.athoracsur.2004.06.052

279. Schmidt D, Mol A, Breymann C, Achermann J, Odermatt B, Gossi $\mathrm{M}$, et al. Living autologous heart valves engineered from human prenatally harvested progenitors. Circulation. (2006) 114 (1 Suppl):I125-31. doi: 10.1161/CIRCULATIONAHA.105.001040

280. Generali M, Casanova EA, Kehl D, Wanner D, Hoerstrup SP, Cinelli P, et al. Autologous endothelialized small-caliber vascular grafts engineered from blood-derived induced pluripotent stem cells. Acta Biomater. (2019) 97:333-43. doi: 10.1016/j.actbio.2019.07.032

281. Goligorsky MS. New trends in regenerative medicine: reprogramming and reconditioning. J Am Soc Nephrol. (2019) 30:2047-51. doi: 10.1681/ASN.2019070722

282. Hoerstrup S, Zund G, Ye Q, Schoeberlein A, Schmid A, Turina M. Tissue engineering of a bioprosthetic heart valve: stimulation of extracellular matrix assessed by hydroxyproline assay. ASAIO J. (1999) 45:397-402. doi: 10.1097/00002480-199909000-00006

283. Mol A, Bouten CV, Zund G, Gunter CI, Visjager JF, Turina MI, et al. The relevance of large strains in functional tissue engineering of heart valves. Thorac Cardiovasc Surg. (2003) 51:78-83. doi: 10.1055/s-200338993

284. Roh JD, Brennan MP, Lopez-Soler RI, Fong PM, Goyal A, Dardik $A$, et al. Construction of an autologous tissue-engineered venous conduit from bone marrow-derived vascular cells: optimization of cell harvest and seeding techniques. J Pediatr Surg. (2007) 42:198-202. doi: 10.1016/j.jpedsurg.2006.09.054

285. Sundaram S, Echter A, Sivarapatna A, Qiu C, Niklason L. Smalldiameter vascular graft engineered using human embryonic stem cell-derived mesenchymal cells. Tissue Eng Part A. (2014) 20:740-50. doi: $10.1089 /$ ten.TEA.2012.0738
286. Mitchell S, Niklason L. Requirements for growing tissueengineered vascular grafts. Cardiovasc Pathol. (2003) 12:59-64. doi: 10.1016/S1054-8807(02)00183-7

287. L'Heureux N, Paquet S, Labbe R, Germain L, Auger F. A completely biological tissue-engineered human blood vessel. FASEB J. (1998) 12:47-56. doi: 10.1096/fsb2fasebj.12.1.47

288. McAllister TN, Maruszewski M, Garrido SA, Wystrychowski W, Dusserre $\mathrm{N}$, Marini A, et al. Effectiveness of haemodialysis access with an autologous tissue-engineered vascular graft: a multicentre cohort study. Lancet. (2009) 373:1440-6. doi: 10.1016/S0140-6736(09)60248-8

289. L'Heureux N, Dusserre N, Konig G, Victor B, Keire P, Wight TN, et al. Human tissue-engineered blood vessels for adult arterial revascularization. Nat Med. (2006) 12:361-5. doi: 10.1038/nm1364

290. L'Heureux N, Germain L, Labbe R, Auger FA. In vitro construction of a human blood vessel from cultured vascular cells: a morphologic study. J Vasc Surg. (1993) 17:499-509. doi: 10.1016/0741-5214(93)90150-K

291. Black AF, Berthod F, L'Heureux N, Germain L, Auger FA. In vitro reconstruction of a human capillary-like network in a tissue-engineered skin equivalent. FASEB J. (1998) 12:1331-40. doi: 10.1096/fasebj.12. 13.1331

292. Jang EH, Kim JH, Lee JH, Kim DH, Youn YN. Enhanced biocompatibility of multi-layered, 3D bio-printed artificial vessels composed of autologous mesenchymal stem cells. Polymers. (2020) 12:538-40. doi: $10.3390 /$ polym 12030538

293. Wystrychowski W, Cierpka L, Zagalski K, Garrido S, Dusserre N, Radochonski S, et al. Case study: first implantation of a frozen, devitalized tissue-engineered vascular graft for urgent hemodialysis access. J Vasc Access. (2011) 12:67-70. doi: 10.5301/JVA.2011.6360

294. Wystrychowski W, McAllister TN, Zagalski K, Dusserre N, Cierpka L, L'Heureux N. First human use of an allogeneic tissue-engineered vascular graft for hemodialysis access. J Vasc Surg. (2014) 60:1353-7. doi: 10.1016/j.jvs.2013.08.018

295. Badylak SF, Freytes DO, Gilbert TW. Extracellular matrix as a biological scaffold material: structure and function. Acta Biomater. (2009) 5:1-13. doi: 10.1016/j.actbio.2008.09.013

296. Courtman DW, Pereira CA, Kashef V, McComb D, Lee JM, Wilson GJ. Development of a pericardial acellular matrix biomaterial: biochemical and mechanical effects of cell extraction. J Biomed Mater Res. (1994) 28:655-66. doi: $10.1002 / \mathrm{jbm} .820280602$

297. Haupt J, Lutter G, Gorb SN, Simionescu DT, Frank D, Seiler J, et al. Detergent-based decellularization strategy preserves macro- and microstructure of heart valves. Interact Cardiovasc Thorac Surg. (2018) 26:230-6. doi: 10.1093/icvts/ivx316

298. Hogan P, Duplock L, Green M, Smith S, Gall KL, Frazer IH, et al. Human aortic valve allografts elicit a donor-specific immune response. J Thorac Cardiovasc Surg. (1996) 112:1260-6. doi: 10.1016/S0022-5223(96)70139-3

299. Dignan R, O'Brien M, Hogan P, Thornton A, Fowler K, Byrne D, et al. Aortic valve allograft structural deterioration is associated with a subset of antibodies to human leukocyte antigens. J Heart Valve Dis. (2003) 12:382-90.

300. Dignan R, O’Brien M, Hogan P, Passage J, Stephens F, Thornton A, et al. Influence of HLA matching and associated factors on aortic valve homograft function. J Heart Valve Dis. (2000) 9:504-11.

301. Helder MRK, Stoyles NJ, Tefft BJ, Hennessy RS, Hennessy RRC, Dyer R, et al. Xenoantigenicity of porcine decellularized valves. J Cardiothorac Surg. (2017) 12:56. doi: 10.1186/s13019-017-0621-5

302. Simon P, Kasimir M, Seebacher G, Weigel G, Ullrich R, Salzer $\mathrm{MU}$, et al. Early failure of the tissue engineered porcine heart valve SYNERGRAFT in pediatric patients. Eur J Cardiothorac Surg. (2003) 23:1002-6. doi: 10.1016/S1010-7940(03)00094-0

303. Koolbergen DR, Hazekamp MG, de Heer E, Bruggemans EF, Huysmans HA, Dion RA, et al. The pathology of fresh and cryopreserved homograft heart valves: an analysis of forty explanted homograft valves. J Thorac Cardiovasc Surg. (2002) 124:689-97. doi: 10.1067/mtc.2002.1 24514

304. Rabkin-Aikawa E, Aikawa M, Farber M, Kratz JR, Garcia-Cardena G, Kouchoukos NT, et al. Clinical pulmonary autograft valves: pathologic evidence of adaptive remodeling in the aortic site. J Thorac Cardiovasc Surg. (2004) 128:552-61. doi: 10.1016/j.jtcvs.2004.04.016 
305. Schoof PH, Takkenberg JJ, van Suylen RJ, Zondervan PE, Hazekamp MG, Dion RA, et al. Degeneration of the pulmonary autograft: an explant study. J Thorac Cardiovasc Surg. (2006) 132:1426-32. doi: 10.1016/j.jtcvs.2006.07.035

306. Tudorache I, Theodoridis K, Baraki H, Sarikouch S, Bara C, Meyer T, et al. Decellularized aortic allografts versus pulmonary autografts for aortic valve replacement in the growing sheep model: haemodynamic and morphological results at 20 months after implantation. Eur J Cardiothorac Surg. (2016) 49:1228-38. doi: 10.1093/ejcts/ezv362

307. Mitchell RN, Jonas RA, Schoen FJ. Pathology of explanted cryopreserved allograft heart valves: comparison with aortic valves from orthotopic heart transplants. J Thorac Cardiovasc Surg. (1998) 115:118-27. doi: 10.1016/S0022-5223(98)70450-7

308. VeDepo MC, Detamore MS, Hopkins RA, Converse GL. Recellularization of decellularized heart valves: progress toward the tissue-engineered heart valve. J Tissue Eng. (2017) 8:1-21. doi: 10.1177/2041731417726327

309. Sauvage LR, Berger K, Wood SJ, Nakagawa Y, Mansfield PB. An external velour surface for porous arterial prostheses. Surgery. (1971) 70:940-53.

310. CryoLife Inc. CryoLife Written Submission for Docket No. FDA-2014-N0001-0074. Silverspring, MD: Silver Spring MFaDA (2014).

311. van Rijswijk JW, Talacua H, Mulder K, van Hout GPJ, Bouten CVC, Grundeman PF, et al. Failure of decellularized porcine small intestinal submucosa as a heart valved conduit. J Thorac Cardiovasc Surg. (2020) 90:1854-60. doi: 10.1016/j.jtcvs.2019.09.164

312. Mosala Nezhad Z, Poncelet A, de Kerchove L, Gianello P, Fervaille C, El Khoury G. Small intestinal submucosa extracellular matrix (CorMatrix(R)) in cardiovascular surgery: a systematic review. Interact Cardiovasc Thorac Surg. (2016) 22:839-50. doi: 10.1093/icvts/ivw020

313. Kalra K, Padala M. Commentary: pouring life into dead tissues: a brief history of the porcine small intestine submucose (SIS) in cardiovascular surgery success, failures, hype and hope. J Thorac Cardiovasc Surg. (2020) 54:434-40. doi: 10.1016/j.jtcvs.2019.10.057

314. Fraser CD. Commentary: overpromised, understudied: the slippery slope of pediatric cardiac device development. J Thorac Cardiovasc Surg. (2020) 22:454-62. doi: 10.1016/j.jtcvs.2019.10.171

315. Sarikouch S, Horke A, Tudorache I, Beerbaum P, Westhoff-Bleck M, Boethig D, et al. Decellularized fresh homografts for pulmonary valve replacement: a decade of clinical experience. Eur J Cardiothorac Surg. (2016) 50:281-90. doi: 10.1093/ejcts/ezw050

316. da Costa FD, Costa AC, Prestes R, Domanski AC, Balbi EM, Ferreira AD, et al. The early and midterm function of decellularized aortic valve allografts. Ann Thorac Surg. (2010) 90:1854-60. doi: 10.1016/j.athoracsur.2010.08.022

317. Cebotari S, Tudorache I, Ciubotaru A, Boethig D, Sarikouch S, Goerler A, et al. Use of fresh decellularized allografts for pulmonary valve replacement may reduce the reoperation rate in children and young adults: early report. Circulation. (2011) 124 (11 Suppl):S115-23. doi: 10.1161/CIRCULATIONAHA.110.012161

318. Etnel JRG, Suss PH, Schnorr GM, Veloso M, Colatusso DF, Balbi Filho EM, et al. Fresh decellularized versus standard cryopreserved pulmonary allografts for right ventricular outflow tract reconstruction during the ross procedure: a propensity-matched study. Eur J Cardiothorac Surg. (2018) 54:434-40. doi: 10.1093/ejcts/ezy079

319. Costa F, Dohmen P, Vieira E, Lopes SV, Colatusso C, Pereira EW, et al. Ross Operation with decellularized pulmonary allografts: medium-term results. Rev Bras Cir Cardiovasc. (2007) 22:454-62. doi: $10.1590 / \mathrm{S} 0102-76382007000400012$

320. Brown JW, Ruzmetov M, Eltayeb O, Rodefeld MD, Turrentine MW. Performance of SynerGraft decellularized pulmonary homograft in patients undergoing a ross procedure. Ann Thorac Surg. (2011) 91:416-22 doi: 10.1016/j.athoracsur.2010.10.069

321. Wilson GJ, Yeger H, Klement P, Lee JM, Courtman DW. Acellular matrix allograft small caliber vascular prostheses. ASAIO Trans. (1990) 36:M340-3.

322. Dahl SLM, Koh J, Prabhakar V, Niklason LE. Decellularized native and engineered arterial scaffolds for transplantation. Cell Transplant. (2003) 12:659-66. doi: 10.3727/000000003108747136

323. Dahl SL, Kypson AP, Lawson JH, Blum JL, Strader JT, Li Y, et al. Readily available tissue-engineered vascular grafts. Sci Transl Med. (2011) 3:68-9. doi: $10.1126 /$ scitranslmed. 3001426
324. Quint C, Arief M, Muto A, Dardik A, Niklason LE. Allogeneic human tissue-engineered blood vessel. J Vasc Surg. (2012) 55:790-8. doi: 10.1016/j.jvs.2011.07.098

325. Lawson JH, Glickman MH, Ilzecki M, Jakimowicz T, Jaroszynski A, Peden EK, et al. Bioengineered human acellular vessels for dialysis access in patients with end-stage renal disease: two phase 2 single-arm trials. Lancet. (2016) 387:2026-34. doi: 10.1016/S0140-6736(16)00557-2

326. Kirkton RD, Santiago-Maysonet M, Lawson JH, Tente WE, Dahl SLM, Niklason LE, et al. Bioengineered human acellular vessels recellularize and evolve into living blood vessels after human implantation. Sci Transl Med. (2019) 11eaau5834. doi: 10.1126/scitranslmed.aau6934

327. Gutowski P, Gage SM, Guziewicz M, Ilzecki M, Kazimierczak A, Kirkton $\mathrm{RD}$, et al. Arterial reconstruction with human bioengineered acellular blood vessels in patients with peripheral arterial disease. J Vasc Surg. (2020) 11:47082. doi: $10.1016 /$ j.jvs.2019.11.056

328. Grabenwoger M, Fitzal F, Sider J, Cseko C, Bergmeister H, Schima $\mathrm{H}$, et al. Endothelialization of biosynthetic vascular prostheses after laser perforation. Ann Thorac Surg. (1998) 66 (6 Suppl):S110-4. doi: 10.1016/S0003-4975(98)00982-5

329. Bergmeister H, Boeck P, Kasimir MT, Fleck T, Fitzal F, Husinsky $\mathrm{W}$, et al. Effect of laser perforation on the remodeling of acellular matrix grafts. J Biomed Mater Res B Appl Biomater. (2005) 74:495-503. doi: $10.1002 / j$ bm.b. 30228

330. Laufer G, Wollenek G, Rueckle B, Buchelt M, Kuckla C, Ruatti H, et al. Characteristics of $308 \mathrm{~nm}$ excimer laser activated arterial tissue photoemission under ablative and non-ablative conditions. Lasers Surg Med. (1989) 9:556-71. doi: 10.1002/lsm.1900090605

331. Doi K, Nakayama Y, Matsuda T. Novel compliant and tissue-permeable microporous polyurethane vascular prosthesis fabricated using an excimer laser ablation technique. J Biomed Mater Res. (1996) 31:27-33. doi: 10.1002/(SICI)1097-4636(199605)31:1<27::AID-JBM4>3.0.CO;2-S

332. Matsuda T, Nakayama Y. Surface microarchitectural design in biomedical applications: in vitro transmural endothelialization on microporous segmented polyurethane films fabricated using an excimer laser. $J$ Biomed Mater Res. (1996) 31:235-42. doi: 10.1002/(SICI)1097-4636(199606)31:2<235::AID-JBM10>3.0.CO;2-K

333. Magnan L, Labrunie G, Fenelon M, Dusserre N, Foulc MP, Lafourcade M, et al. Human textiles: a cell-synthesized yarn as a truly "bio" material for tissue engineering applications. Acta Biomater. (2020) 105:111-20. doi: 10.1016/j.actbio.2020.01.037

334. Syedain ZH, Graham ML, Dunn TB, O'Brien T, Johnson SL, Schumacher RJ, et al. A completely biological "off-the-shelf" arteriovenous graft that recellularizes in baboons. Sci Transl Med. (2017) 9:eaan4209. doi: 10.1126/scitranslmed.aan4209

335. Weber B, Dijkman PE, Scherman J, Sanders B, Emmert MY, Grunenfelder $\mathrm{J}$, et al. Off-the-shelf human decellularized tissue-engineered heart valves in a non-human primate model. Biomaterials. (2013) 34:7269-80. doi: 10.1016/j.biomaterials.2013.04.059

336. Spriestersbach H, Prudlo A, Bartosch M, Sanders B, Radtke T, Baaijens FP, et al. First percutaneous implantation of a completely tissue-engineered self-expanding pulmonary heart valve prosthesis using a newly developed delivery system: a feasibility study in sheep. Cardiovasc Interv Ther. (2017) 32:36-47. doi: 10.1007/s12928-016-0396-y

337. Motta SE, Lintas V, Fioretta ES, Dijkman PE, Putti M, Caliskan E, et al. Human cell-derived tissue-engineered heart valve with integrated valsalva sinuses: towards native-like transcatheter pulmonary valve replacements. NPJ Regen Med. (2019) 4:14. doi: 10.1038/s41536-019-0077-4

338. Driessen-Mol A, Emmert MY, Dijkman PE, Frese L, Sanders B, Weber B, et al. Transcatheter implantation of homologous "off-the-shelf" tissueengineered heart valves with self-repair capacity: long-term functionality and rapid in vivo remodeling in sheep. J Am Coll Cardiol. (2014) 63:1320-9. doi: 10.1016/j.jacc.2013.09.082

339. Lintas V, Fioretta ES, Motta SE, Dijkman PE, Pensalfini M, Mazza E, et al. Development of a novel human cell-derived tissue-engineered heart valve for transcatheter aortic valve replacement: an in vitro and in vivo feasibility study. J Cardiovasc Transl Res. (2018) 11:470-82. doi: 10.1007/s12265-018-9821-1 
340. Sanders B, Loerakker S, Fioretta ES, Bax DJ, Driessen-Mol A, Hoerstrup $\mathrm{SP}$, et al. Improved geometry of decellularized tissue engineered heart valves to prevent leaflet retraction. Ann Biomed Eng. (2016) 44:1061-71. doi: 10.1007/s10439-015-1386-4

341. Syedain Z, Reimer J, Schmidt J, Lahti M, Berry J, Bianco R, et al. 6-month aortic valve implantation of an off-the-shelf tissue-engineered valve in sheep. Biomaterials. (2015) 73:175-84. doi: 10.1016/j.biomaterials.2015.09.016

342. Sauvage LR, Berger K, Beilin LB, Smith JC, Wood SJ, Mansfield PB. Presence of endothelium in an axillary-femoral graft of knitted dacron with an external velour surface. Ann Surg. (1975) 182:749-53. doi: 10.1097/00000658-197512000-00017

343. Chantre CO, Gonzalez GM, Ahn S, Cera L, Campbell PH, Hoerstrup SP, et al. Porous biomimetic hyaluronic acid and extracellular matrix protein nanofiber scaffolds for accelerated cutaneous tissue repair. ACS Appl Mater Interfaces. (2019) 11:45498-510. doi: 10.1021/acsami.9b17322

344. Rice JJ, Martino MM, De Laporte L, Tortelli F, Briquez PS, Hubbell JA. Engineering the regenerative microenvironment with biomaterials. Adv Healthc Mater. (2013) 2:57-71. doi: 10.1002/adhm.201200197

345. Chantre CO, Hoerstrup SP, Parker KK. Engineering biomimetic and instructive materials for wound healing and regeneration. Curr Opin Biomed Eng. (2019) 10:97-106. doi: 10.1016/j.cobme.2019.04.004

346. Zhang Z, Marois Y, Guidoin RG, Bull P, Marois M, How T, et al. Vascugraft polyurethane arterial prosthesis as femoro-popliteal and femoro-peroneal bypasses in humans: pathological, structural and chemical analyses of four excised grafts. Biomaterials. (1997) 18:113-24. doi: 10.1016/S0142-9612(96)00054-3

347. Shi Q, Wu MH, Fujita Y, Ishida A, Wijelath ES, Hammond WP, et al. Genetic tracing of arterial graft flow surface endothelialization in allogeneic marrow transplanted dogs. Cardiovasc Surg. (1999) 7:98-105. doi: 10.1016/S0967-2109(98)00027-1

348. Asahara T, Murohara T, Sullivan A, Silver M, van der Zee R, Li T, et al. Isolation of putative progenitor endothelial cells for angiogenesis. Science. (1997) 275:964-7. doi: 10.1126/science.275.5302.964

349. Rotmans JI, Heyligers JM, Verhagen HJ, Velema E, Nagtegaal MM, de Kleijn DP, et al. In vivo cell seeding with anti-CD34 antibodies successfully accelerates endothelialization but stimulates intimal hyperplasia in porcine arteriovenous expanded polytetrafluoroethylene grafts. Circulation. (2005) 112:12-8. doi: 10.1161/CIRCULATIONAHA.104.504407

350. Serrano MC, Pagani R, Ameer GA, Vallet-Regi M, Portoles MT. Endothelial cells derived from circulating progenitors as an effective source to functional endothelialization of $\mathrm{NaOH}$-treated poly(epsilon-caprolactone) films. $J$ Biomed Mater Res A. (2008) 87:964-71. doi: 10.1002/jbm.a.31728

351. Maeda M, Fukui A, Nakamura T, Inada Y, Tamai S, Haga S, et al. Progenitor endothelial cells on vascular grafts: an ultrastructural study. J Biomed Mater Res. (2000) 51:55-60. doi: 10.1002/(SICI)1097-4636(200007)51:1<55::AIDJBM8>3.0.CO;2-R

352. Co M, Tay E, Lee CH, Poh KK, Low A, Lim J, et al. Use of endothelial progenitor cell capture stent (genous bio-engineered $r$ stent) during primary percutaneous coronary intervention in acute myocardial infarction: intermediate- to long-term clinical follow-up. Am Heart J. (2008) 155:12832. doi: 10.1016/j.ahj.2007.08.031

353. Mrowczynski W, Rungatscher A, Buchegger F, Tille JC, Namy S, Ratib O, et al. Biological effects of anti-CD34-coated ePTFE vascular grafts. Early in vivo experimental results. Kardiochir Torakochirurgia Pol. (2014) 11:182-90. doi: 10.5114/kitp.2014.43848

354. Issa Bhaloo $\mathrm{S}$, $\mathrm{Wu} \mathrm{Y}$, Le Bras $\mathrm{A}, \mathrm{Yu} \mathrm{B}, \mathrm{Gu} \mathrm{W}$, Xie $\mathrm{Y}$, et al. Binding of dickkopf-3 to CXCR7 enhances vascular progenitor cell migration and degradable graft regeneration. Circ Res. (2018) 123:451-66. doi: 10.1161/CIRCRESAHA.118.312945

355. Chen L, He H, Wang M, Li X, Yin $H$. Surface coating of polytetrafluoroethylene with extracellular matrix and anti-CD34 antibodies facilitates endothelialization and inhibits platelet adhesion under sheer stress. Tissue Eng Regen Med. (2017) 14:359-70. doi: 10.1007/s13770-0170044-3

356. Davids L. The lack of healing in conventional vascular grafts. In: Zilla P, editor. Tissue Engineering of Vascular Prosthetic Grafts. Austin: RG.Landers (1999). p. 3-44.
357. Bezuidenhout D, Davies N, Zilla P. Effect of well-defined dodecahedral porosity on inflammation and angiogenesis. ASAIO J. (2002) 48:465-71. doi: 10.1097/00002480-200209000-00004

358. Wu J, Hong Y. Enhancing cell infiltration of electrospun fibrous scaffolds in tissue regeneration. Bioact Mater. (2016) 1:56-64. doi: 10.1016/j.bioactmat.2016.07.001

359. Voorneveld J, Oosthuysen A, Franz T, Zilla P, Bezuidenhout D. Dua electrospinning with sacrificial fibers for engineered porosity and enhancement of tissue ingrowth. J Biomed Mater Res B Appl Biomater. (2017) 105:1559-72. doi: 10.1002/jbm.b.33695

360. Szentivanyi A, Chakradeo T, Zernetsch H, Glasmacher B. Electrospun cellular microenvironments: understanding controlled release and scaffold structure. Adv Drug Deliv Rev. (2011) 63:209-20. doi: 10.1016/j.addr.2010.12.002

361. Schmidt C, Bezuidenhout D, Beck M, Van der Merwe E, Zilla P, Davies $\mathrm{N}$. Rapid three-dimensional quantification of VEGF-induced scaffold neovascularisation by microcomputed tomography. Biomaterials. (2009) 30:5959-68. doi: 10.1016/j.biomaterials.2009.07.044

362. Wronska MA, O'Connor IB, Tilbury MA, Srivastava A, Wall JG. Adding Functions to biomaterial surfaces through protein incorporation. Adv Mater. (2016) 28:5485-508. doi: 10.1002/adma.201504310

363. Adipurnama I, Yang MC, Ciach T, Butruk-Raszeja B. Surface modification and endothelialization of polyurethane for vascular tissue engineering applications: a review. Biomater Sci. (2016) 5:22-37. doi: 10.1039/C6BM00618C

364. Nguyen EB, Zilla P, Bezuidenhout D. Nitric oxide release from polydimethylsiloxane-based polyurethanes. J Appl Biomater Funct Mater. (2014) 12:172-82. doi: 10.5301/jabfm.5000192

365. Janjic M, Pappa F, Karagkiozaki V, Gitas C, Ktenidis K, Logothetidis S. Surface modification of endovascular stents with rosuvastatin and heparinloaded biodegradable nanofibers by electrospinning. Int J Nanomedicine. (2017) 12:6343-55. doi: 10.2147/IJN.S138261

366. Davies NH, Schmidt C, Bezuidenhout D, Zilla P. Sustaining neovascularization of a scaffold through staged release of vascular endothelial growth factor-A and platelet-derived growth factor-BB. Tissue Eng Part A. (2012) 18:26-34. doi: 10.1089/ten.tea.2011.0192

367. Davies N, Dobner S, Bezuidenhout D, Schmidt C, Beck M, Zisch AH, et al. The dosage dependence of VEGF stimulation on scaffold neovascularisation. Biomaterials. (2008) 29:3531-8. doi: 10.1016/j.biomaterials.2008. 05.007

368. Bezuidenhout D, Davies N, Black M, Schmidt C, Oosthuysen A, Zilla P. Covalent surface heparinization potentiates porous polyurethane scaffold vascularization. J Biomater Appl. (2010) 24:401-18. doi: 10.1177/0885328208097565

369. Reidy MA, Chao SS, Kirkman TR, Clowes AW. Endothelial regeneration. VI. Chronic nondenuding injury in baboon vascular grafts. Am J Pathol. (1986) 123:432-9.

370. Kohler T, Stratton J, Kirkman T, Johansen K, Zierler B, Clowes A. Conventional versus high-porosity polytetrafluoroethylene grafts: clinical evaluation. Surgery. (1992) 112:901-7.

371. Wissing TB, Bonito V, Bouten CVC, Smits A. Biomaterial-driven in situ cardiovascular tissue engineering-a multi-disciplinary perspective. NPJ Regen Med. (2017) 2:18. doi: 10.1038/s41536-017-0023-2

372. Sparks CH. Die-grown reinforced arterial grafts: observations on longterm animal grafts and clinical experience. Ann Surg. (1970) 172:787-94. doi: 10.1097/00000658-197011000-00003

373. Schoen FJ, Normann SJ, Brunswick RA, Diacoff GR. Can a small blood vessel prosthesis be derived from heterologous foreign body reactive tissue? J Biomed Mater Res. (1979) 13:149-54. doi: 10.1002/jbm.820130115

374. Hibing N, Yi T, Duncan DR, Rathore A, Dean E, Naito Y, et al. A critical role for macrophages in neovessel formation and the development of stenoses in tissue engineered vascular grafts. FASEB J. (2011) 25:4253-63. doi: 10.1096/fj.11-186585

375. Inoguchi $\mathrm{H}$, Kwon IK, Inoue E, Takamizawa K, Maehara Y, Matsuda T. Mechanical responses of a compliant electrospun poly(L-lactide-co-epsiloncaprolactone) small-diameter vascular graft. Biomaterials. (2006) 27:1470-8. doi: 10.1016/j.biomaterials.2005.08.029 
376. Liakouli V, Cipriani P, Di Benedetto P, Ruscitti P, Carubbi F, Berardicurti $\mathrm{O}$, et al. The role of extracellular matrix components in angiogenesis and fibrosis: possible implication for Systemic Sclerosis. Mod Rheumatol. (2018) 28:922-32. doi: 10.1080/14397595.2018.1431004

377. Stowell CET, Wang Y. Quickening: translational design of resorbable synthetic vascular grafts. Biomaterials. (2018) 173:71-86. doi: 10.1016/j.biomaterials.2018.05.006

378. Visvanathan P, Ondeck MG, Chirasatitsin S, Ngamkham K, Reilly GC, Engler AJ, et al. 3D surface topography guides stem cell adhesion and differentiation. Biomaterials. (2015) 52:140-7. doi: 10.1016/j.biomaterials.2015.01.034

379. Kluin J, Talacua H, Smits AI, Emmert MY, Brugmans MC, Fioretta ES, et al. In situ heart valve tissue engineering using a bioresorbable elastomeric implant - From material design to 12 months follow-up in sheep. Biomaterials. (2017) 125:101-17. doi: 10.1016/j.biomaterials.2017. 02.007

380. Hong Y, Ye SH, Nieponice A, Soletti L, Vorp DA, Wagner WR. A small diameter, fibrous vascular conduit generated from a poly(ester urethane)urea and phospholipid polymer blend. Biomaterials. (2009) 30:2457-67. doi: 10.1016/j.biomaterials.2009.01.013

381. Greisler HP, Kim DU, Price JB, Voorhees AB Jr. Arterial regenerative activity after prosthetic implantation. Arch Surg. (1985) 120:315-23. doi: 10.1001/archsurg.1985.01390270055010

382. Greisler HP. Arterial regeneration over absorbable prostheses. Arch Surg. (1982) 117:1425-31. doi: 10.1001/archsurg.1982.01380350029005

383. Galletti PM, Aebischer P, Sasken HF, Goddard MB, Chiu TH. Experience with fully bioresorbable aortic grafts in the dog. Surgery. (1988) 103:231-41.

384. Greisler HP, Tattersall CW, Klosak JJ, Cabusao EA, Garfield JD, Kim DU. Partially bioresorbable vascular grafts in dogs. Surgery. (1991) 110:645-54

385. Tanaka K, Fukuda D, Higashikuni Y, Hirata Y, Komuro I, Saotome $\mathrm{T}$, et al. Biodegradable extremely-small-diameter vascular graft made of silk fibroin can be implanted in mice. J Atheroscler Thromb. (2020). doi: $10.5551 /$ jat. 52720

386. Brugmans M, Serrero A, Cox M, Svanidze O, Schoen FJ. Morphology and mechanisms of a novel absorbable polymeric conduit in the pulmonary circulation of sheep. Cardiovasc Pathol. (2019) 38:31-8. doi: 10.1016/j.carpath.2018.10.008

387. Fukunishi T, Best CA, Sugiura T, Opfermann J, Ong CS, Shinoka T, et al. Preclinical study of patient-specific cell-free nanofiber tissue-engineered vascular grafts using 3-dimensional printing in a sheep model. J Thorac Cardiovasc Surg. (2017) 153:924-32. doi: 10.1016/j.jtcvs.2016.10.066

388. Zavan B, Vindigni V, Lepidi S, Iacopetti I, Avruscio G, Abatangelo G, et al. Neoarteries grown in vivo using a tissue-engineered hyaluronan-based scaffold. FASEB J. (2008) 22:2853-61. doi: 10.1096/fj.08-107284

389. Bowald S, Busch C, Eriksson I. Arterial regeneration following polyglactin 910 suture mesh grafting. Surgery. (1979) 86:722-9.

390. Mrowczynski W, Mugnai D, de Valence S, Tille JC, Khabiri E, Cikirikcioglu $\mathrm{M}$, et al. Porcine carotid artery replacement with biodegradable electrospun poly-e-caprolactone vascular prosthesis. J Vasc Surg. (2014) 59:210-9. doi: 10.1016/j.jvs.2013.03.004

391. Wisse E, Spiering AJ, van Leeuwen EN, Renken RA, Dankers PY, Brouwer LA, et al. Molecular recognition in poly(epsilon-caprolactone)based thermoplastic elastomers. Biomacromolecules. (2006) 7:3385-95. doi: 10.1021/bm060688t

392. Bennink G, Mroczek T, Sivalingam S, Prodan Z, Herrington C, Bacha E, et al. A novel pulmonary valve homing device - early feasibility study (EFSUS) and first in man (FIM-EU/Asia) one and two-year results. In: Bouten C, Takkenberg H, Smits A, Hjortnaes J, editors. 2nd International Confer-ence of Tissue engineered Heart Valves February 14th 2020. Abu Dhabi (2020):37-8.

393. Bockeria LA, Svanidze O, Kim A, Shatalov K, Makarenko V, Cox M, et al. Total cavopulmonary connection with a new bioabsorbable vascular graft: first clinical experience. J Thorac Cardiovasc Surg. (2017) 153:1542-50. doi: 10.1016/j.jtcvs.2016.11.071

394. Milleret V, Hefti T, Hall H, Vogel V, Eberli D. Influence of the fiber diameter and surface roughness of electrospun vascular grafts on blood activation. Acta Biomater. (2012) 8:4349-56. doi: 10.1016/j.actbio.2012.07.032

395. Patel HN, Thai KN, Chowdhury S, Singh R, Vohra YK, Thomas $\mathrm{V}$. In vitro degradation and cell attachment studies of a new electrospun polymeric tubular graft. Prog Biomater. (2015) 4:67-76. doi: 10.1007/s40204-015-0038-y

396. Pan Y, Zhou X, Wei Y, Zhang Q, Wang T, Zhu M, et al. Small-diameter hybrid vascular grafts composed of polycaprolactone and polydioxanone fibers. Sci Rep. (2017) 7:3615. doi: 10.1038/s41598-017-03851-1

397. Zhang X, Shi J, Chen S, Dong Y, Zhang L, Midgley AC, et al. Polycaprolactone/gelatin degradable vascular grafts simulating endothelium functions modified by nitric oxide generation. Regen Med. (2019) 14:1089105. doi: 10.2217/rme-2019-0015

398. van Almen GC, Talacua $\mathrm{H}$, Ippel $\mathrm{BD}$, Mollet BB, Ramaekers $\mathrm{M}$, Simonet $\mathrm{M}$, et al. Development of non-cell adhesive vascular grafts using supramolecular building blocks. Macromol Biosci. (2016) 16:350-62. doi: 10.1002/mabi.201500278

399. Li CY, Hu MH, Hu JJ. Use of aligned microscale sacrificial fibers in creating biomimetic, anisotropic poly(glycerol sebacate) scaffolds. Polymers. (2019) 11:1492. doi: 10.3390/polym11091492

400. Lee SE, Park YS. The role of bacterial cellulose in artificial blood vessels. $\mathrm{Mol}$ Cell Toxicol. (2017) 13:257-61. doi: 10.1007/s13273-017-0028-3

401. Zahedmanesh H, Mackle JN, Sellborn A, Drotz K, Bodin A, Gatenholm $\mathrm{P}$, et al. Bacterial cellulose as a potential vascular graft: mechanical characterization and constitutive model development. J Biomed Mater Res B Appl Biomater. (2011) 97:105-13. doi: 10.1002/jbm.b.31791

402. Scherner M, Reutter S, Klemm D, Sterner-Kock A, Guschlbauer M, Richter $\mathrm{T}$, et al. In vivo application of tissue-engineered blood vessels of bacterial cellulose as small arterial substitutes: proof of concept? J Surg Res. (2014) 189:340-7. doi: 10.1016/j.jss.2014.02.011

403. Gupta P, Lorentz KL, Haskett DG, Cunnane EM, Ramaswamy AK, Weinbaum JS, et al. Bioresorbable silk grafts for small diameter vascular tissue engineering applications: in vitro and in vivo functional analysis. Acta Biomater. (2020) 105:146-58. doi: 10.1016/j.actbio.2020.01.020

404. Copes F, Pien N, Van Vlierberghe S, Boccafoschi F, Mantovani D. CollagenBased tissue engineering strategies for vascular medicine. Front Bioeng Biotechnol. (2019) 7:166. doi: 10.3389/fbioe.2019.00166

405. McKenna KA, Hinds MT, Sarao RC, Wu PC, Maslen CL, Glanville RW, et al. Mechanical property characterization of electrospun recombinant human tropoelastin for vascular graft biomaterials. Acta Biomater. (2012) 8:225-33. doi: 10.1016/j.actbio.2011.08.001

406. Fernandez-Colino A, Wolf F, Rutten S, Schmitz-Rode T, Rodriguez-Cabello JC, Jockenhoevel S, et al. Small caliber compliant vascular grafts based on elastin-like recombinamers for in situ tissue engineering. Front Bioeng Biotechnol. (2019) 7:340. doi: 10.3389/fbioe.2019.00340

407. Aper T, Teebken OE, Steinhoff G, Haverich A. Use of a fibrin preparation in the engineering of a vascular graft model. Eur J Vasc Endovasc Surg. (2004) 28:296-302. doi: 10.1016/j.ejvs.2004.05.016

408. Koens MJ, Krasznai AG, Hanssen AE, Hendriks T, Praster R, Daamen WF, et al. Vascular replacement using a layered elastin-collagen vascular graft in a porcine model: one week patency versus one month occlusion. Organogenesis. (2015) 11:105-21. doi: 10.1080/15476278.2015.1038448

409. Antonova LV, Sevostyanova VV, Kutikhin AG, Mironov AV, Krivkina EO, Shabaev AR, et al. Vascular endothelial growth factor improves physico-mechanical properties and enhances endothelialization of poly(3-hydroxybutyrate-co-3-hydroxyvalerate)/poly(epsilon-caprolactone) small-diameter vascular grafts in vivo. Front Pharmacol. (2016) 7:230. doi: 10.3389/fphar.2016.00230

410. Ardila DC, Tamimi E, Doetschman T, Wagner WR, Vande Geest JP. Modulating smooth muscle cell response by the release of TGFbeta2 from tubular scaffolds for vascular tissue engineering. J Control Release. (2019) 299: 44-52. doi: 10.1016/j.jconrel.2019.02.024

411. Muylaert DE, van Almen GC, Talacua H, Fledderus JO, Kluin J, Hendrikse SI, et al. Early in-situ cellularization of a supramolecular vascular graft is modified by synthetic stromal cell-derived factor-1alpha derived peptides. Biomaterials. (2016) 76:187-95. doi: 10.1016/j.biomaterials.2015.10.052

412. Washington KS, Bashur CA. Delivery of antioxidant and anti-inflammatory agents for tissue engineered vascular grafts. Front Pharmacol. (2017) 8:659. doi: 10.3389/fphar.2017.00659

413. Freudenberg U, Liang Y, Kiick KL, Werner C. Glycosaminoglycanbased biohybrid hydrogels: a sweet and smart choice for multifunctional 
biomaterials. Adv Mater. (2016) 28:8861-91. doi: 10.1002/adma.2016 01908

414. Aper T, Wilhelmi M, Gebhardt C, Hoeffler K, Benecke N, Hilfiker A, et al. Novel method for the generation of tissue-engineered vascular grafts based on a highly compacted fibrin matrix. Acta Biomater. (2016) 29:21-32. doi: 10.1016/j.actbio.2015.10.012

415. Raeber GP, Lutolf MP, Hubbell JA. Molecularly engineered PEG hydrogels: a novel model system for proteolytically mediated cell migration. Biophys J. (2005) 89:1374-88. doi: 10.1529/biophysj.104.050682

416. Schmidt C, Bezuidenhout D, Zilla P, Davies NH. A slow-release fibrin matrix increases adeno-associated virus transduction of wound repair cells in vivo. $J$ Biomater Appl. (2014) 28:1408-18. doi: 10.1177/0885328213510331

417. Merzkirch C, Davies N, Zilla P. Engineering of vascular ingrowth matrices: are protein domains an alternative to peptides? Anat Rec. (2001) 263:379-87. doi: 10.1002/ar.1118

418. Lutolf MP, Lauer-Fields JL, Schmoekel HG, Metters AT, Weber FE, Fields GB, et al. Synthetic matrix metalloproteinase-sensitive hydrogels for the conduction of tissue regeneration: engineering cell-invasion characteristics. Proc Natl Acad Sci USA. (2003) 100:5413-8. doi: 10.1073/pnas.07373 81100

419. Liu J, Zheng H, Poh PS, Machens HG, Schilling AF. Hydrogels for engineering of perfusable vascular networks. Int J Mol Sci. (2015) 16:159976016. doi: 10.3390/ijms160715997

420. Janse van Rensburg A, Davies NH, Oosthuysen A, Chokoza C, Zilla $\mathrm{P}$, Bezuidenhout D. Improved vascularization of porous scaffolds through growth factor delivery from heparinized polyethylene glycol hydrogels. Acta Biomater. (2017) 49:89-100. doi: 10.1016/j.actbio.2016. 11.036

421. Goetsch KP, Bracher M, Bezuidenhout D, Zilla P, Davies NH. Regulation of tissue ingrowth into proteolytically degradable hydrogels. Acta Biomater. (2015) 24:44-52. doi: 10.1016/j.actbio.2015.06.009

422. Zisch AH, Lutolf MP, Ehrbar M, Raeber GP, Rizzi SC, Davies N, et al. Cell-demanded release of VEGF from synthetic, biointeractive cell ingrowth matrices for vascularized tissue growth. Faseb J. (2003) 17:2260-2. doi: 10.1096/fj.02-1041fje

423. Bracher M, Bezuidenhout D, Lutolf MP, Franz T, Sun M, Zilla P, et al. Cell specific ingrowth hydrogels. Biomaterials. (2013) 34:6797-803. doi: 10.1016/j.biomaterials.2013.05.057

Conflict of Interest: The authors declare that the research was conducted in the absence of any commercial or financial relationships that could be construed as a potential conflict of interest.

Copyright (C) 2020 Zilla, Deutsch, Bezuidenhout, Davies and Pennel. This is an openaccess article distributed under the terms of the Creative Commons Attribution License (CC BY). The use, distribution or reproduction in other forums is permitted, provided the original author(s) and the copyright owner(s) are credited and that the original publication in this journal is cited, in accordance with accepted academic practice. No use, distribution or reproduction is permitted which does not comply with these terms. 